برنامج مقترح قائم على نموذج فراير لتنمية المفاهيم المنطقية الأساسية

و الكفاءة الذاتية المدركة ويقاء أثر التعلم لاى الطالبات المعلمات شعبة فلسفة وإجتماع

$$
\text { د/ صباح أمين على }
$$

مدرس بكلية البنات بقسم المناهج وطرق التدريس - جامعة عين شمس 


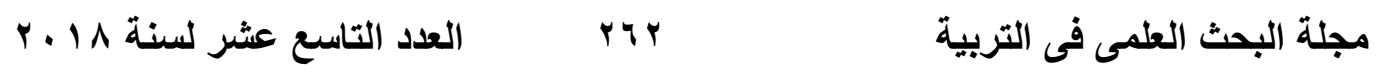

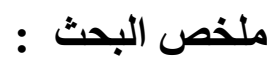

يهاف هذا البحث إلى الكثف عن مدى فاعلية برنامج مقترح قائم على نموذج فراير لتنمية

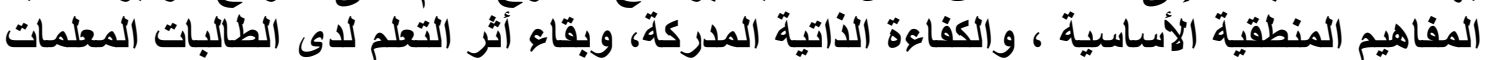
شعبة فلسفة وإجتماع الاعناع.

$$
\text { ولتحقيق هذا الهدف أعدت الباحثة الأدوات التالية : }
$$

أ- أدوات التجريب : وتتمثل في البرنامج المقترح في ضوء نموذج فراير ( دليل المعلم ،

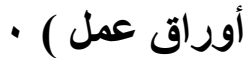
بـ أدوات القياس : وتثثمل اختبار في المفاهيم المنطقية الأساسية ــ مقياس الكفاعة الذاتية.

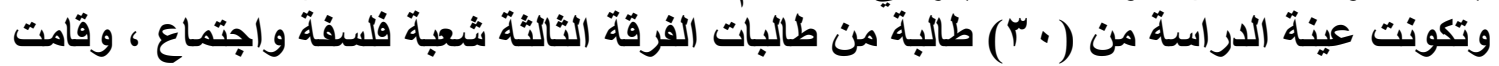

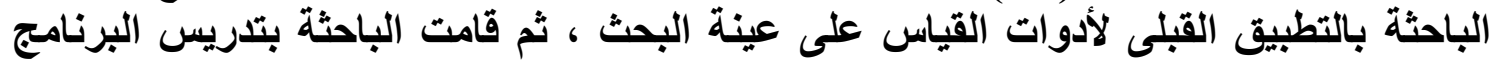

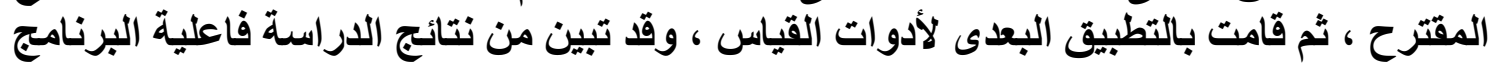

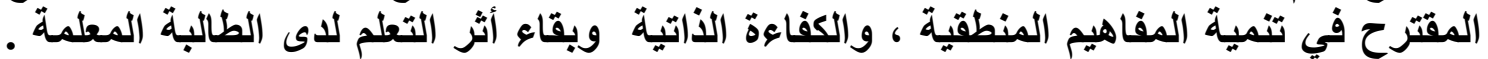

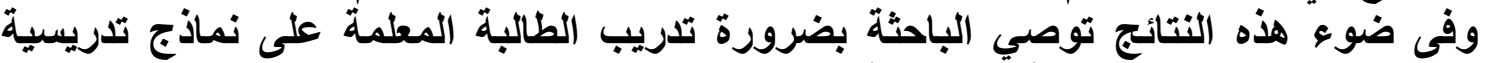

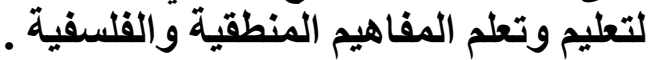

\section{Research Summary :}

This research aims at revealing the effectiveness of a proposed program that based on frier model for development of basic logical concepts, self-efficacy and the survival of the impact of learning among female students teachers .

From Division philosophy:

To achieve this aim , the researcher prepared the following :

1- Experimental tools: they are introduced in the proposed program in the light of frier model.

2- Measurement tools: They in clude a test in the basic logical concepts, self-efficacy scale . the study sample consisted of (30) students , third year, Division philosophy and the researcher applied the measurement tools an the sample then taught the proposed program : After that the researcher applied the remote measurement application and it was shown from the results the effectiveness the proposed program in developing the logical concepts, self-efficacy and the existence of the impact of learning for the student teacher .

In the light of those results, the researcher recommends the necessity of training the student teacher on teaching models .

The previous researcher proved their effectiveness in teaching and learning concepts of logic philosophy. 
يحتل المعلم في النظام التربوي مكان الصدارة في إنجاح هذا النظام وتحقيق أهدافهه، وبالرغم

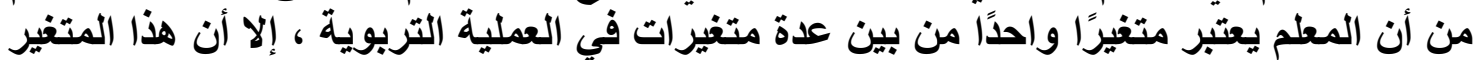

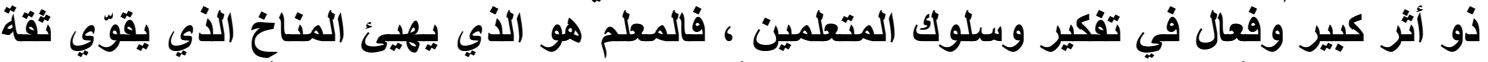

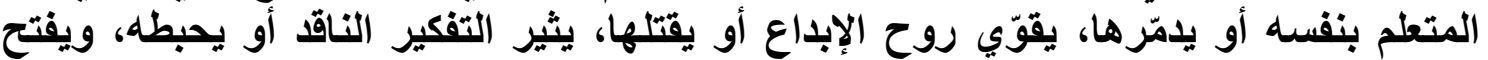

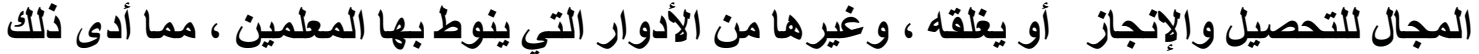

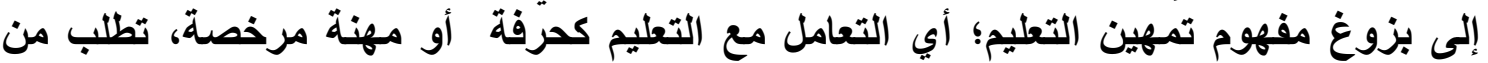

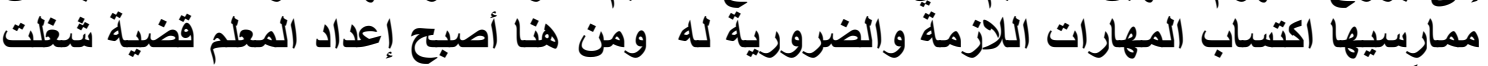

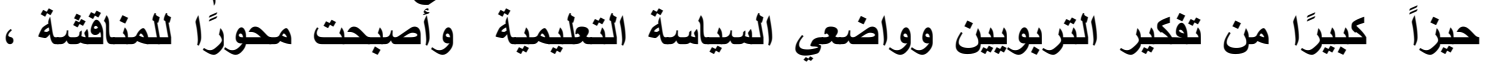

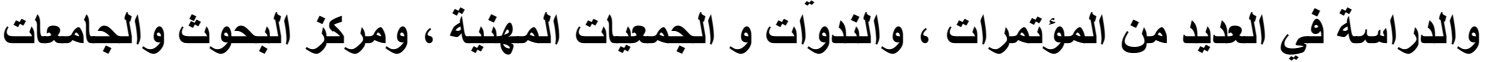

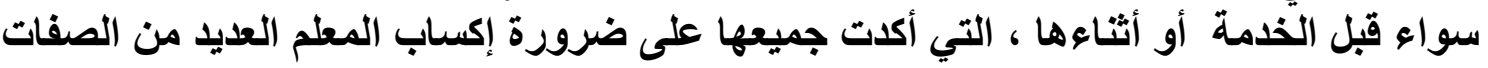
منها :

1)-الاعتماد في القيام بالمهام المطلوبة منه على قاعدة معرفية متينة . Y (إدراك أهمية تطوير نفسه و إمكاناته وقدر اته .

ب)-الاهتمام بضرورة استخدام استراتيجيات مختلفة في حجرة الدراسة . ع)-تكوين اتجاهات إيجابية لايه نحو مهنة التدريس • •)-أن يكون متزنًا (نفعاليًا ‘) أن يمتلك مهارات الاتصال والحوار الإيجابي . ( أن يكون واسع الاطلاع، ولايه ثقافة متنوعة .

أي يجب عند إعداد الطالب المعلم أن يرتبط بما ينبغي عليه عمله بعد تخرجه، وما تتطلبه مهنته

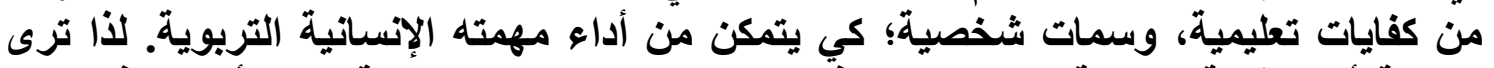

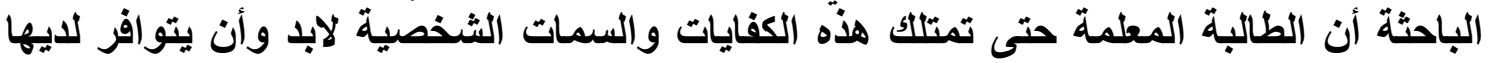
جانبين أساسيين هما:

1 ـالتمكن من محتوى مادتها ، وذللك بالإطلاع المستمر على كل جديد في مجال التخصص .

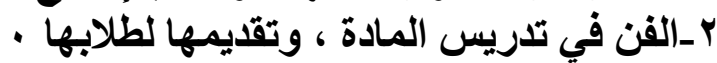

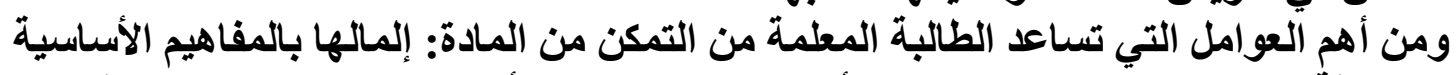

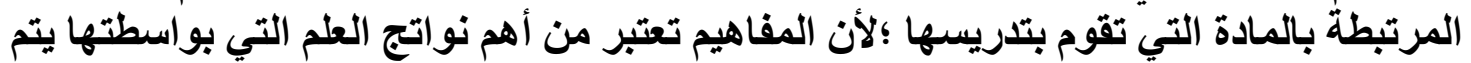

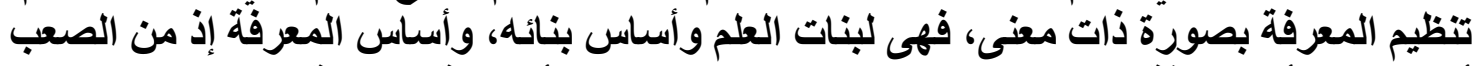

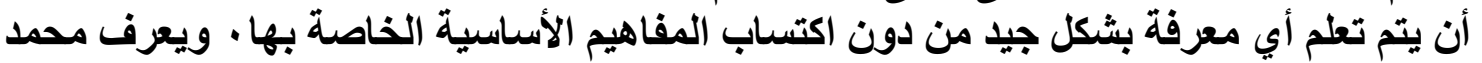

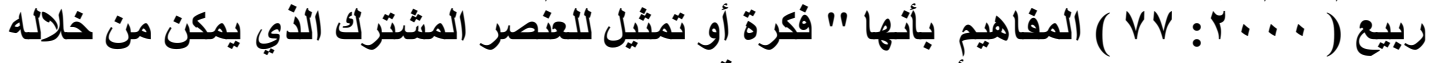

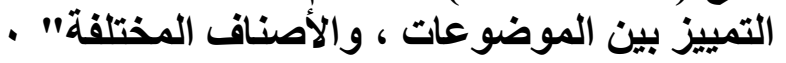




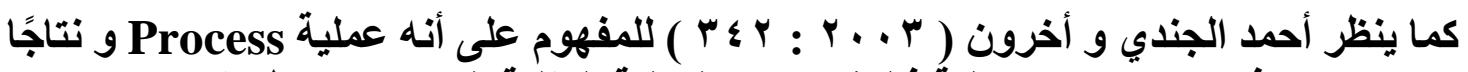

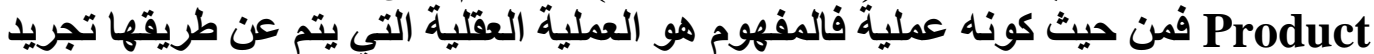

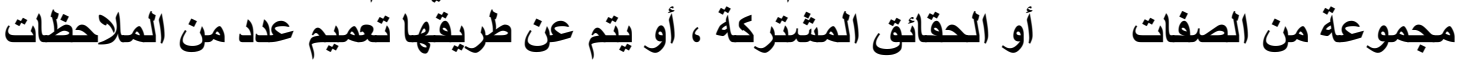

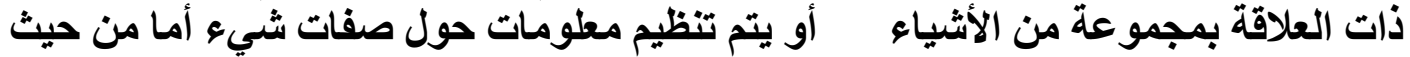

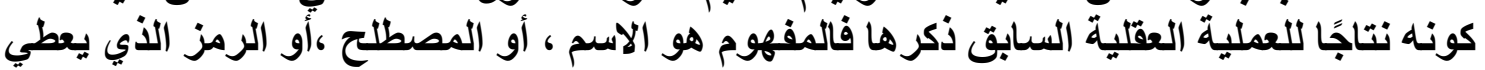

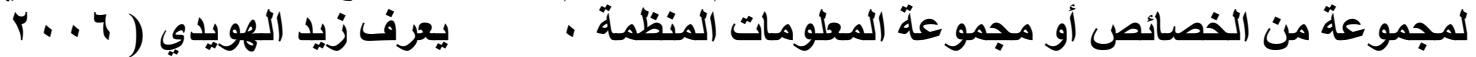

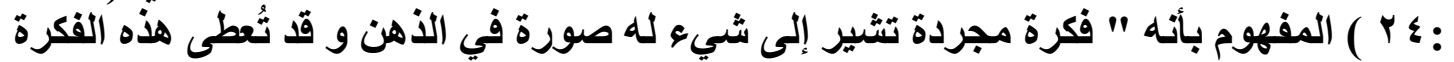

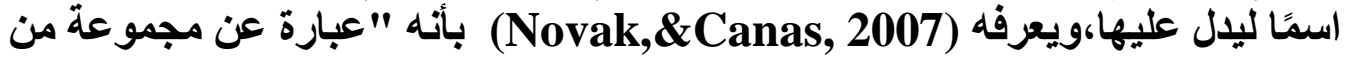

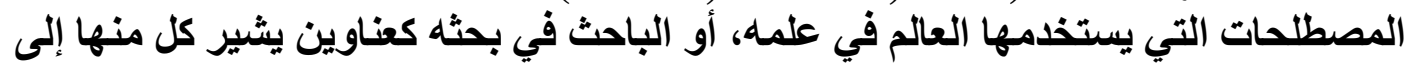

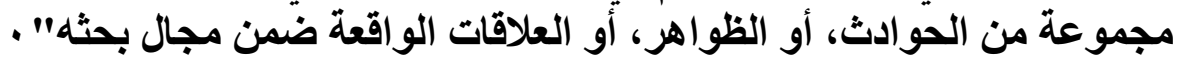

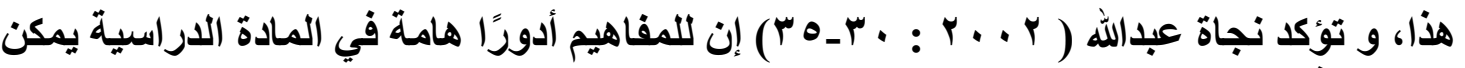

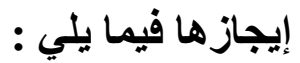

1- تنظيم المحتوى : حيث تثكل المفاهيم إحدى الدعائم التي يستند عليها عند إختيار محتوى

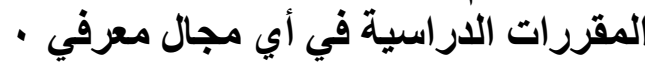

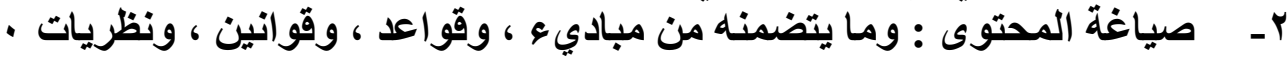

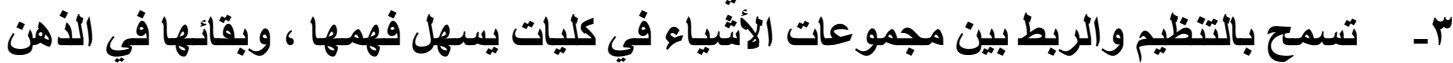
أكثر من الجزئيات المنفصلة. ـ -يقلل من الحاجة إلى إعادة التعلم عند مواجهة مواقف جديدة .

هـمساعدة المتطلم على الارتقاء بقدراته العقلية ، ومساعدته لتحفيز قدراته العقلية العليا في

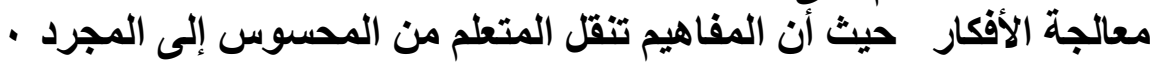

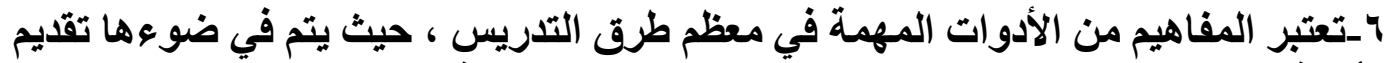

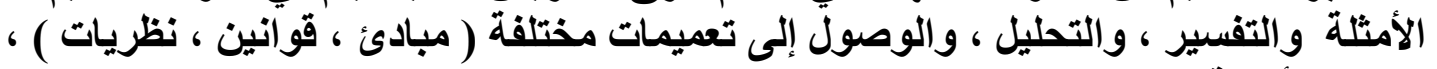
وطرح الأسئلة وتصنيف وتنظيم المعلومات .

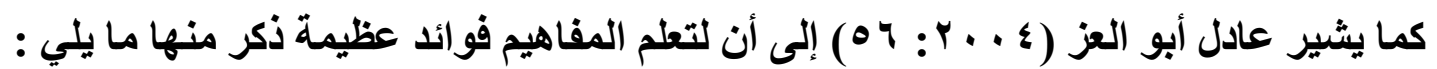
* تقلل من تعقد البيئة إذ أنها تلخص ، وتصنف ما هو موجود في البيئة من أشياء أو مواقف. * تعد الوسائل التي تعرف بها أشياء موجودة في البيئة. * تقلل الحاجة إلى إعادة التعلم عند مواجهة أي جديد ـ * تساعد على التوجيه ، و التتبؤ ، والتخطيط لأي نشاط. * تسمح بالتنظيم والربط بين مجموعات الأشياء والأحداث.

و هكذا تعد المفاهيم من الركائز الأساسية في العملية التعليمية، وذلكل لما لها من دور في تنظيم

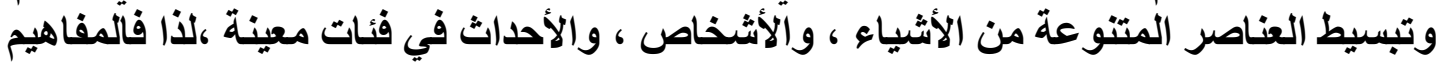

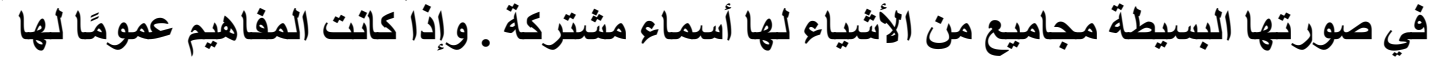


أهمية _ كما يتضح مما سبث - فالمفاهيم المنطقية لها أهمية خاصة لما لهذه المادة المادة من طبيعة

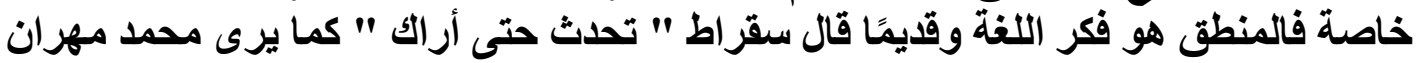

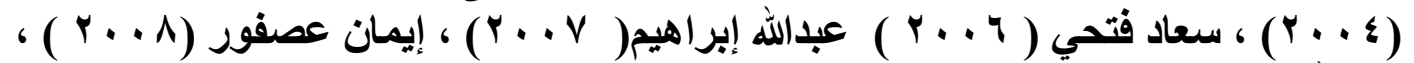

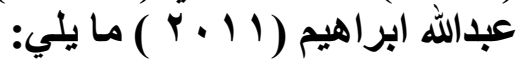

1 - يعتبر علم المنطق من أهم العلوم على الإطلاق، لأنه مقدمة العلوم، وبه يتدرب طالب العلم

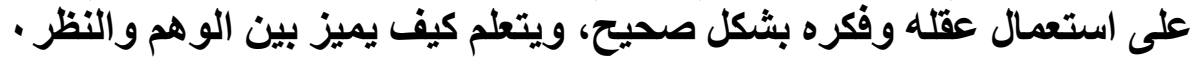

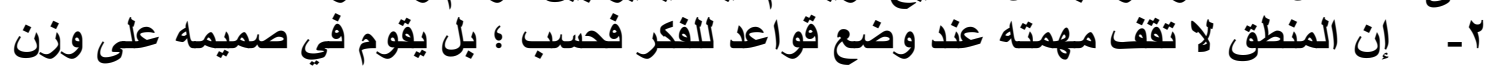

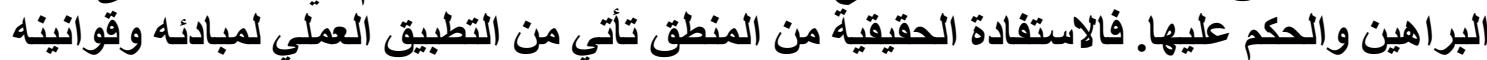

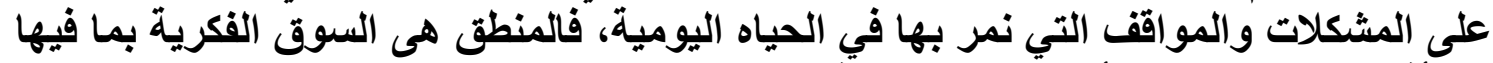

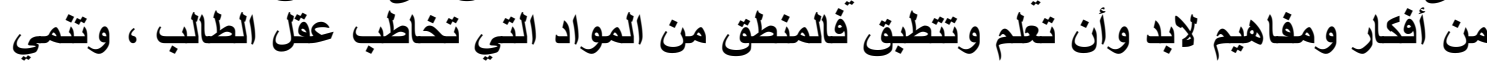

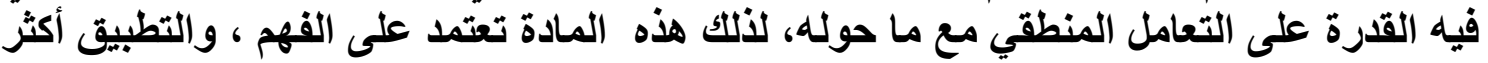
من الحفظ والتذكر.

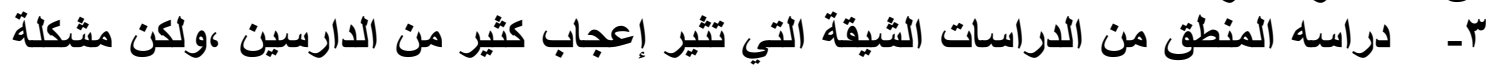

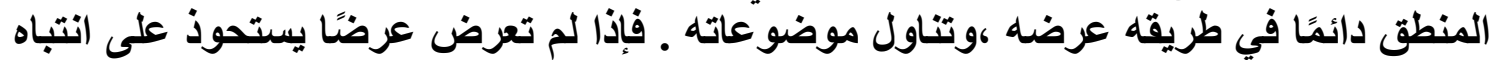

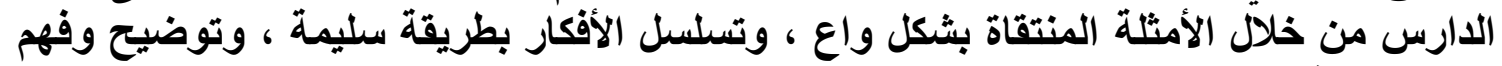

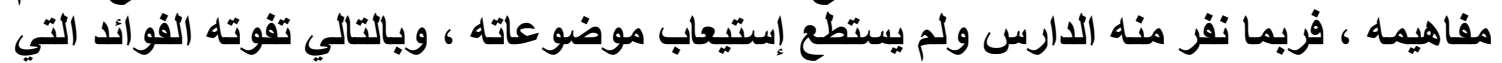

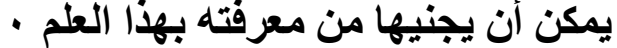

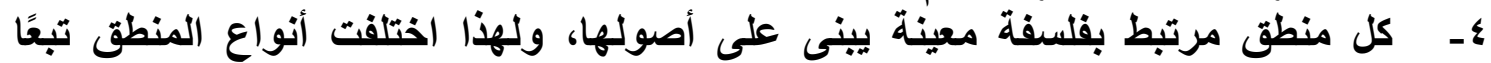

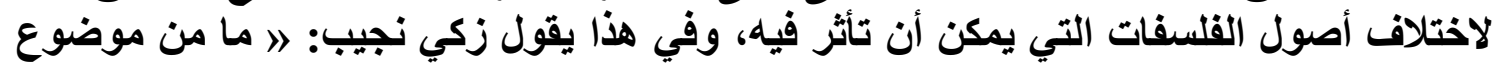

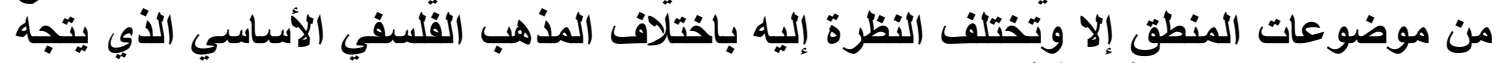

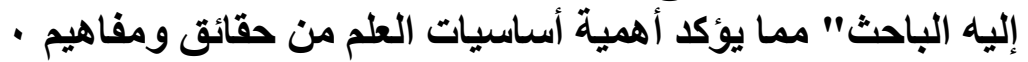

ولقد ظهرت بعض النماذج التدريسية التي لاتقتصر على مجرد إكساب المفهوم ولكن يهتم أيضا

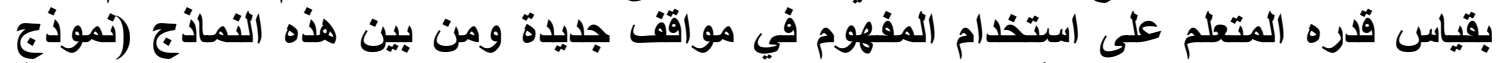

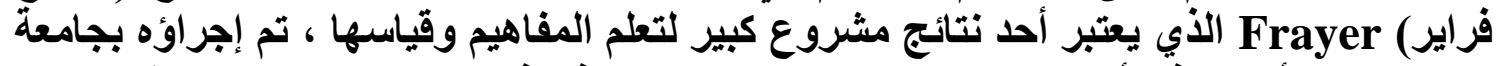

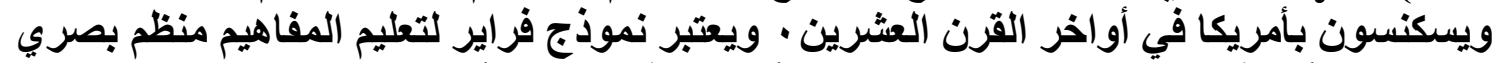

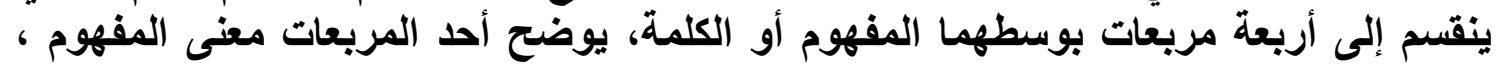

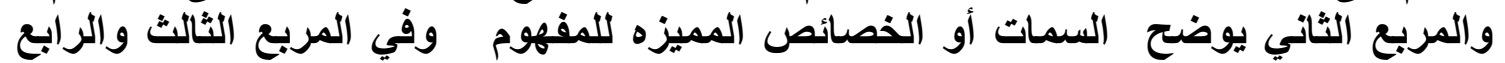

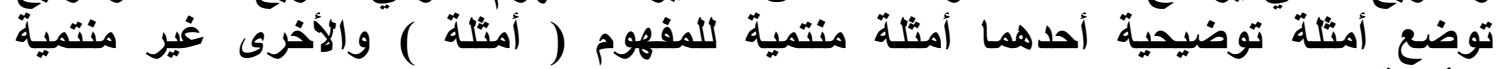

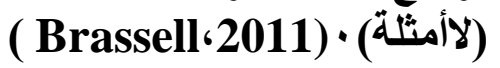

هذا ، ومما لا شك فيه أن السلوك التعليمي للطالبة المعلمة لا يتأثر بمعرفتها العلمية والثقافية

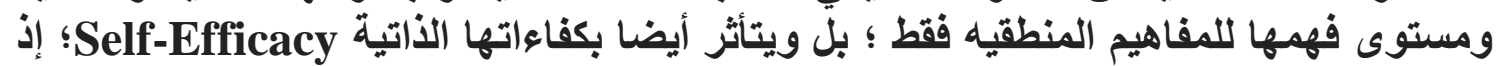

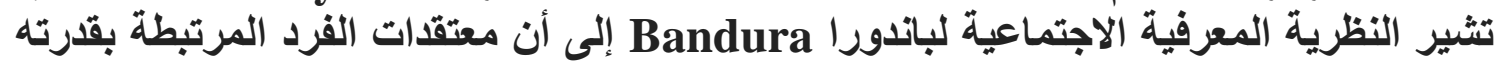

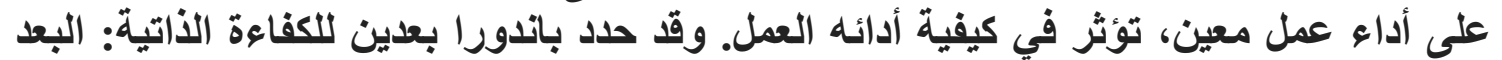

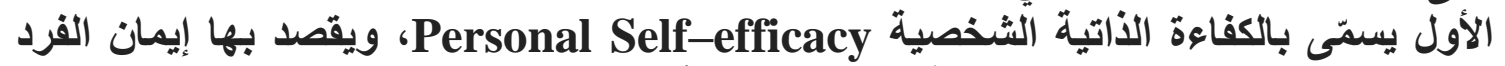

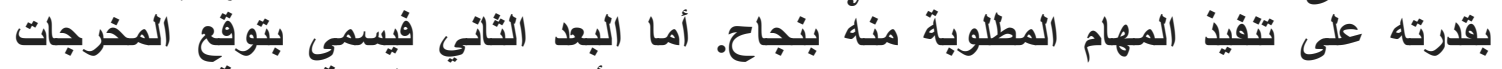
Outcome Expectancy النتائج المطلوبة. 
لألك إلى جاتب اهتمام البحث الحالي بالمفاهيم المنطقية لاى الطالبات المعلمات شعبة فلسفة

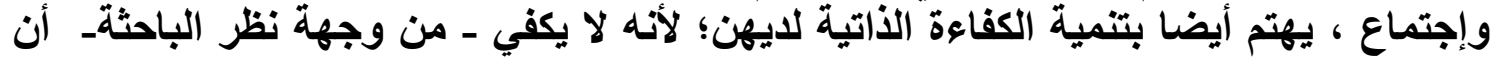

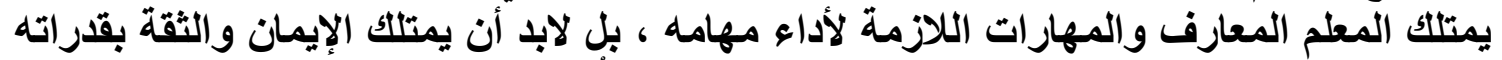

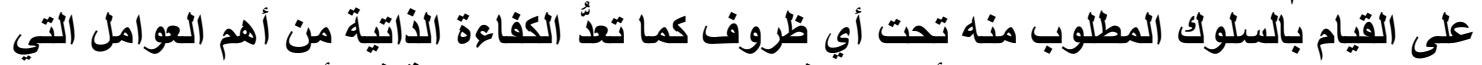

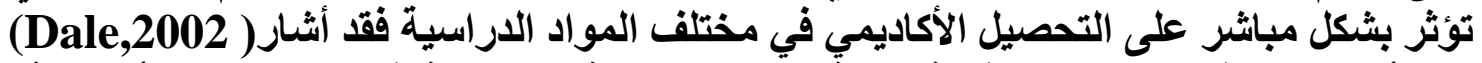

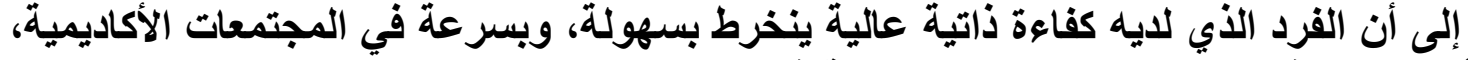

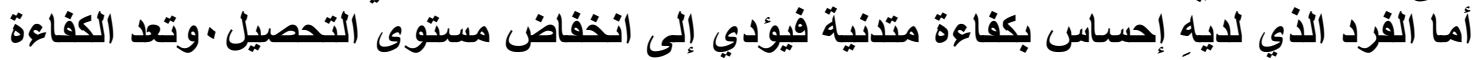

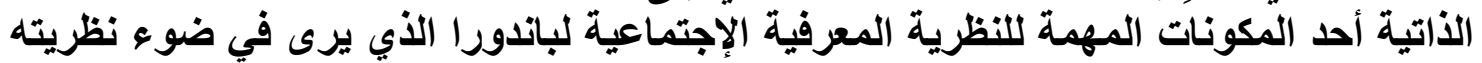

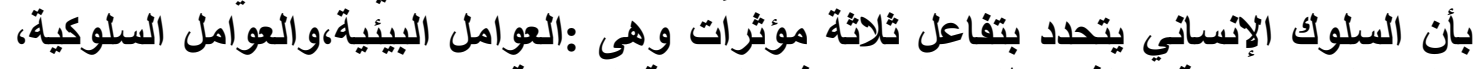

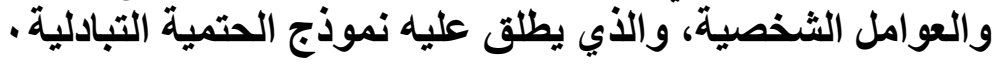

يعرف باندورا (. Bandura,1997: 71 ) الكفاءة الأتية بأنها" مُعتقدات الفرد حول قدرته على تنظيم، وتنفيذ الإجراءات اللازمة لتحقيق نتائج مُعينة .

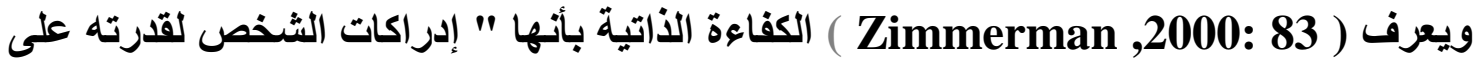

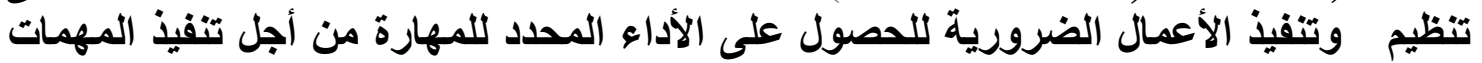

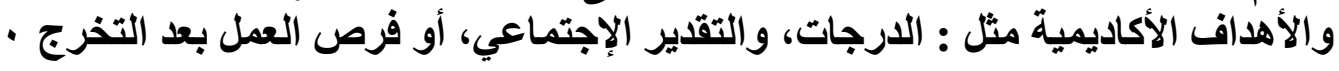

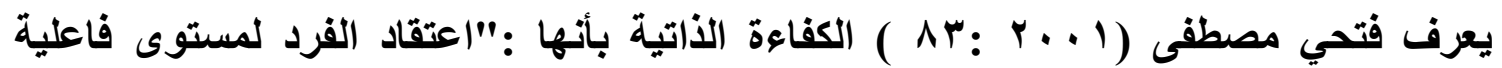

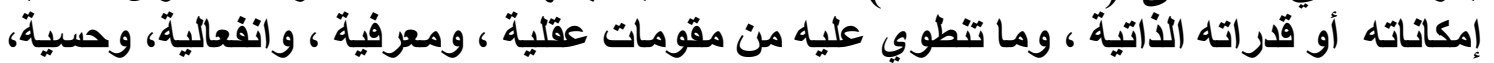

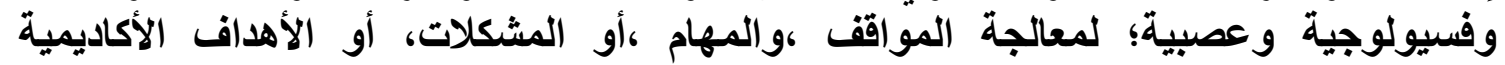

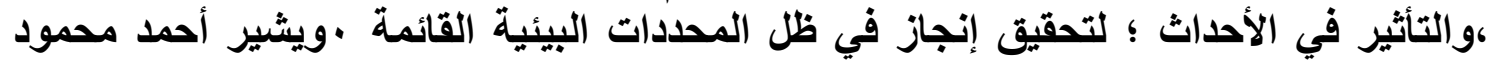

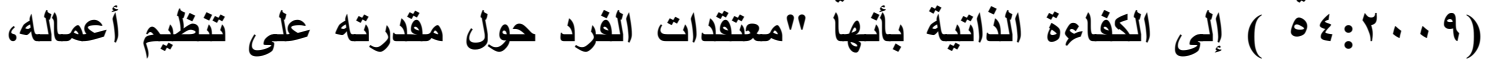

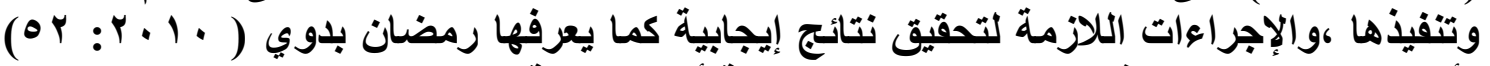

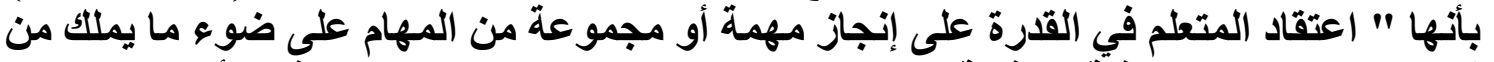

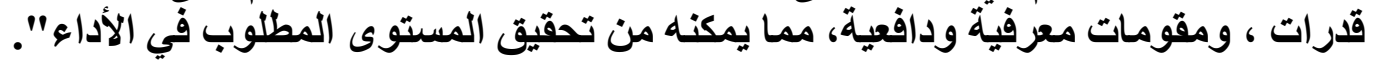

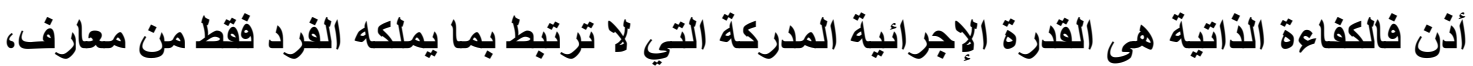

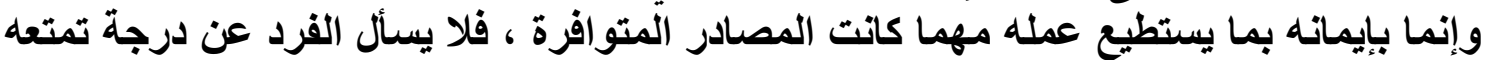

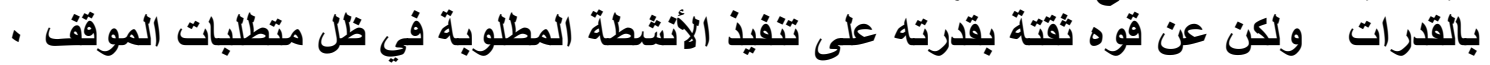

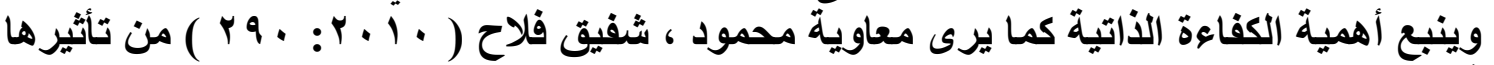

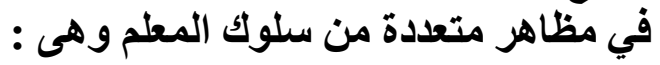

ا ـاختيار النشاطات : فالأفراد ذو الإحساس المرتفع بالكفاءة الأاتية يميلون إلى اختيار الأنثطة

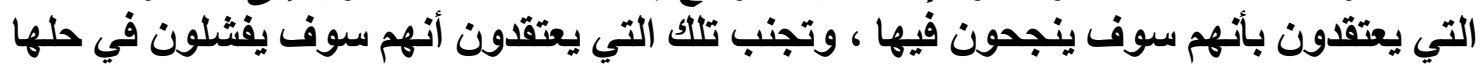

ץ.التعلم والإنجاز : فالأفراد ذو الإحساس المرتفع بالكفاءة الذاتية يميلون إلي التعلم و الإنجاز

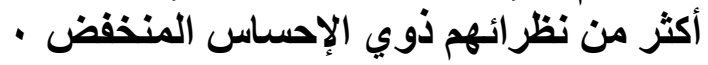

r-الجهد المبذول والإصرار : فالأفراد ذو الإحساس المرتفع بالكفاءة الأتية يميلون إلي بذأل

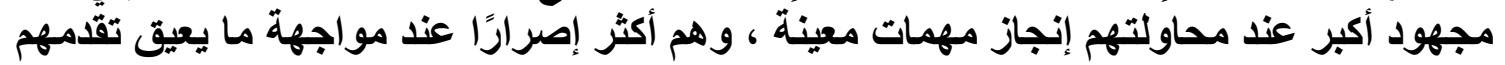


ونجاحهم ، أما الأفراد ذو الإحساس المنخفض بالكفاءة الذاتية فيبذلون جهدًا أقل في أداء المهام ،

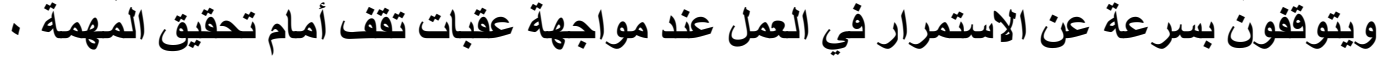

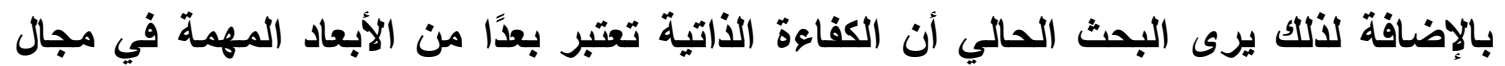

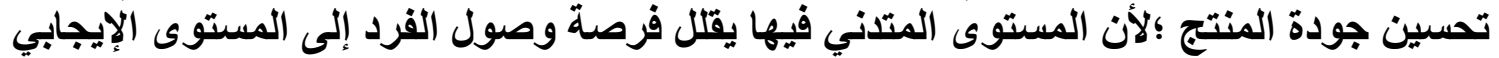

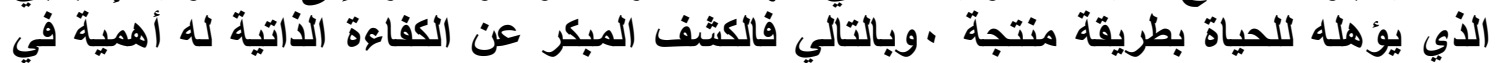

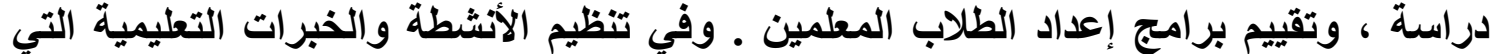

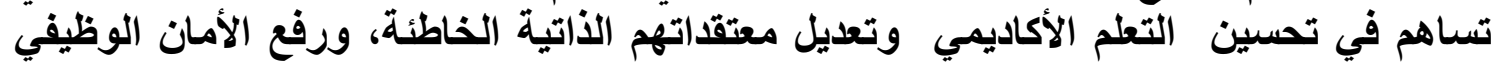

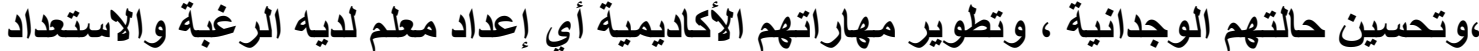
و والقدرة للعملية التدريسية الوجية ، والئ

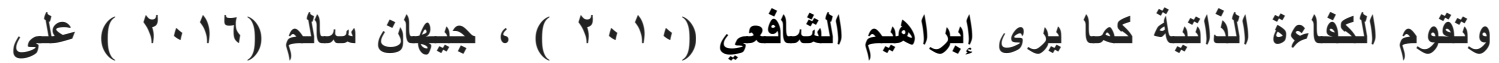
مجموعة من الافتراضات تثمثل في الآتي :-

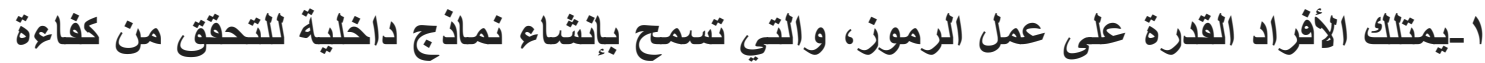

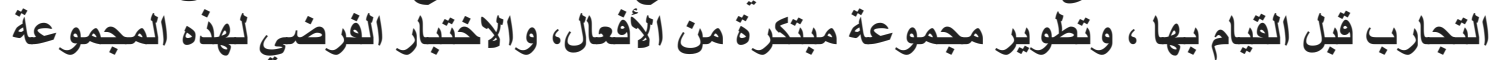

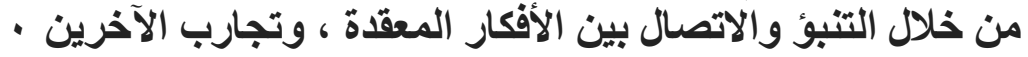

ب-يمتلك الأفراد القدرة على التنظيم الأتي ، عن طريق التأثير على التحكم المباثر في سلوكهم ،

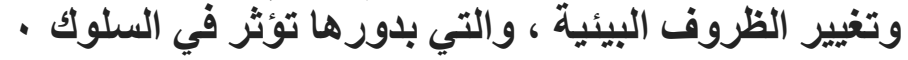

r-يمتلك الأفراد القدرة على التأمل الذاتي ، وتحليل وتقييم الأفكار والخبرات الذاتية حيث أن هذه القدرات تتيح عملية التحكم الأتي في كل من الأفكار والسلوكل .

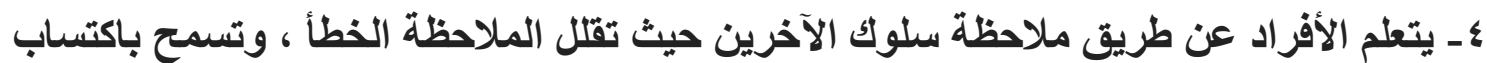

المهارات المعقدة بثكل أسرع ، والتي ليس من الممكن اكتسابها فقط عن طريق الماحل الممارسة .

هـتثفاعل كل من الأحداث البيئية ، و العوامل الذاتية الداخلية ، و السلوك بطريقة متبادلة .

الثعور بالمشكلة وتحديدها :

نبع الثعور بالمشكلة من خلال عدة محاور :

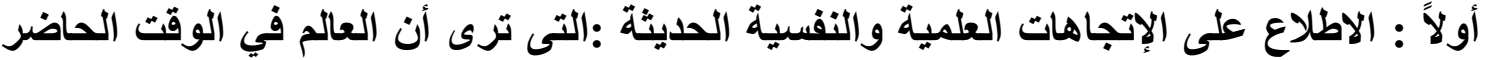

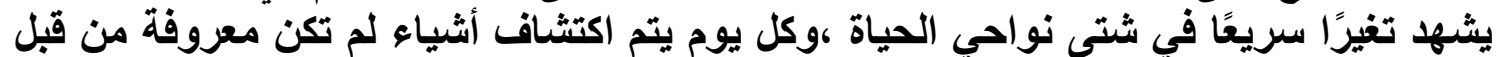

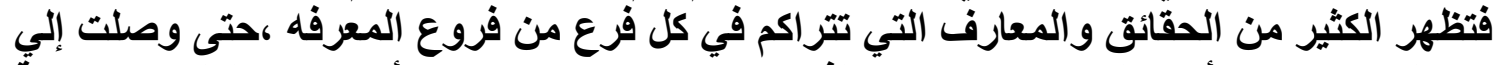

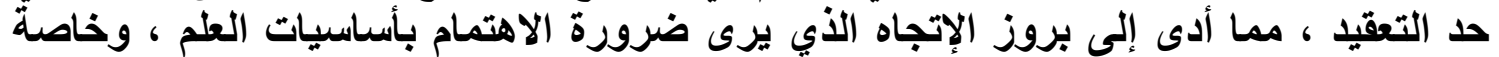

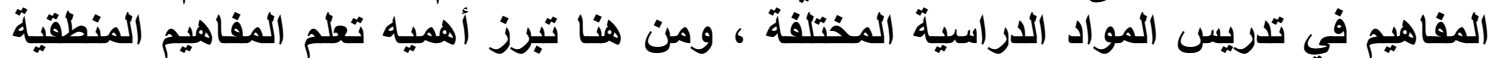

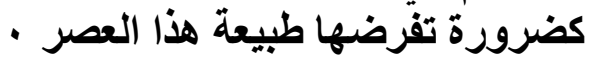

ولكن لا يكفي - من وجهة نظر الباحثة أن يمتلك المعلم المعارف والمهارات اللازمة لألداء

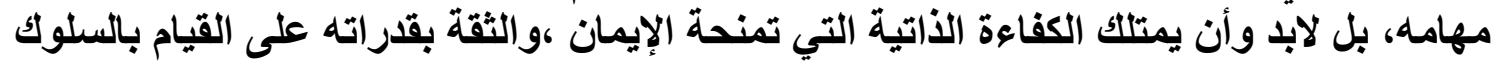


المطلوب منه تحت أي ظروف ، ورفع الإمان لايه .ولكن الباحثه لاحظت من خلافل القيام بتدريس

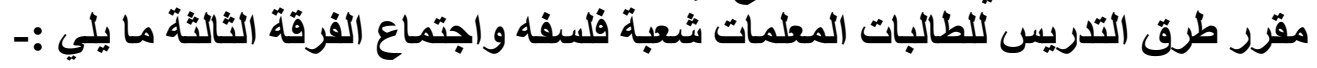

ا- - تعثر الكثير منهن عن تحضير درس في المنطق ،وبمناقشة بعض الطالبات اتضح أن

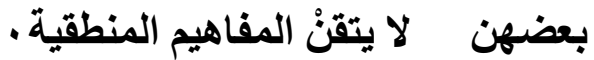

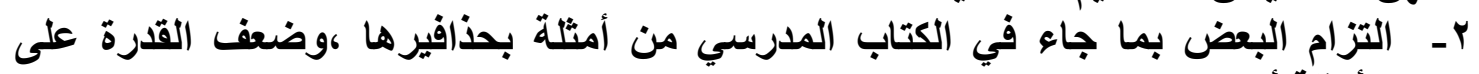

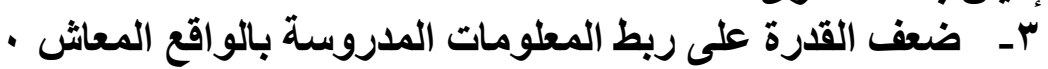

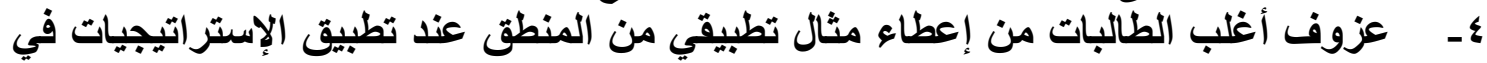

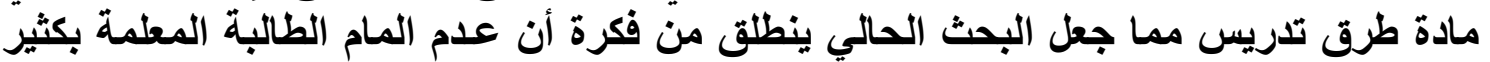

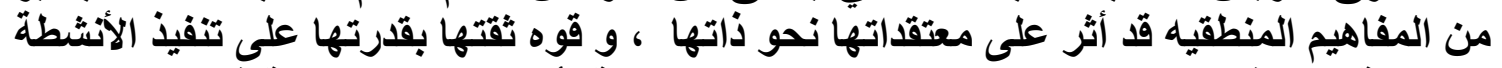

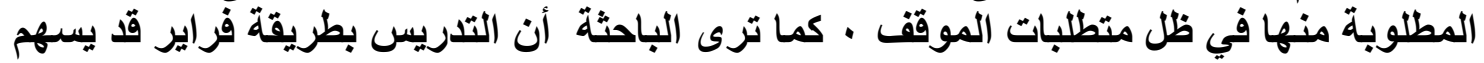

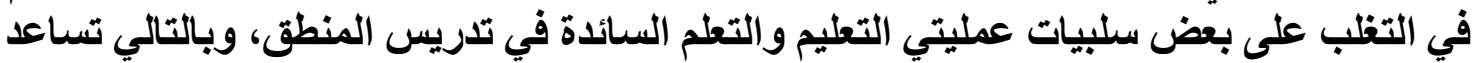

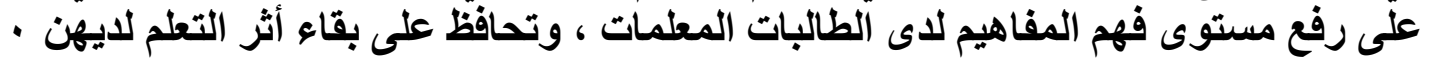

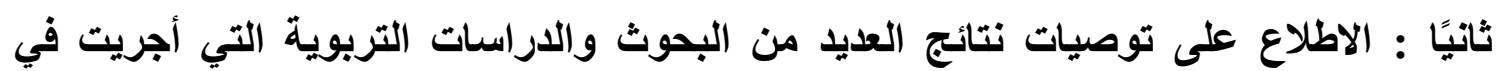

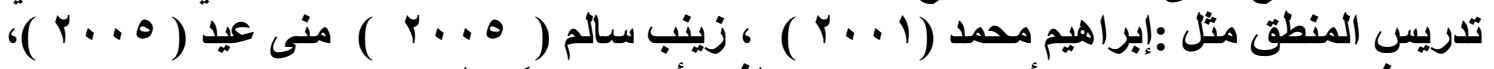

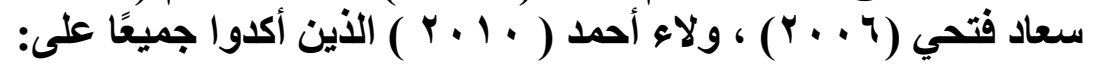

ا ضرورة الاهتمام عند تدريس المنطق أن يتفهم الطالب المعلم تفهمًا كاملاً أساسيات ومفاهيم

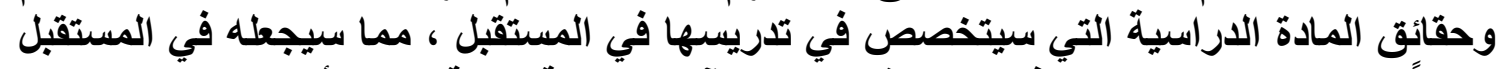

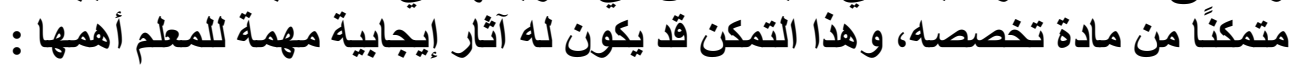

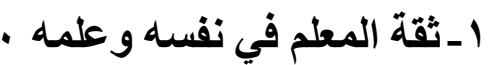

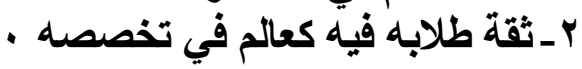

ب-يسهل عليه ربط مادته الاراسية بتطبيقات علمية وحياته مما يضفي على مادته قيمة ،تربوية، وحياته

وعلى الرغم من كثرة الاراسات التي أعدت في مجال تدريس المفاهيم إلا إن الإطلاع علي

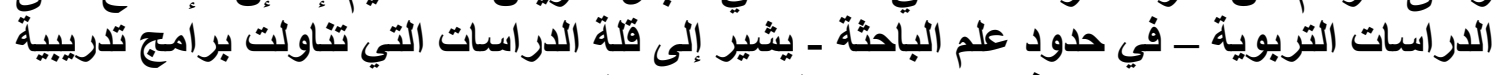

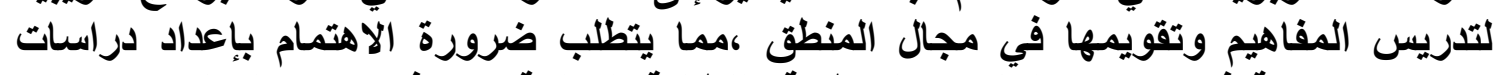

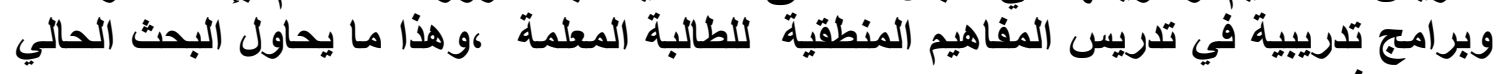
الإسهام فيها .

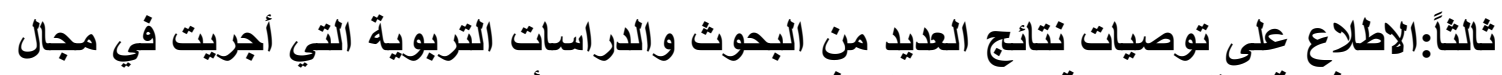

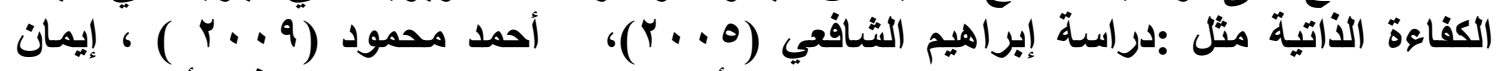

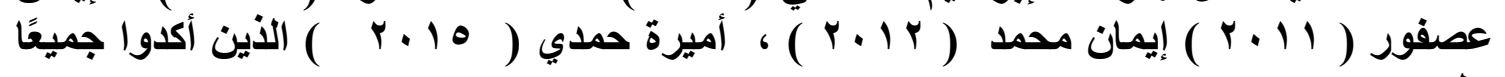
على:

أـ رورةة بناء وتصميم وتطبيق برامج تدريبية للطالب المعلم لتنمية كفاعاته الذاتية قبل مزاولته لمهنة التدريس لـاء وتصن 


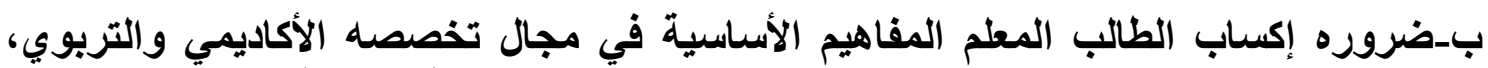

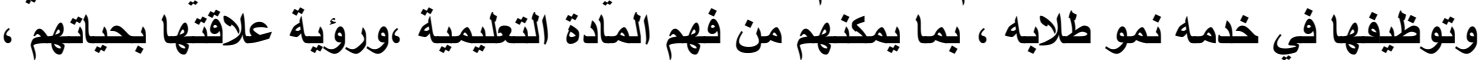

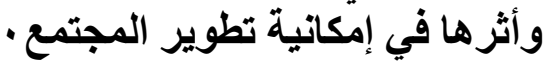

ج-ضروره إكساب الطالب المعلم مهارات التعلم الذاتي ؛ ليتمكن من متابعه كل جديد في مجال

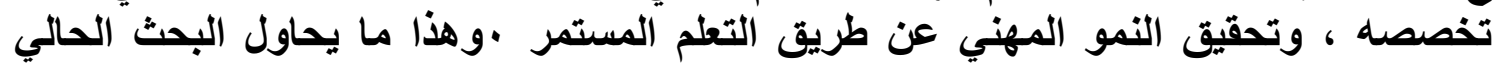

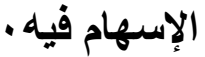

ولتدعيم الإحساس بالمشكلة قامت الباحثة بالإجراءات التالية :

إجراء دراسة استطلاعية على طالبات الفرقة الثالثة بكلية البنات البالغ عددهن ( ه ب ) طالبة

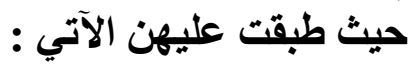

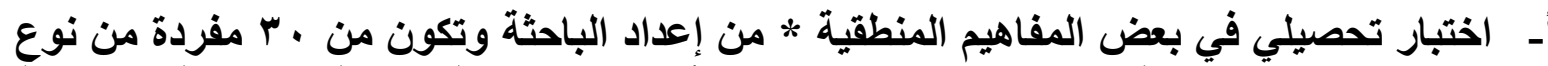

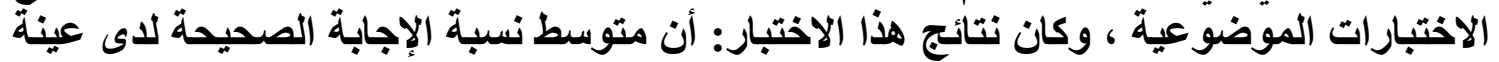

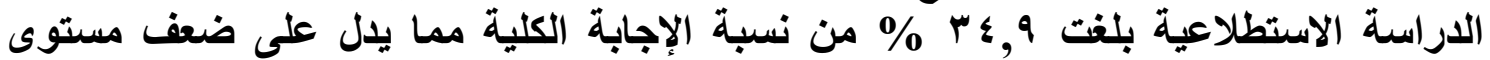

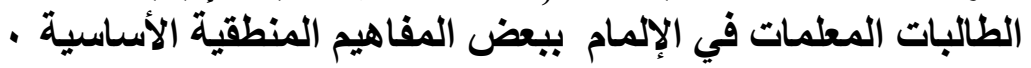

ملحق(البات المطي:

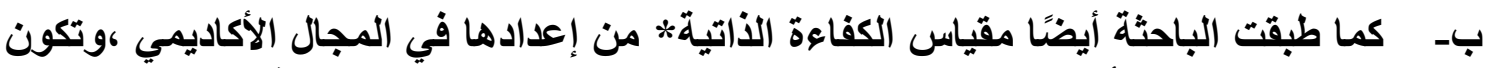

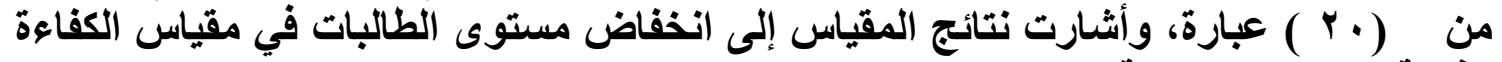

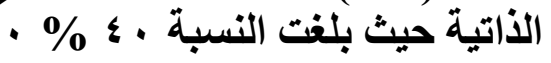
وفي ضوء مما سبق تتخلص مشكلة البحث الحالي في : أن الطالبة المعلمة شعبة فلسفة واجتماع تعاني من ضعف في إمتلاكها للمفاهيم المنطقية وكذلك

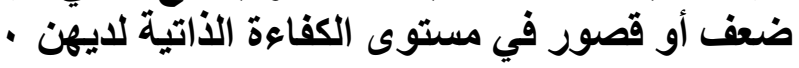
وفي ضوء ذلكك يمكن صياغة مشكلة البحث الحالي في التساؤل الرئيسي التالي :

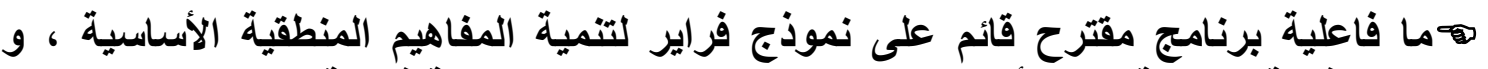

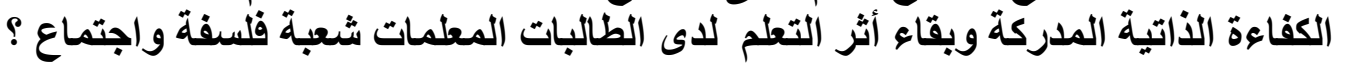
و يتفرع عن هذا السؤال الرئيسي الأسئلة الفرعية الآتية :

1 ـ ما المفاهيم المنطقية الأساسية اللازمة للطالبات المعلمات شعبة فلسفة واجتماع ؟

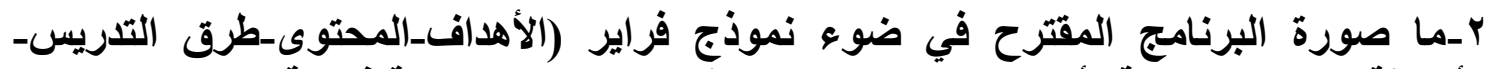

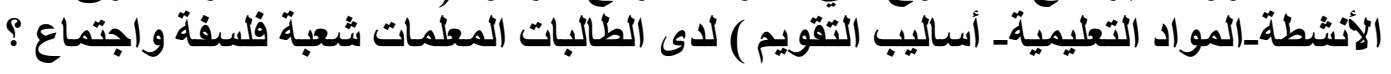
ץ- مـا فاعلية البرنامج المقترح في تنمية المفاهيم المنطقية الأساسية لاى الطالبات المعلمات شعبة فلسفة واجتماعُ البرناعج 
ع ـما فاعلية البرنامج المقترح في تنمية الكفاءة الذاتية المدركة لدى الطالبات المعلمات شعبة

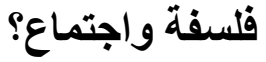

هـما فاعلية البرنامج المقترح في بقاء أثر التعلم لاى الطالبات المعلمات شعبة فلسفة واجتماع؟

أهد|ف البحث: :

$$
\text { يسعى البحث الحالي إلى تحقيق الأهداف الآتية : }
$$

ـاكثف عن مدى فاعلية البرنامج المقترح القائم على نموذج فراير في تنمية الأتي :

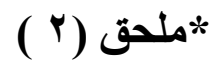

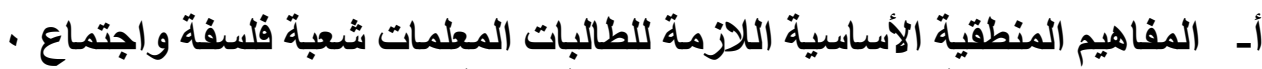

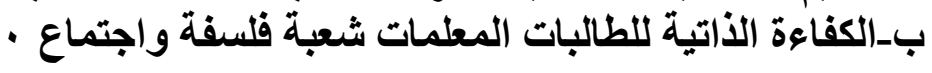

ج- مدى بقاء أثر التعلم للمفاهيم المنطقية لاى الطالبات المعلمات شعبة فلسفة واجتماع.

$$
\text { أهمية البحث : ماءث: }
$$

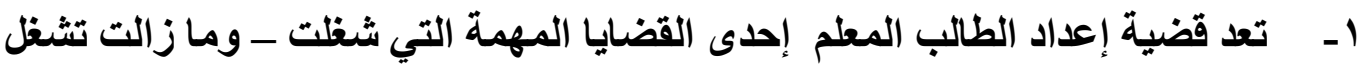

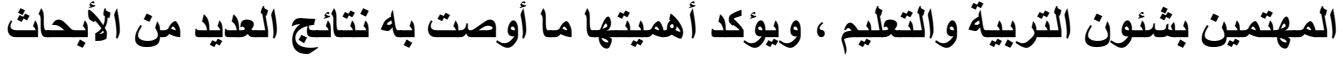

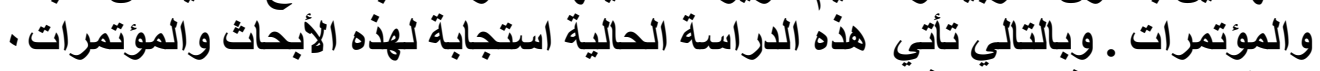

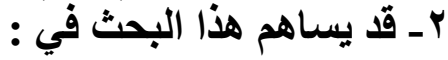

بالنسبة لمخططي ومطوري برامج إعداد المعلم أـ قد تثكل نتائج الدراسة الحالية إفادة للقائمين

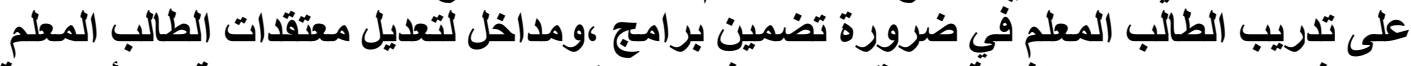

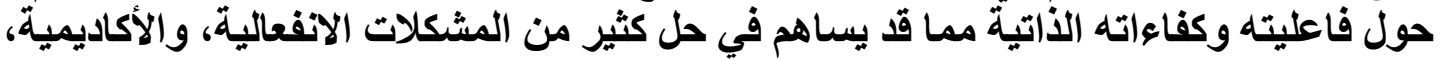

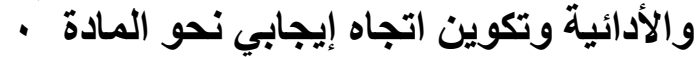

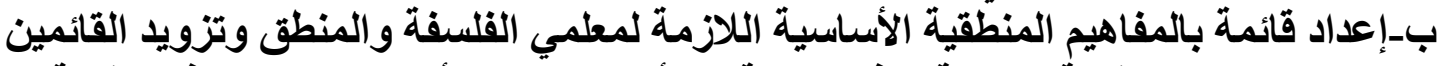

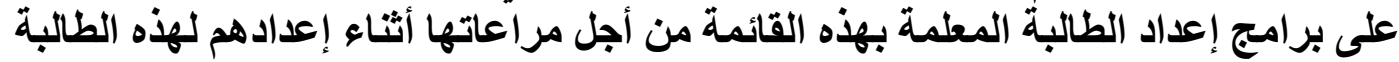

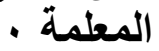

بالنسبة للطالبات المعلمات أـ تزويدهن بقائمة من المفاهيم المنطقية الأساسية التي سوف

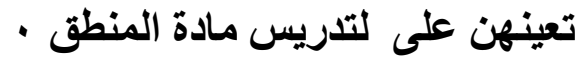

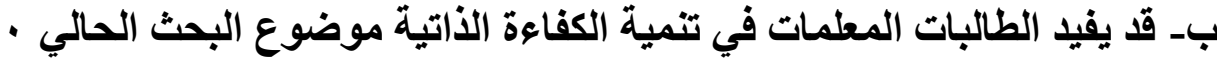

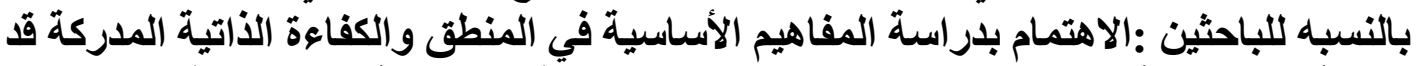

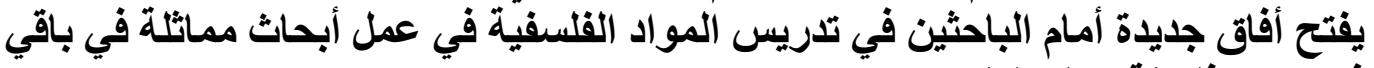

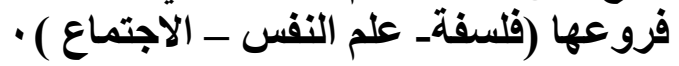
حدود البحث: اقتصر البحث الحالي على : اق 


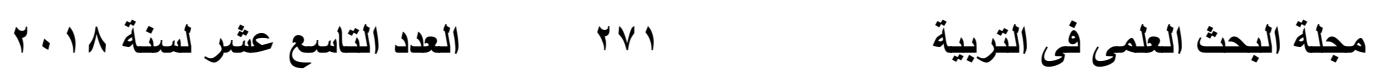

1- الحد البشري : الطالبات المعلمات شعبة فلسفة واجتماع الفرقة الثالثة .

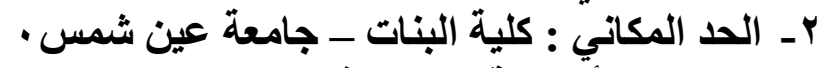

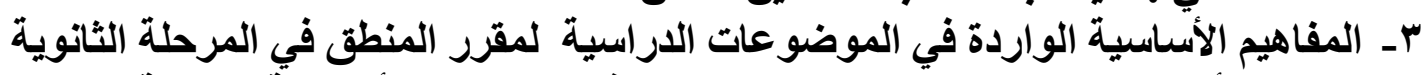

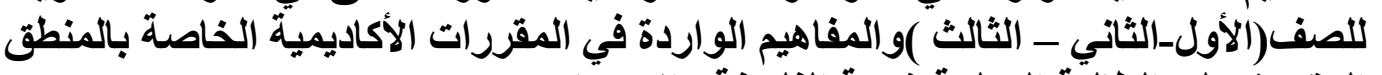

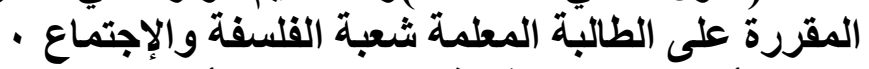

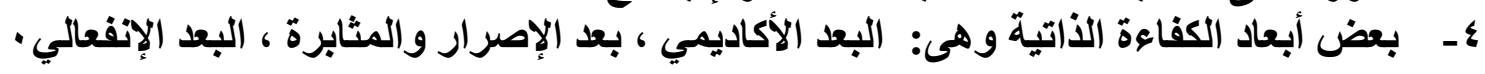

$$
\begin{aligned}
& \text { أدوات البحث: } \\
& \text { تثمثل أدوات البحث الحالي في : } \\
& \text { أ-مواد التجريب ،وتتمثل في الآتي : }
\end{aligned}
$$

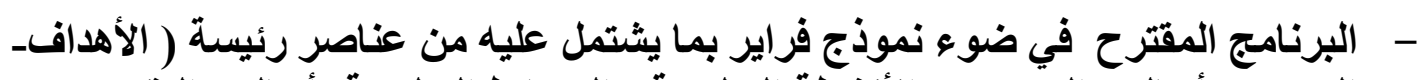

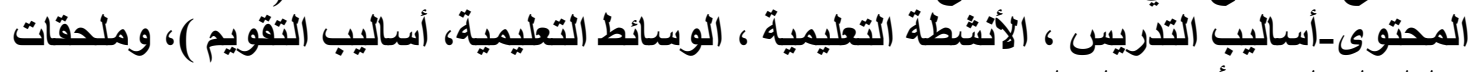
(دليل المعلم ، وأوارق العمل الثرين

$$
\text { ب-أدوات القياس ،وتتمثل في الآتي : }
$$

1 - إعداد اختبار في المفاهيم المنطقية الأساسية المتضمنة في البرنامج المقترح .

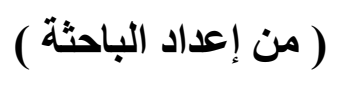

ץ ـ مقياس للكفاءة الذاتية وأبعاده :( البعد الأكاديمي ، بعد الإصرار والمثابرة ، البعد الانفعالي) ( من إعداد الباحثة ) ( من )

\section{فروض البحث:}

ا - يوجد فرق دال إحصائيًا بين متوسطى درجات الطالبات المعلمات في إختبار المفاهيم المنطقية

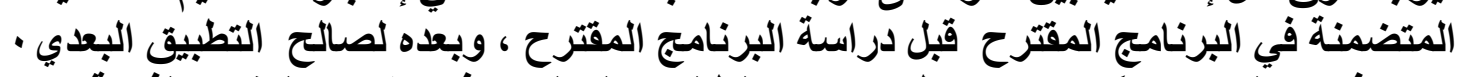

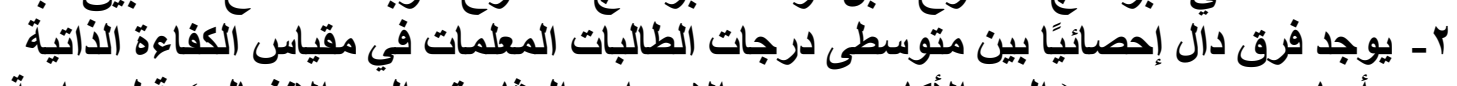
وأبعاده

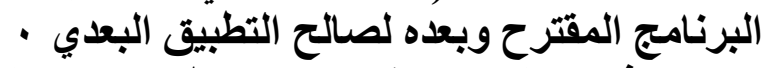
بـ لا يوجد فرق دال إحصائيًا بين متوسطى درجئ درجات الطالبات المعلمات في التطبيقين البعدي و البعدي

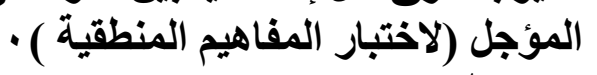
منهج البحث (لاثن

تم الاعتماد في هذا البحث على منهجين هما :

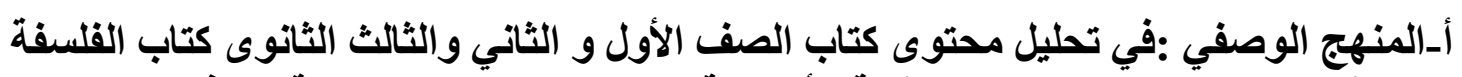

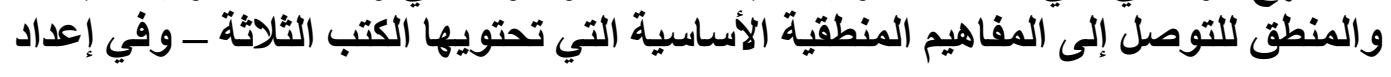


البرنامج وأدوات البحث والإطار النظري وتحليل ومناقشة وتفسير النتائج - وعرض التوصيات

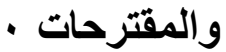

بـالمنهج التجريبي : وذلك فيما يتعلق بتجربة البحث، وضبط متغيراته ،وسوف يتم الاستعانة

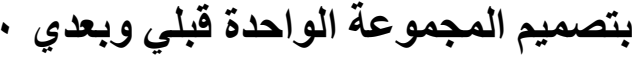

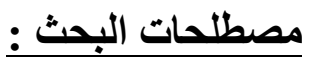

يثكل تحديد المصطلحات أهمية كبيرة في الاراسات التربوية عامة و الاراسات الإنسانية بصفة

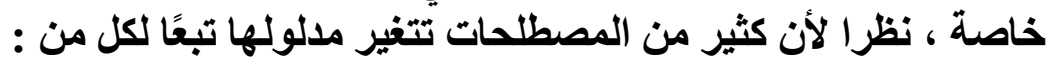

ب) الإطار النظري الذي تنطلق منه الاراسة .

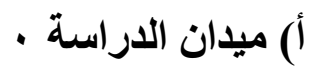

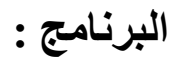

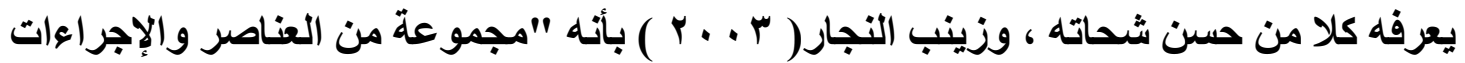

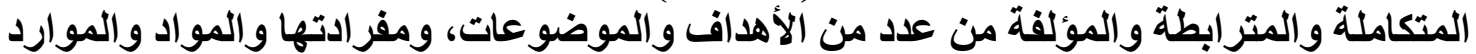

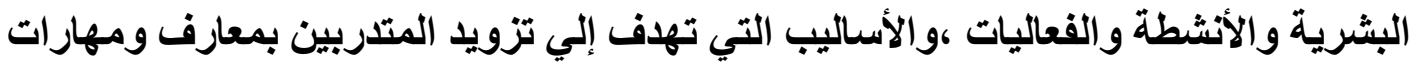

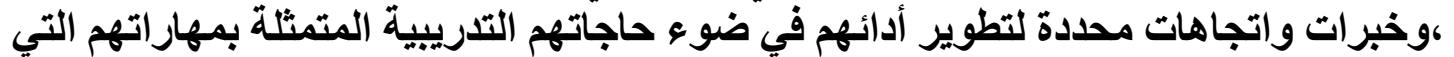
ظهز ضعف في أدائها " .

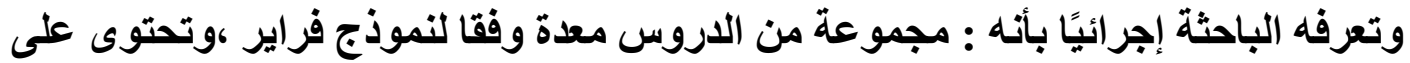

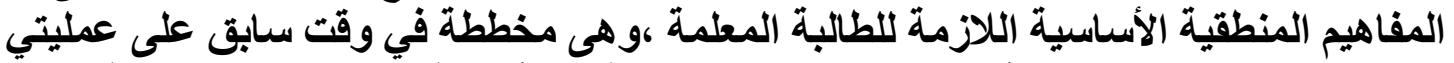

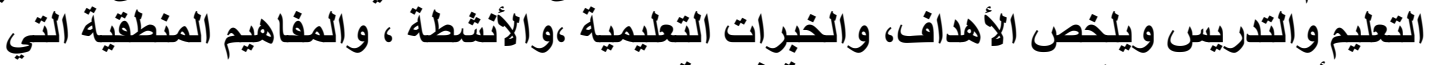

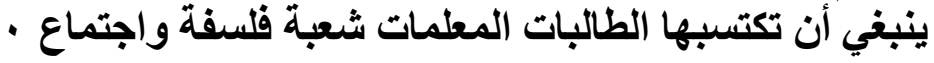
نموذج فراير:

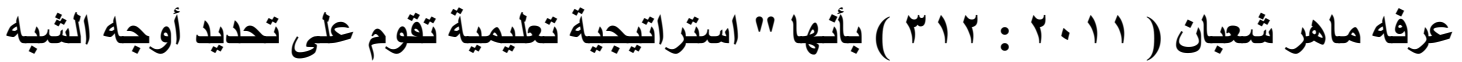

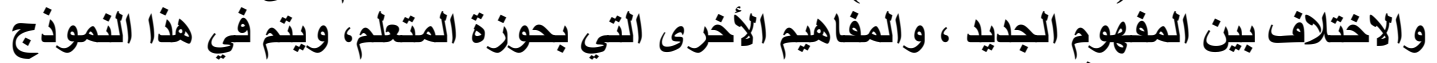

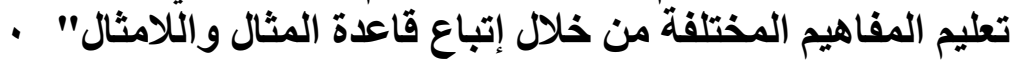

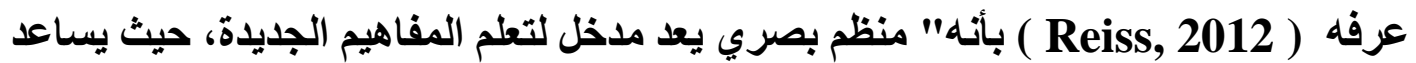

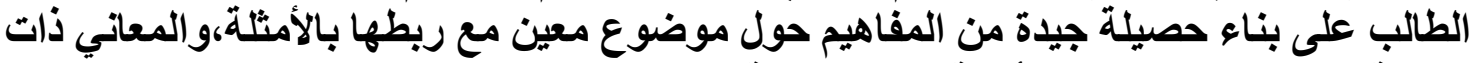

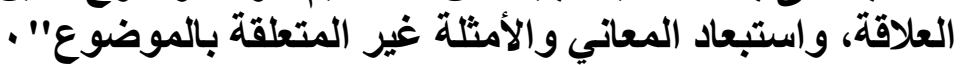

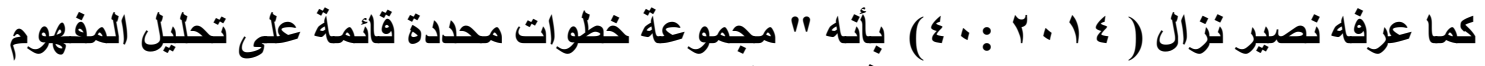

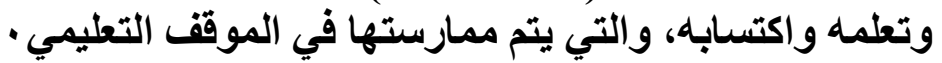

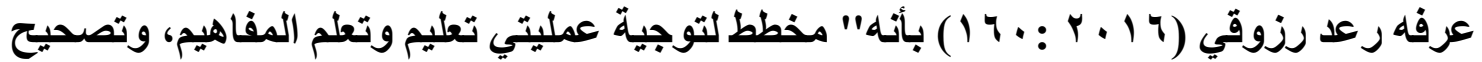

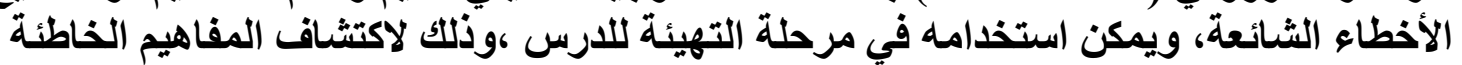
لاى الطالب." 


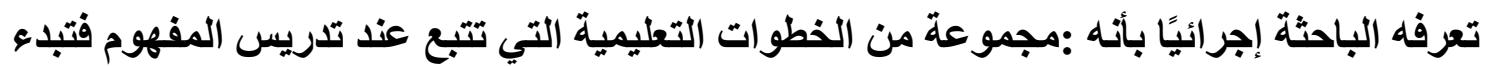

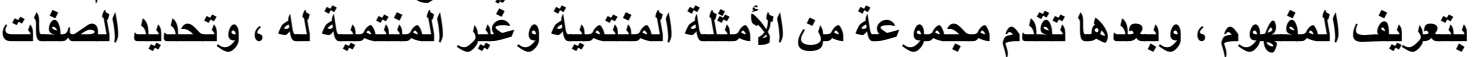

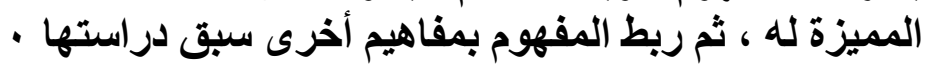

\section{المفاهيم المنطقية :}

قام العديا من التربويين وعلماء النفس التربوي بوضع تعريفات متنوعة للمفهوم منها :

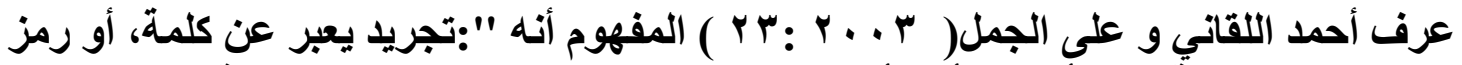

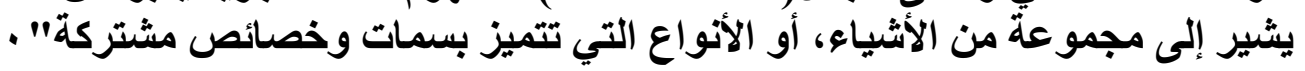

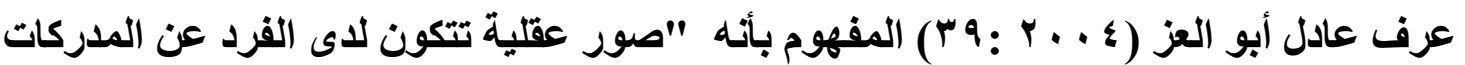

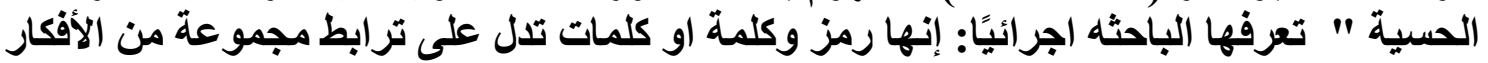

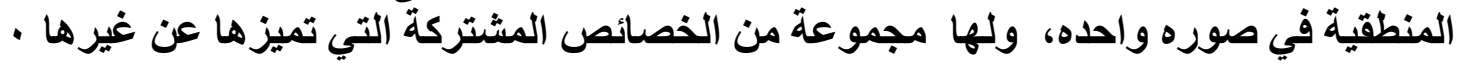

\section{الكفاعة الذاتية :}

قام العديد من التربويين وعلماء التفس التربوي بوضع تعريفات متتوعه للكفاعة الأتية المدركة

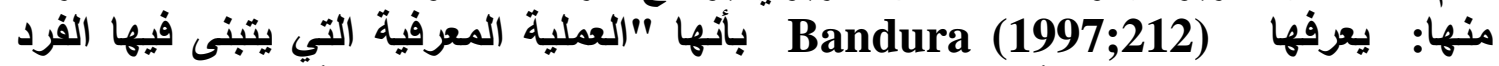

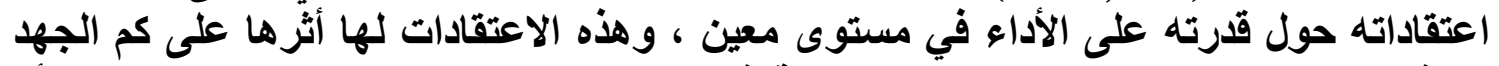

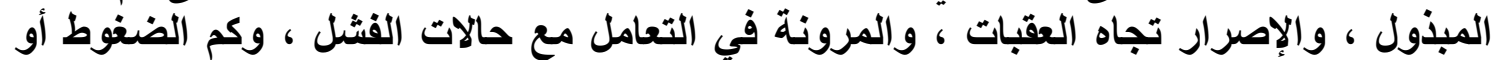

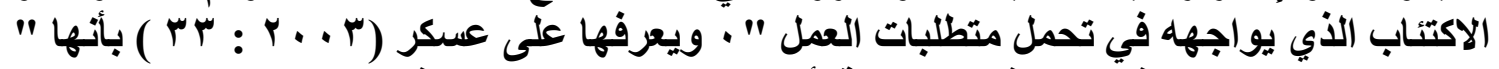

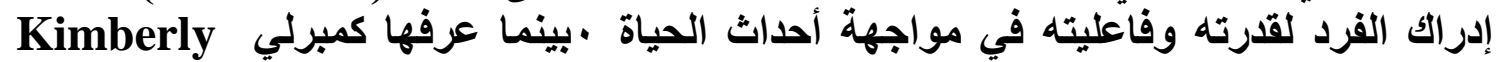

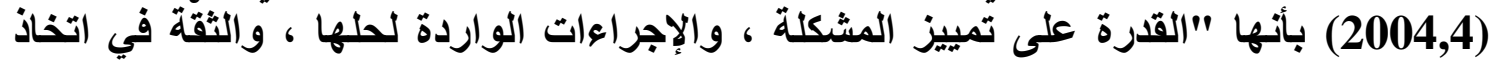

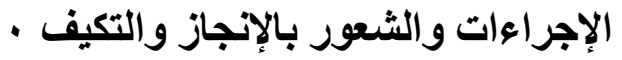

تعرفها الباحثة إجرائًا بأنها : ثقة الطالبة المعلمة شعبة فلسفة واجتماع في قدرتها على أداء و

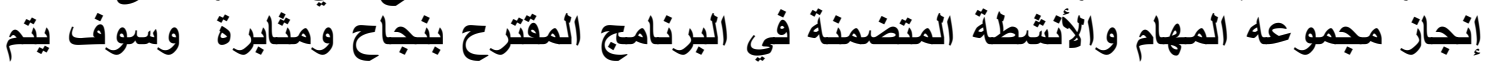

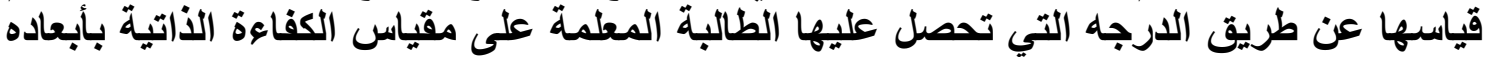

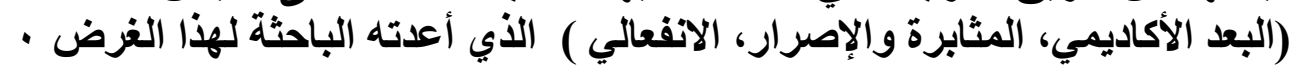

\section{بقاء أثز التعلم}

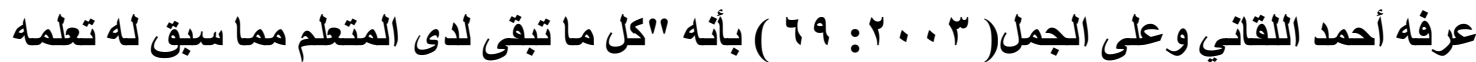

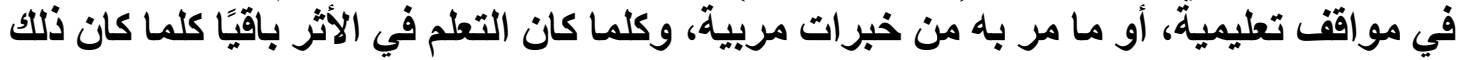

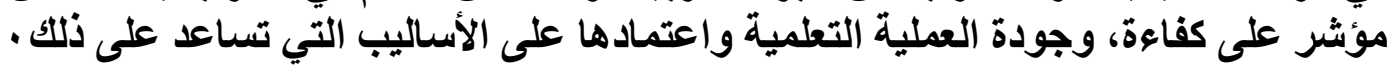

يعرف إجرائيًا بأنها: قرة الطالبة المعلمة على استرجاع المفاهيم المنطقية المتضمنة في البرنامج

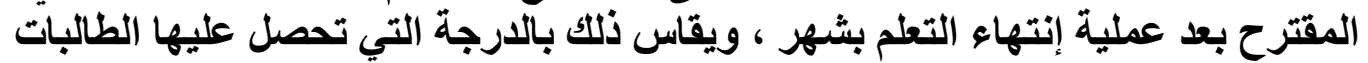

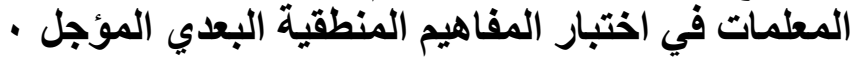


للإجابه عن تساؤلات البحث ، و الكثف عن مدى صحة فروضة سوف تتبع الباحثة الخطوات الآ

إعداد قائمة بالمفاهيم المنطقية الأساسية اللازمة البمة للطالبة المعلمة شعبة فلسفة واجتماع ، وذلك

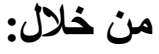

اـ تحليل محتوى كتب المنظق و الفلسفة للفرق الثثلاثة للمرحلة الثانوية العامة .

r ـ فحص مقررات الإعداد الأكاديمي في برنامج إعداد الطالبة المعلمة لثعبة المواد الفلسفية.

بـفـص بعض الكتب والمراجع الأكاديمية في مجال المنطق لتحديد المفاهيم المنطقية الأساسية

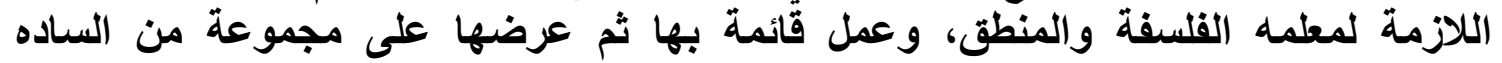

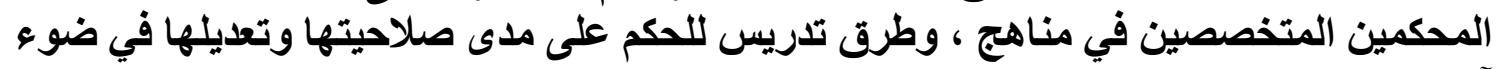

$$
\text { ץ ـ للإجابة عن السؤال الثاني من أسئلة البحث سيتم الآتي: }
$$

ـ بناء البرنامج المقترح القائم على نموذج فراير لتنمية المفاهيم المنطقية الأساسية اللازمة لاى

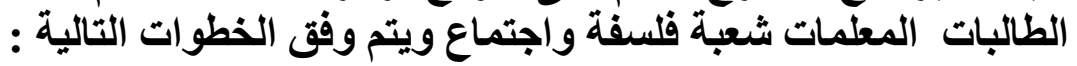

أ-تحديد أهداف البرنامج المقترح ·

ب-تحديد أسس بناء البرنامج المقترح ·

ج-تحديد فلسفة البرنامج المقترح -

د-إعداد دليل المعلم وأوراق الخاص بإجراء تدريس البرنامج المقترح •

هـ إعداد أدوات البحث ، و التأكد من صدقها وثباتها وهى عبارة عن (إختبار في المفاهيم المنطقية

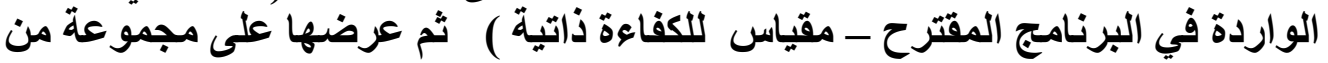

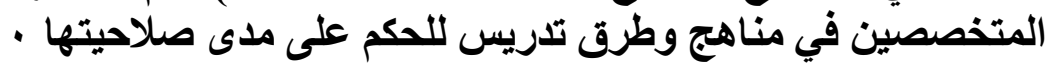

r ـ للإجابة عن السؤال الثالث والرابع والخامس من أسئلة البحث سيتم الآتي :

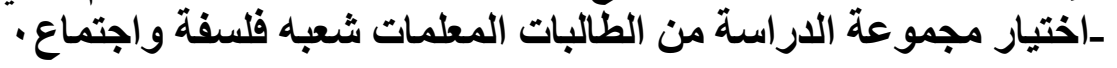

ـتطبيق أدوات البحث على مجموعة الدراسة تطبيقًا قبليًا.

- تلدريس البرنامج المقترح للطالبات المعلمات شعبة فلسفة واجتماع -

ـ تطبيق أدوات البحث على مجموعة الدراسة تطبيقيًا بعديًا. 
-رصد النتائج وتحليلها وتفسيرها ومناقشتها في ضوء فروض البحث وأسئلته . -تقديم التوصيات و المقترحات في ضوء نتائج البحث . الإطار النظري للبحث:

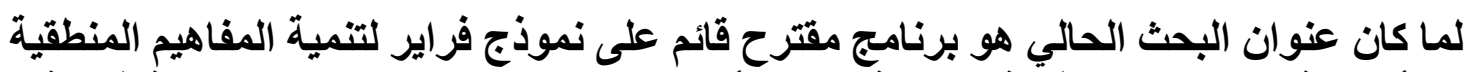

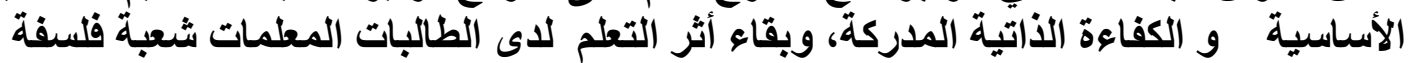
والاجتماع فقد تتطلب ذللك أن يتضمن الإطار النظري للبحث الحالي المحاور التالية :

$\checkmark$ • ل المفاهيم المنطقية

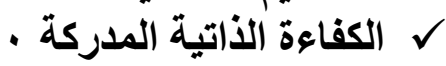
نموذج فراير

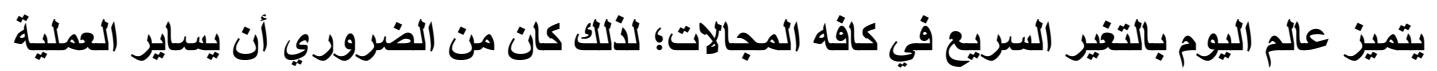

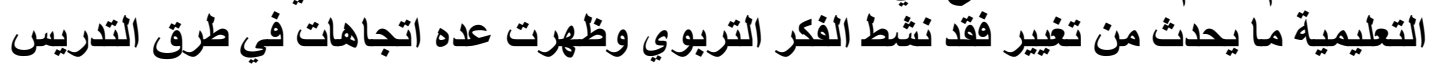

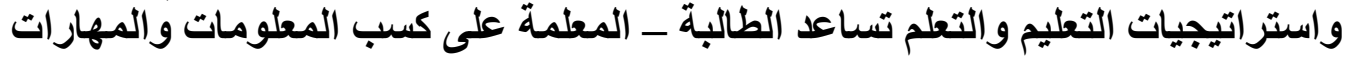
و والمفاهيم والاتجاهات من خلال المرور بمواقف تعليمية متنوعة ومنها التعلم النشط .

والتعلم النشط Active Learning مصطلح ظهر في السنوات الأخيرة من القرن العشرين

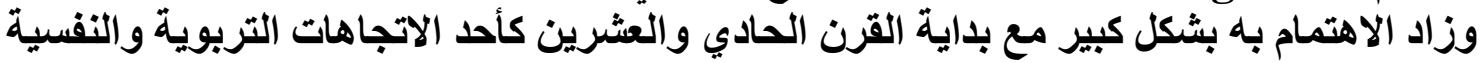

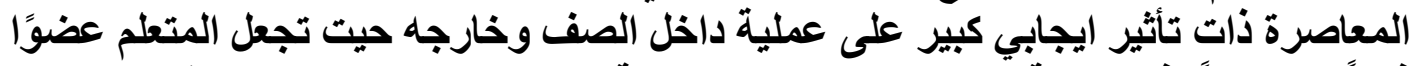

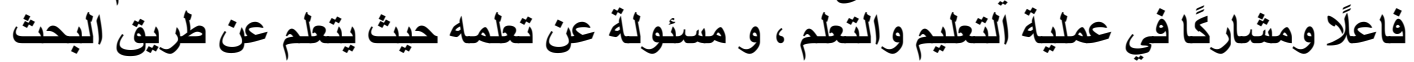

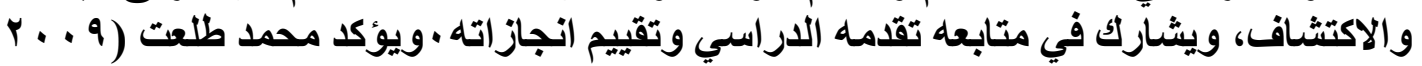
0) إن جان بياجيه ويفسر التعلم النشط لدى المتعلم من خلال عمليتين هما :

1 ا_الملاعمة :وتختص بما يجري داخل البناء العقلي ،أو التراكيب الموجودة لاى المتعلم من

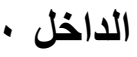

r التمثيل والاستيعاب : وهى عملية تتثكل نتيجة العوامل الحسيـة والاجتماعية الموجودة خارج

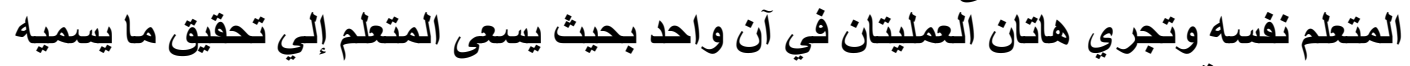
بياجيه بعملية التوازن ونجري هان

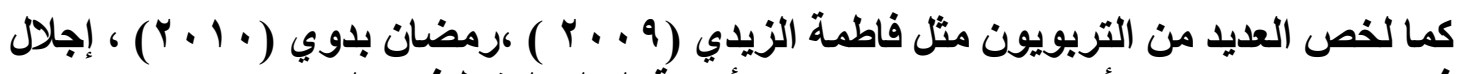

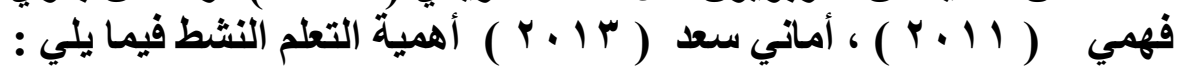

ا - يهيبيء للمتعلم مواقف تعليمية حية .

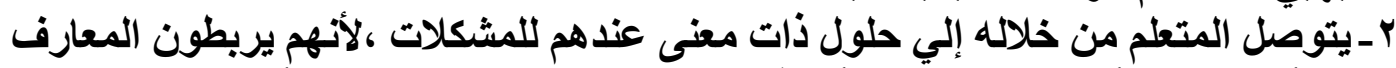

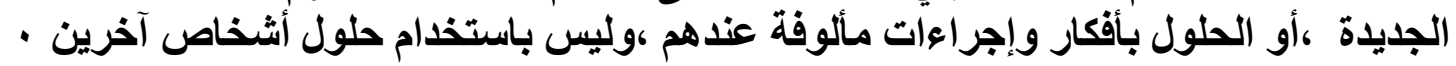
بـ-يزيل من اندماج المتعلم في العمل حيث يحصل المتعلمون من خلاله على تعزيزات كافية حول

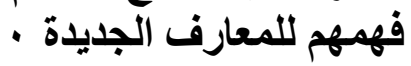


؛ -يحسن من دافعية المتعلم نحو التعلم ·

هـينمي لاى المتعلم الرغبة في التفكير والبحث والتعلم حتى الاتقان •

\-يبين للمتعلمين قدرتهم على التعلم بدون مساعدة ، و هذا يعزز ثقتهم بذواتهم والاعتماد على

Vيساعد المتطلم على استرجاع المعلومات من الذاكرة ربما لأكثر من موضوع مع ربطها بعضها

هذا وقد انبثقت من التطلم النشط استراتيجيات تدريس ونماذج عديده اهتمت بتعلم المفاهيم

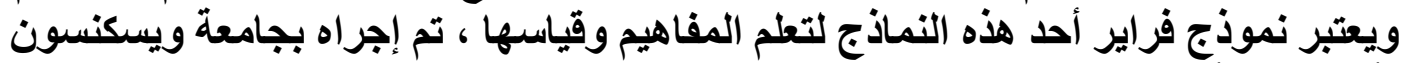

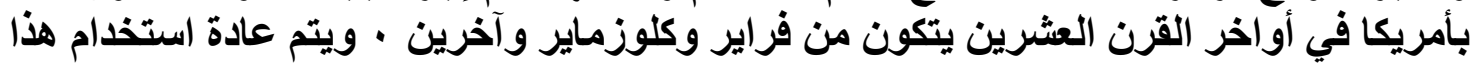

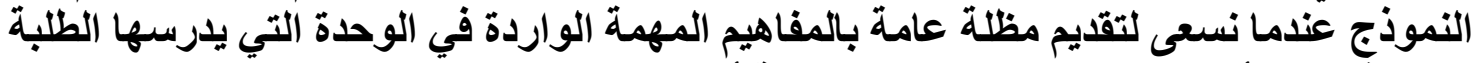

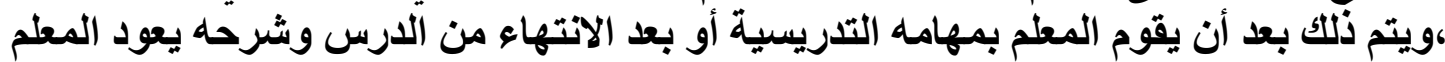

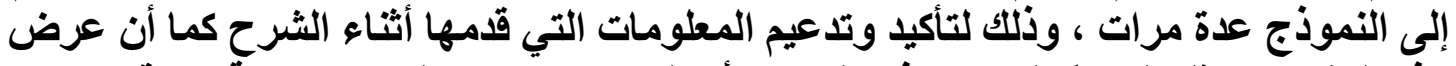

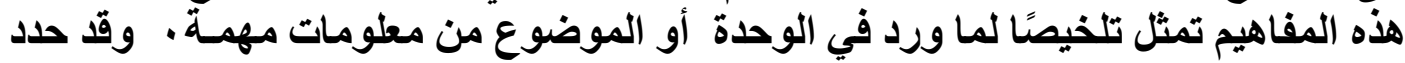
فراير إجراءات محدة لتعليم المفهوم وفقا للخطوات الآنية:

ا.تحديد المفاهيم الرئيسة بالوحدة وعلاقتها بالمفاهيم الأخرى المرتبطة بها.

r. توضيح مدى الاتفاق أو الاختلاف بين المفاهيم الجديدة ،والمفاهيم التي يمتلكها الطلبة بالفعل. r. تقديم مجموعة من الأمثلة الثارحة و المفسرة للمفهوم الجديد.

؛. تقديم مجموعة من الأمثلة الخالية من هذا المفهوم لتحديد المفهوم الذي يدرسد الطلبة.

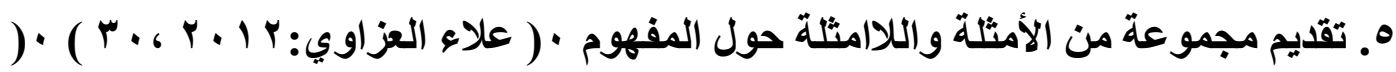

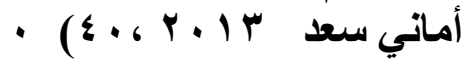

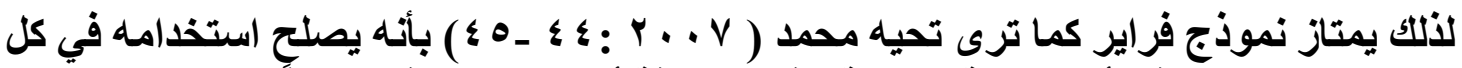

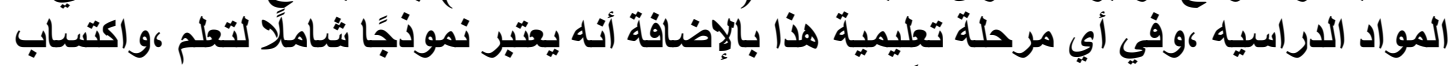

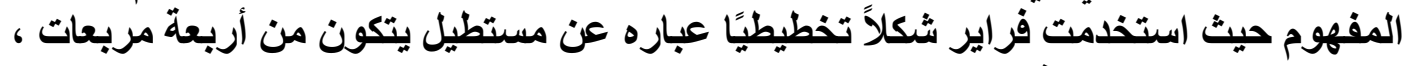
يتوسطها اسم المفهوم في دائرة كما يلي : 


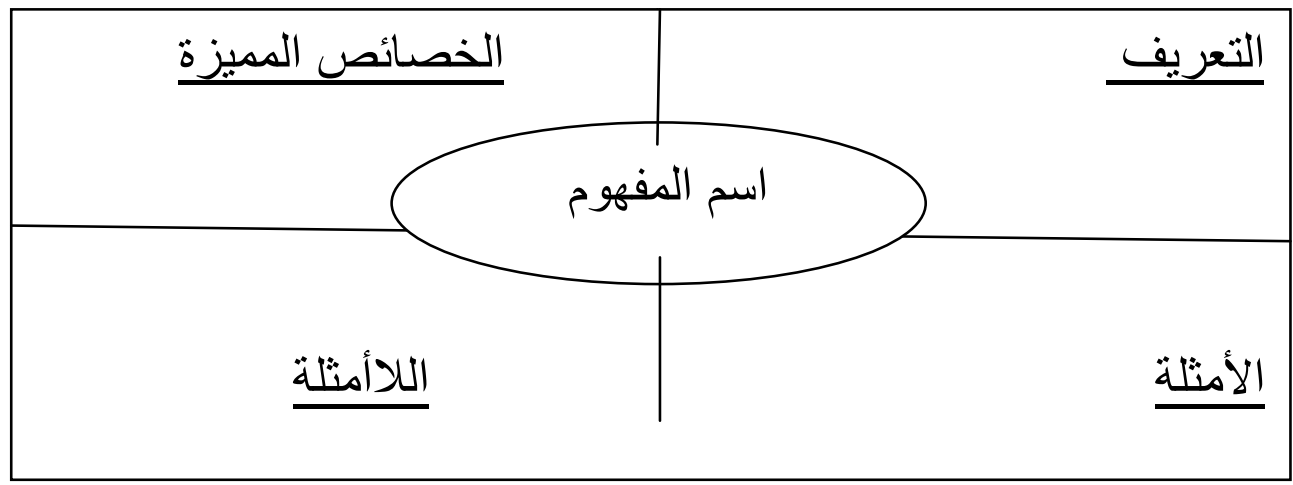

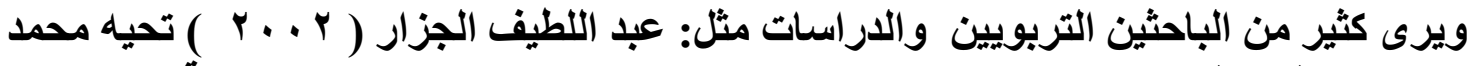

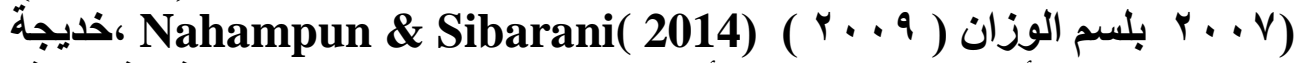

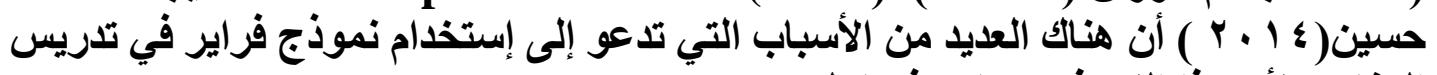

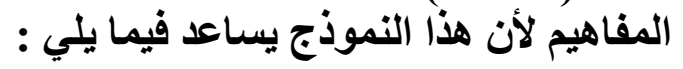

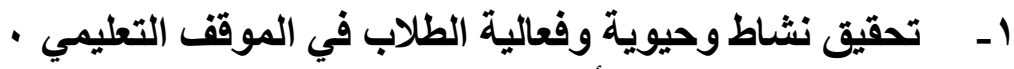

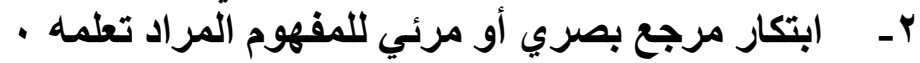

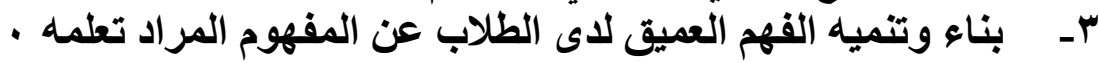

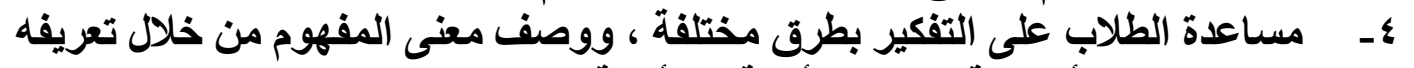

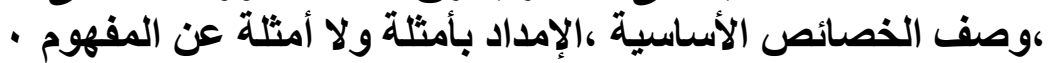

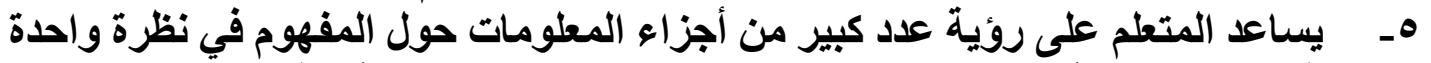

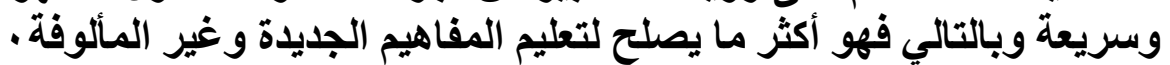

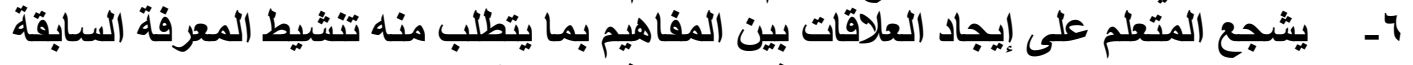

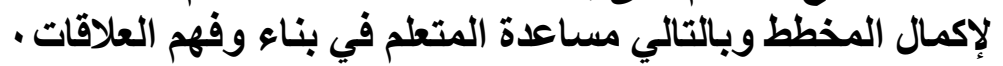

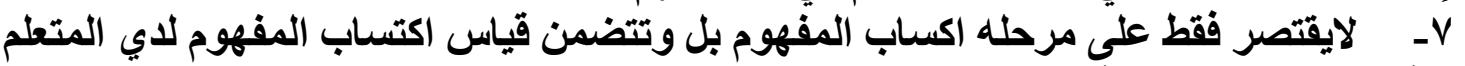

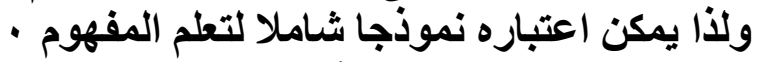

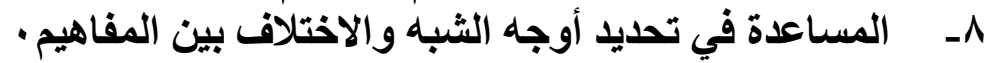

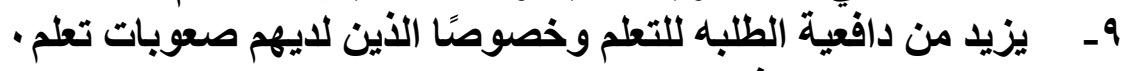

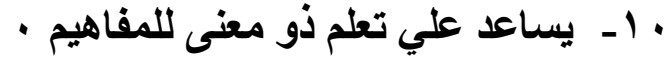

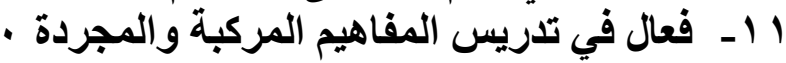

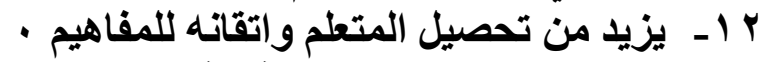
ومن الدراسات التي اهتمت بنموذج فراير :

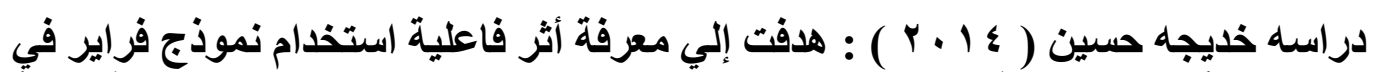

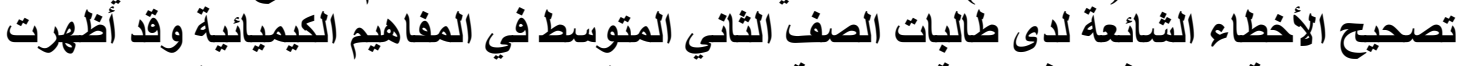

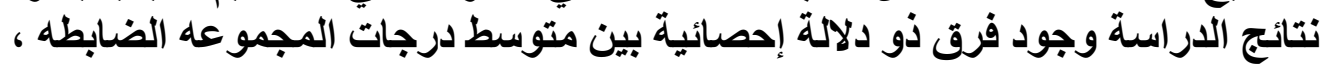

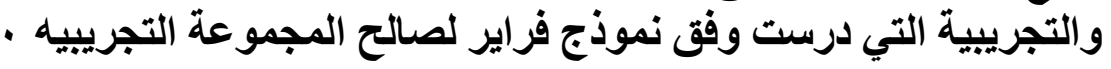

دراسة وصال هاني (7 1 ـ r ) : التي هدفت إلى التعرف على أثر استخدام نموذج فراير في

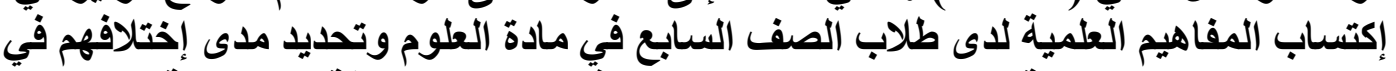

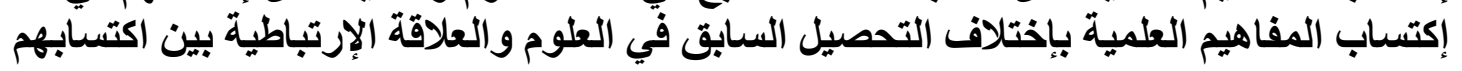


للمفاهيم ، وإتجاهاتهم نحو التعلم وقد أظهرت النتائج فاعلية النموذج في إكتساب المفاهيم ، إنهاتئ

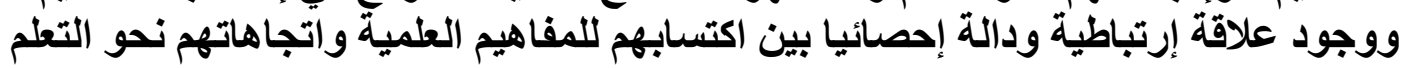

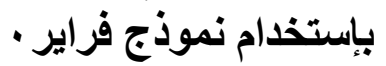

دراسة ( 2015, ILter) :هدفت إلي تحديد أثر نموذج فراير في تطوير مفردات في الدراسات

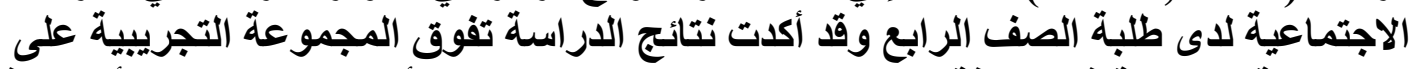

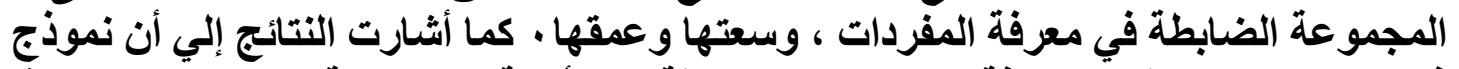

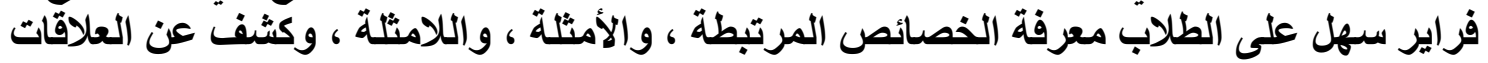

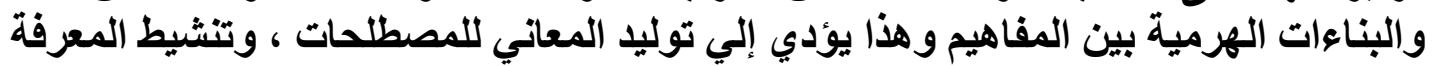

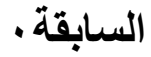

\section{المفاهيم المنطقية}

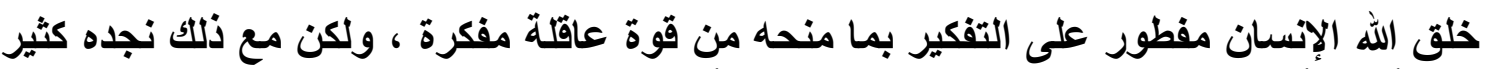

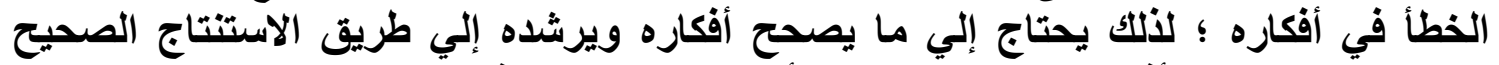

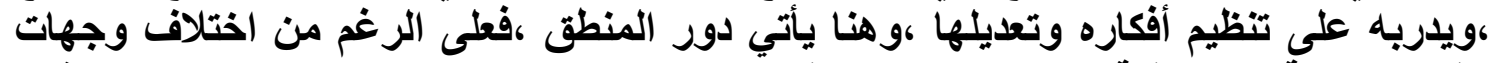

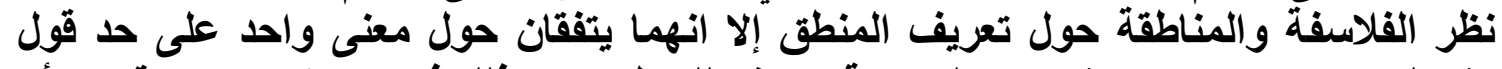

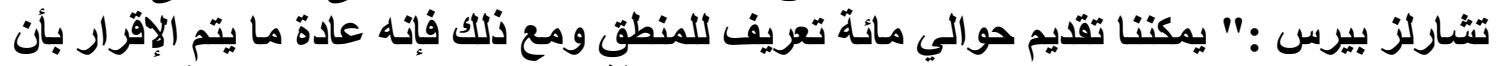

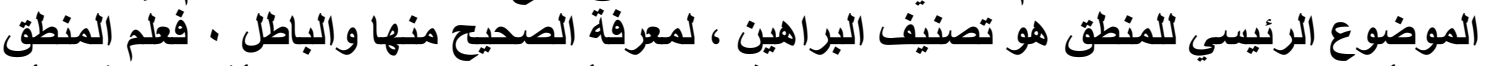

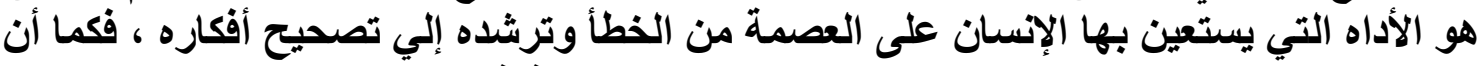

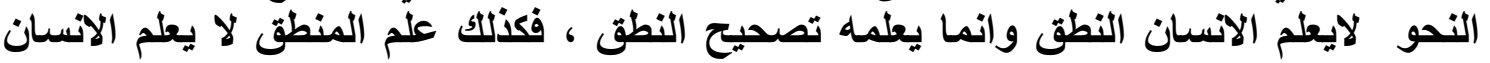

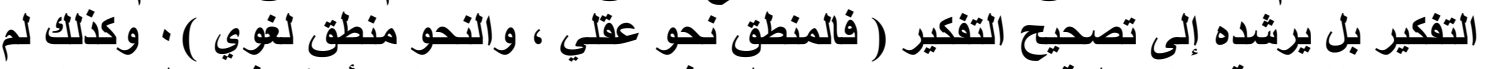

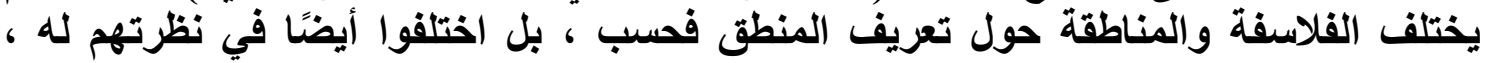

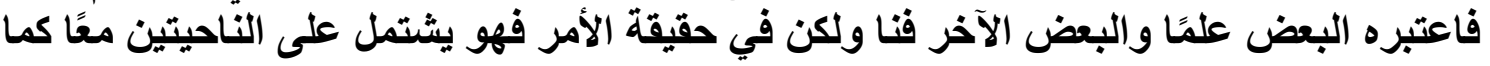

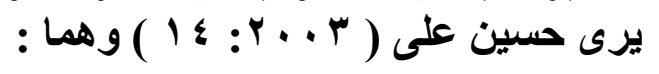

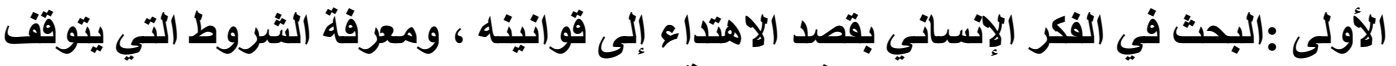

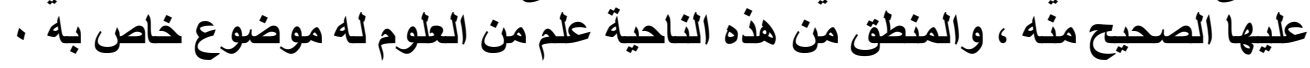
الثانية : تطبيق هذه القوانين على أنواع الفكر المختلفة؛ لمعرفة الصواب منها والخطأ، والمنطق

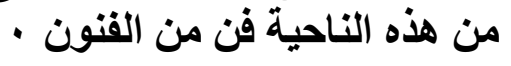

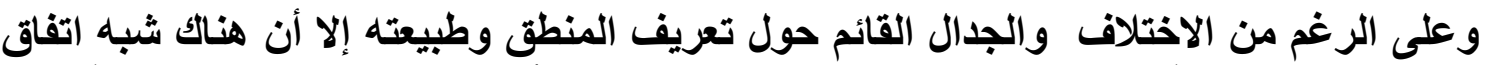

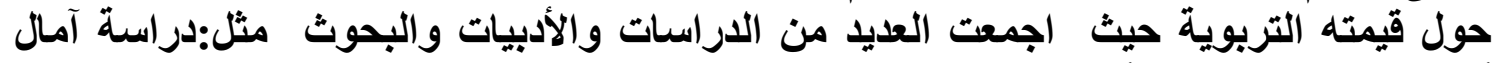

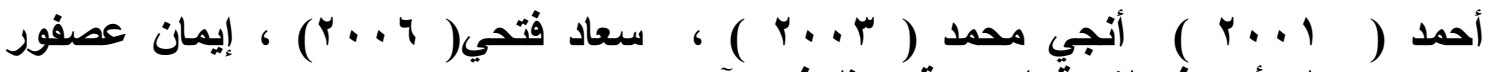

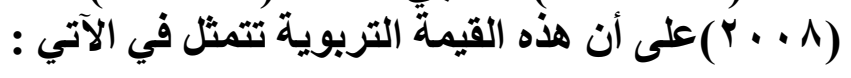

إينمي المنطق لاى الدارس قدرات عقلية مختلفة مثل :القدرة على التذكر ، والقدرة على الإلى

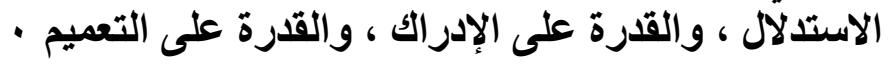

r-يكسب دارسة انماط تفكير سليمة ؛لمواجهة ما يحدث في مجتمعهم من تغيرات وتطورات . 


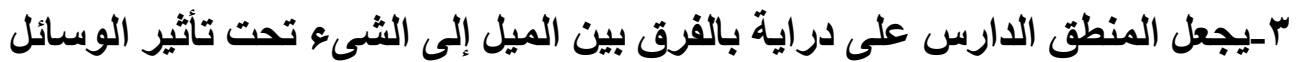

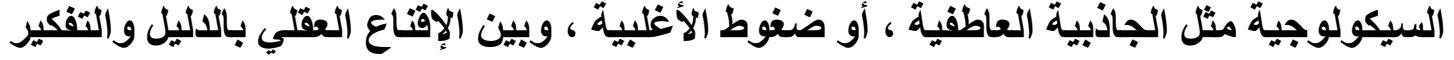

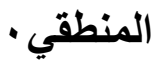

ع ـالتدريب على كيفية الاستدلال على النتائج من شتى المقدمات الممكنة بالطرق العقلية المتنوعة

هـتربية الروح العلمية والتعود على استخذام الأسلوب العلمي والموضوعية في شتى مظاهر

\-تذريب الطلاب على التعبير عن أفكارهم بوضوح وبطريقة مبسطة .

- Vكسب الدارسين القدرة على النظر والفحص والنقا والقدرة على التحليل الصحيح والمنطقي.

1_المنطق لايعلم الطالب كيف يفكر وحسب ، بل كيف ينبغي أن يفكر وأن يتدرج من المقدمات إلى الى

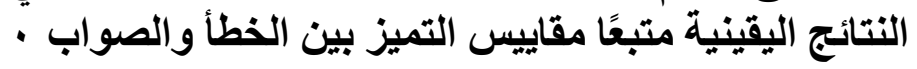

9 ـ يمد المنطق الطالب بالقواعد والنواحي الفنية التي من خلالها يقيم نتائج تفكيره حيث يعطيه

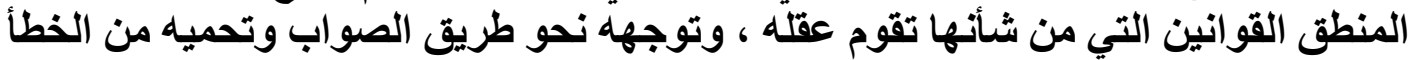

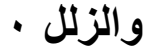

• إيمد الطالب بالقدرة على تعريف الأثياء وتحديدها ، ويساعده على الكثف عن المغالطات

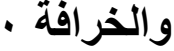

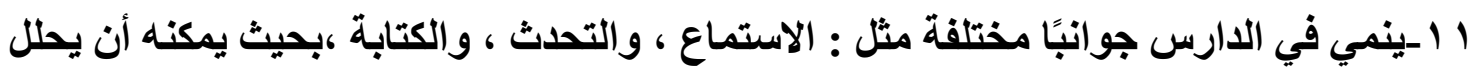

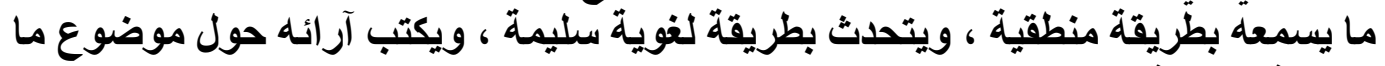

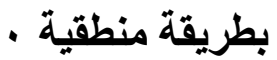

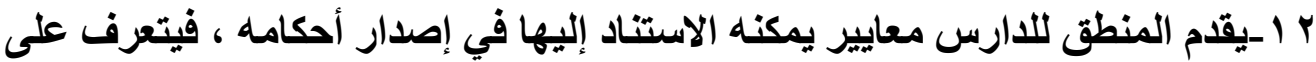

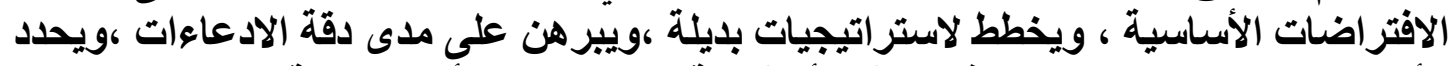

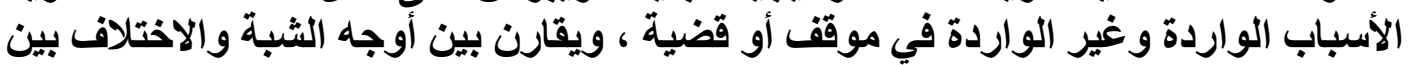

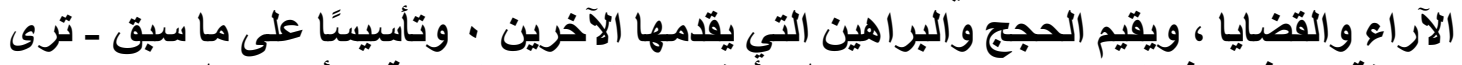

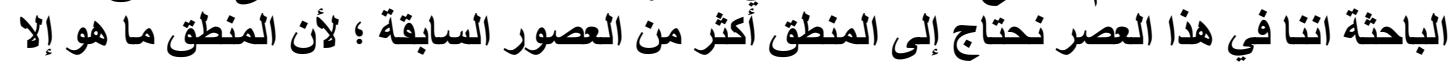

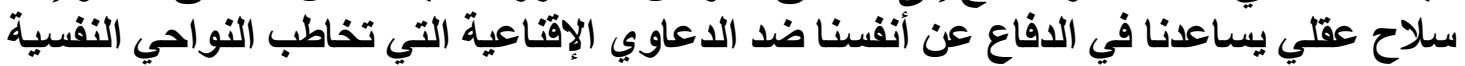
والتي تحيط يوميا بنا في وسائل الاعلام المختلفه .

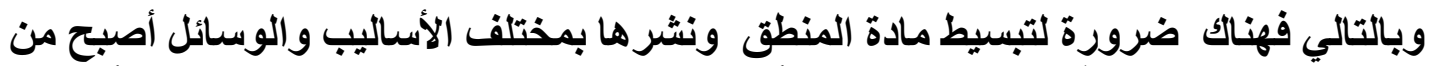

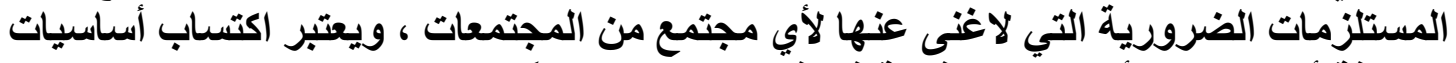

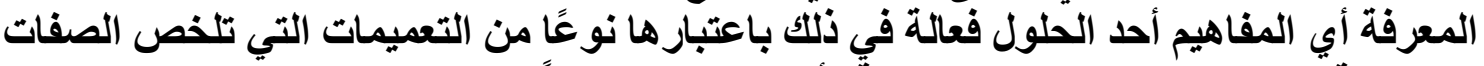

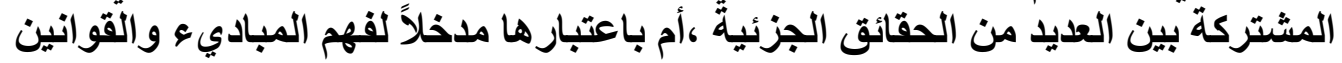

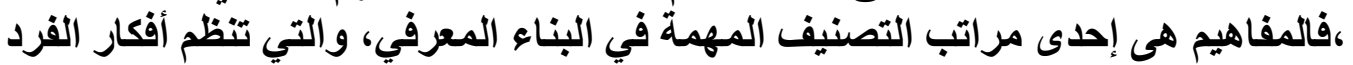

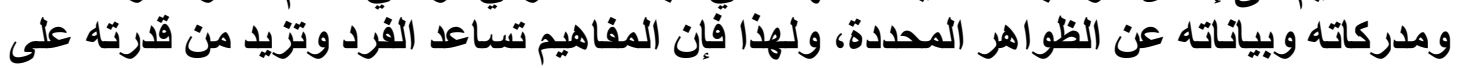


تعلم كمية غير محدودة من أساسيات المعرفة ـهذا وتنقسم المفاهيم في المنطق إلى نوعين بناء

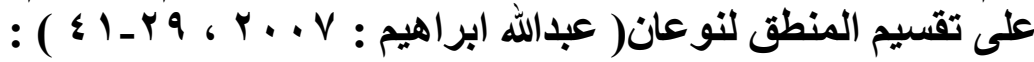

ل المنطق الصوري( الثكلي) : هو ذللك الفرع من المنطق الذي يبحث في صورة الفكر دون

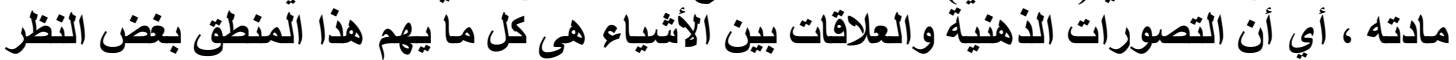

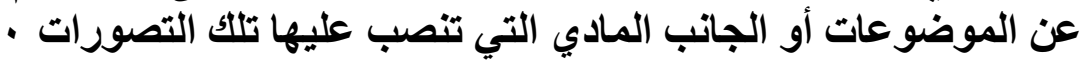

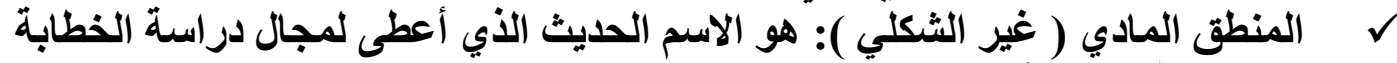

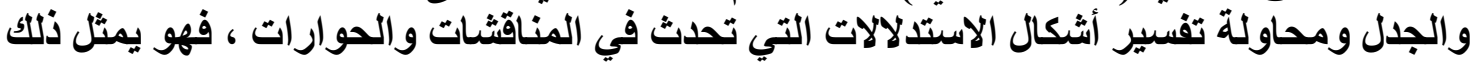

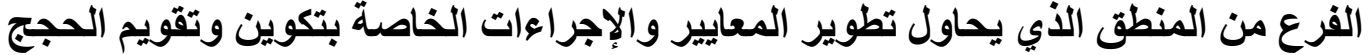

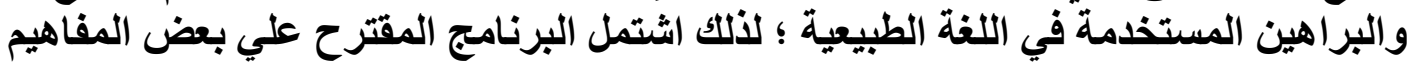

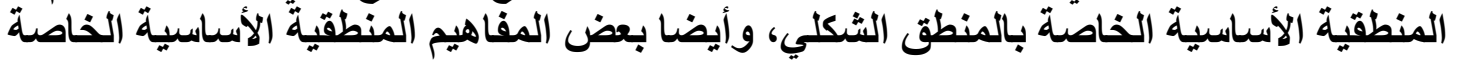

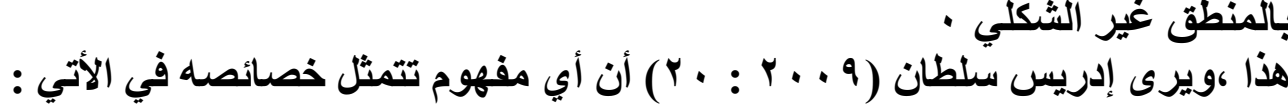
1 - التجريد : فهناك المفاهيم الحسية و المفاهيم المجردة .

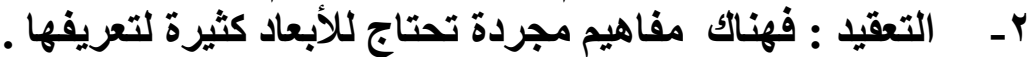

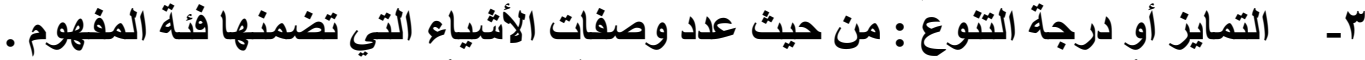

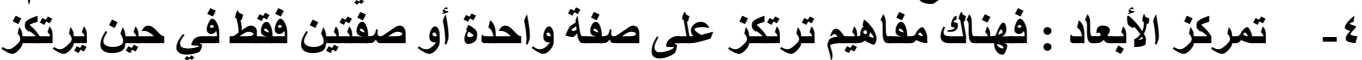
البعض الآخر علي مجموعة من الآبعاد أو الصفات التي ترتكز عليها المفهوم تسمي الصفات

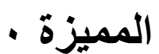

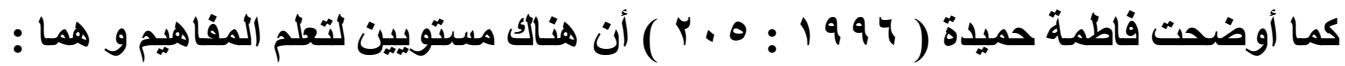
المستوي الأدني : و يعبر عن قدرة الفرد في التمييز بين الأمثلة المطابقة الموجبة و الأمثلة غير المطابقةً السالبة للمفهوم • المستويات الأعلّي و تعكس قدرة الفيز الفرد في كلا من :

\section{ه التعريف المحدد للمفهوم بخصائصه .}

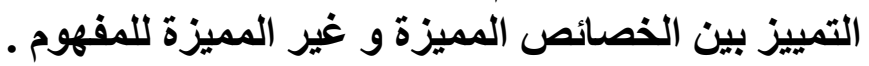

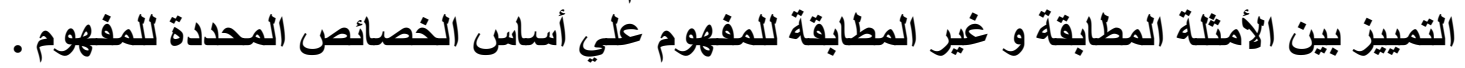

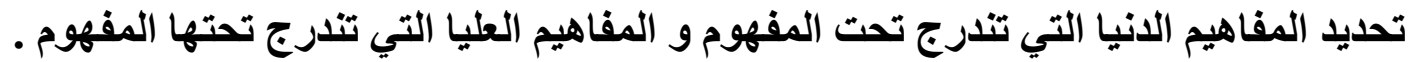

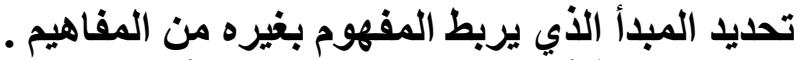
وترى الباحثة أن نموذج فراير استطاع أن يجمع بين تعلم المستويين و يتضح ذلك من خطواته .

حيث يمكن الطالبة المعلمة من تعلم المفهوم المنطقي من خلال :

1ـ التعبير اللفظي عن المفهوم : و هذا يتضمن معرفته بمضمون المفهوم و أبعاده و ما يال عليه

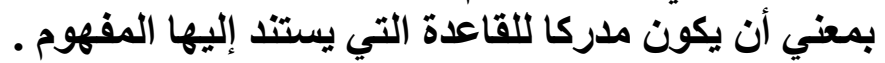

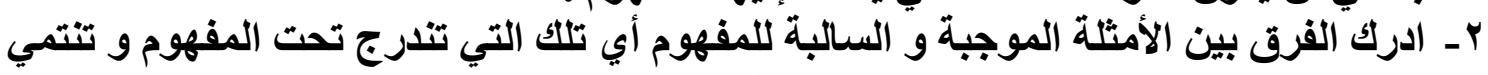

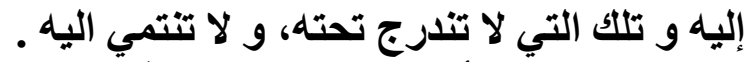

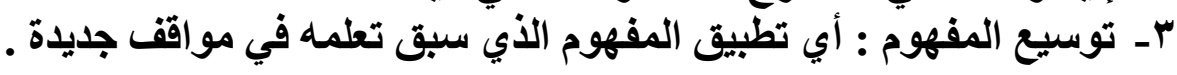

؛ -إدراك العلاقة الهرمية بين المفهوم و غيره من المفاهيم · 


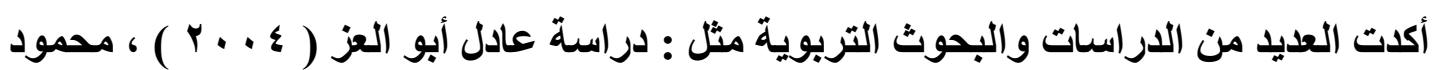

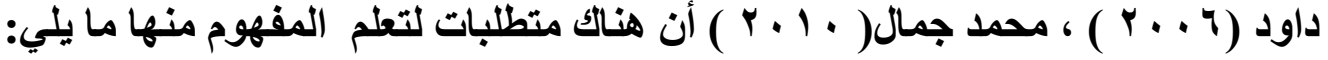
أ ـالمفهوم عمليات عقلية استدلالية، وبالتالي يتطلب أن يصل المتعلم لمراحل نمو العملية العقلية

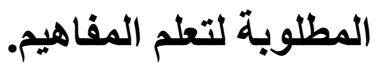
ب -يتطلب تعلم المفهوم عمليات التمييز : كالتمييز بين أمثلة المفهوم ولا أمثلة. ج -الأداء الدال على تمكن المتعلم من تعلم المفهوم، وهو قدرته على ولى تصنيف الأمثلة، ويتطلب تدريب المتعلم بصورة جيدة، وإعطاؤه عددًا لا بأس به من الأمثلة والكلا أمثلة التدريبية. دـ ـتعلم المفهوم ينتظم في سلم هرمي، ويتطلب التأكد من مستوى المتعلم ووصوله للعمليات

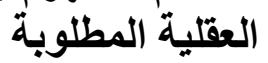

هـ تهيئة الظروف المناسبة لمساعدة المتعلم على تعلم المفاهيم وتحقيق الأهداف المطلوبة.

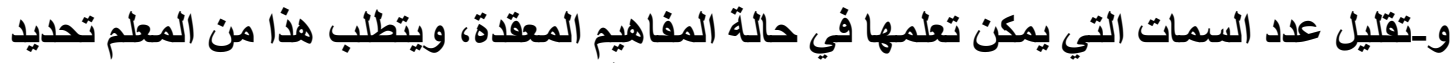

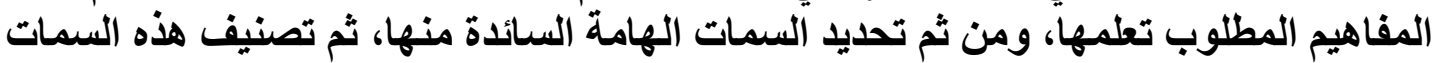

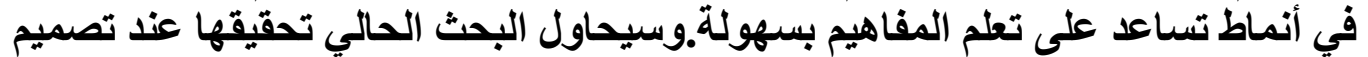

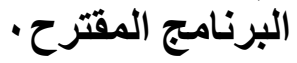

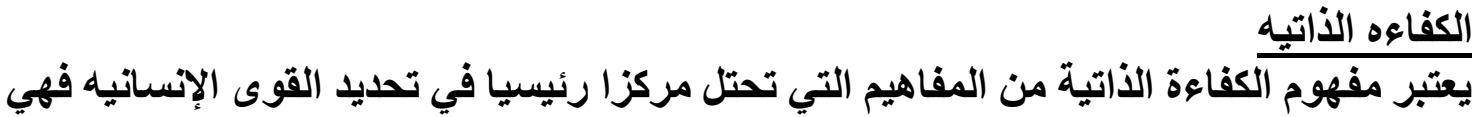

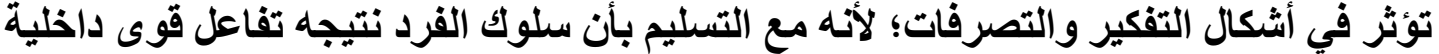

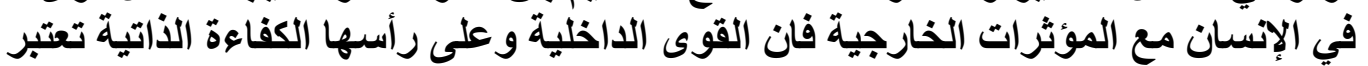

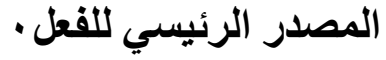

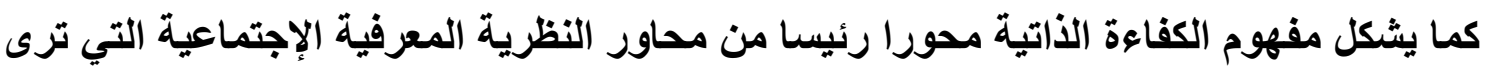

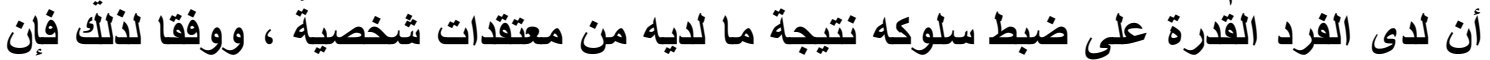

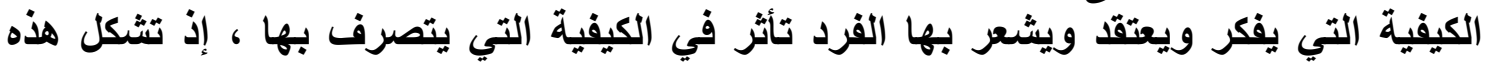

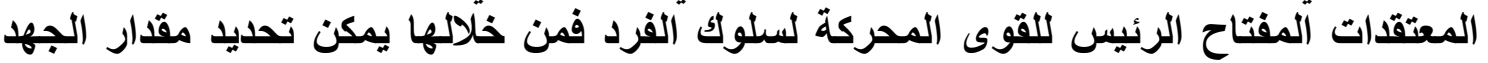

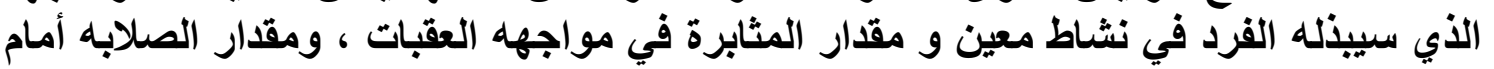

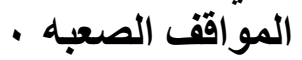

فالكثف عن الكفاءة الذاتية المدركة يعد من أهم الأسس التي يقوم بها العلاج العقلاني

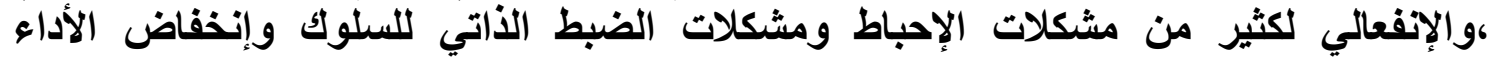

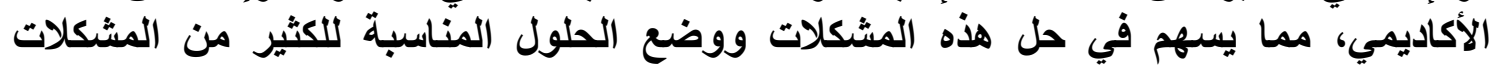

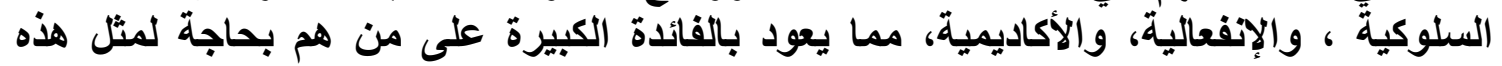

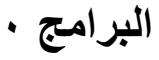

هذا ومن الجدير بالذكر أن هناك تعريفات عديدة للكفاعة الذاتية منها على سبيل المثال وليس 
عرفه (3: 2000, ) Pajares بأنها " معتقات الفرد عن قدراته على تكوين وتنفيذ سلسلة من الإنجازات المطلوب تحقيقها في بعض المواقف المتنوعة " .

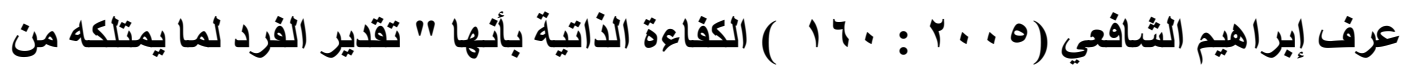

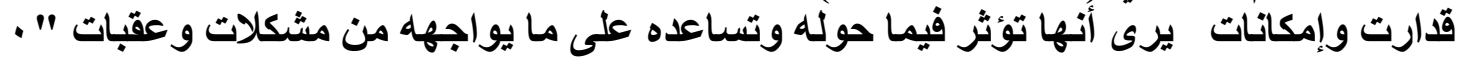
عرفه ( Palmer, 2006 ) إنها "قدرة الطالب الواقعية على تحقيق هدف ماو هذه القداء القدرة من الممكن تقويتها لجعله أكثر قدرة على الأداء الناجح في المواقف المعت المستقبلية" .

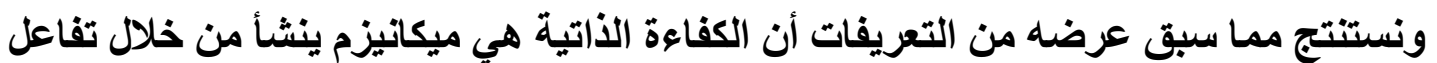

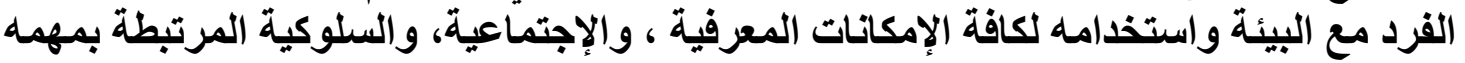

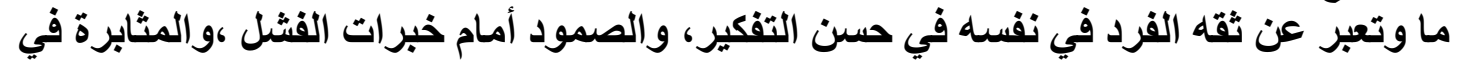

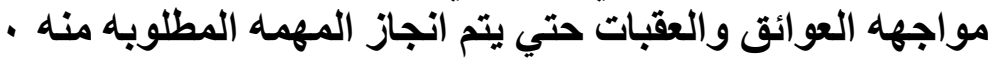

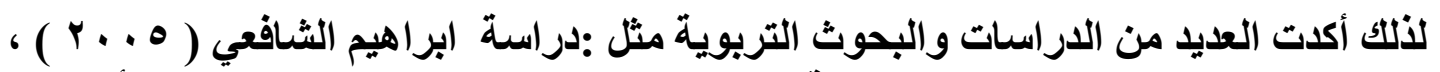

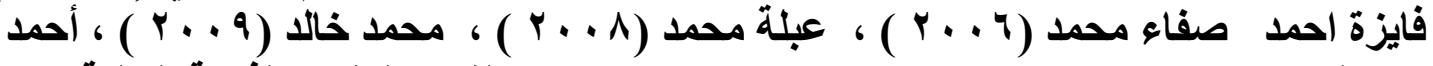

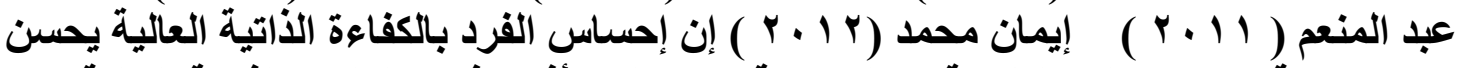

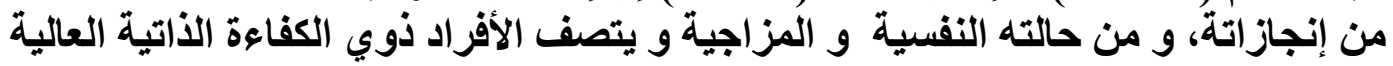

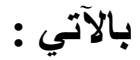

1 - لايهم ثقة عالية في قدراتهم حيث ينظرون إلي المهام الصعبة التي تواجههم على أنها تحديات

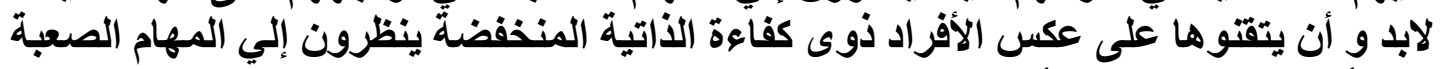

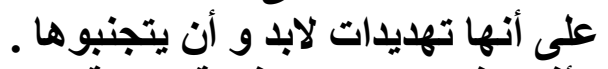

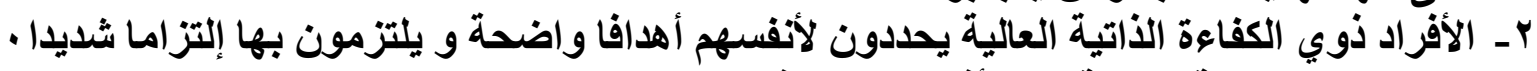

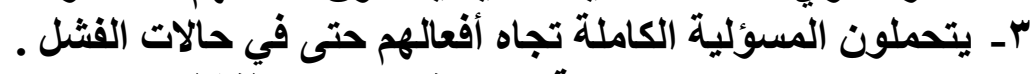

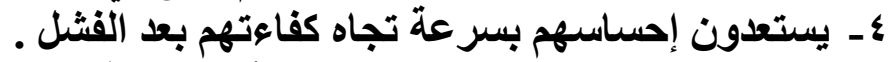
هـ ينسبون الفشل إلى الجها غير الكافي أو المعرفة و المهارات الناقصة لذألك فهم دائما يطورون

$$
\begin{aligned}
& \text { أنفسهر . }
\end{aligned}
$$

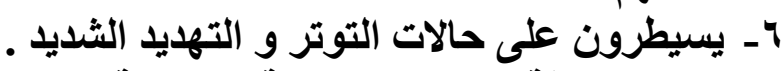

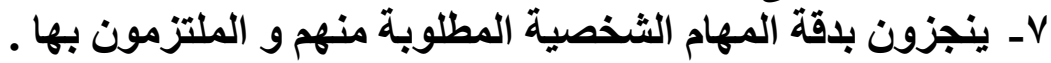

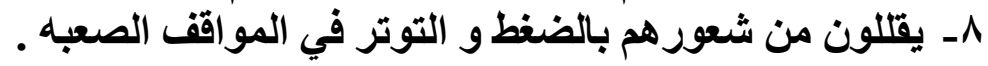

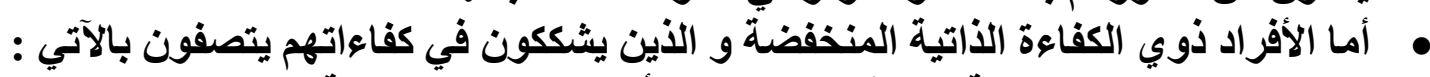

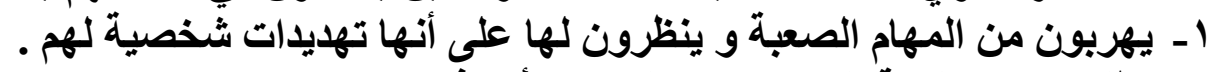

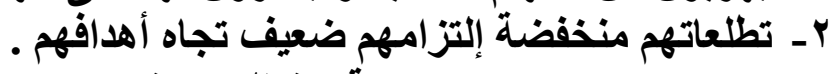

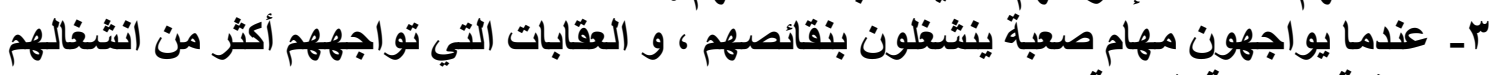

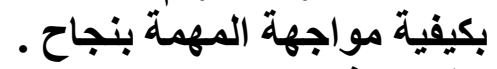

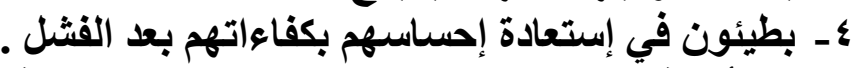

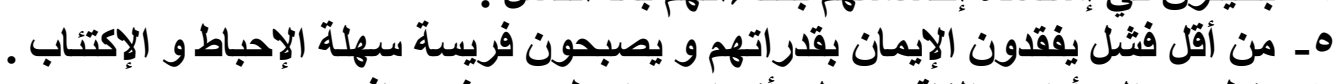

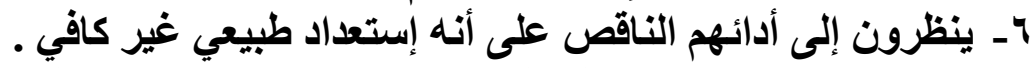

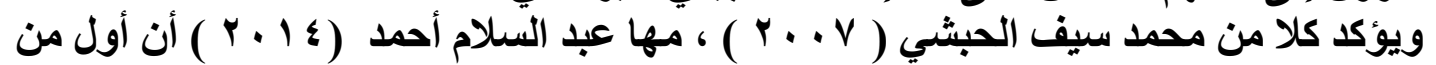

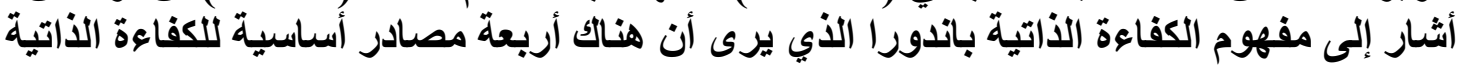




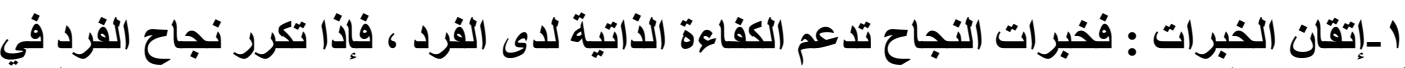

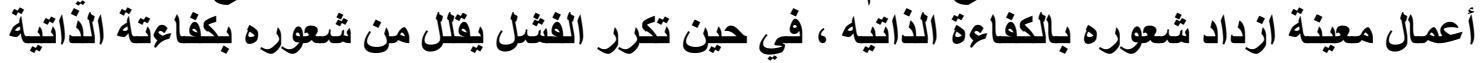

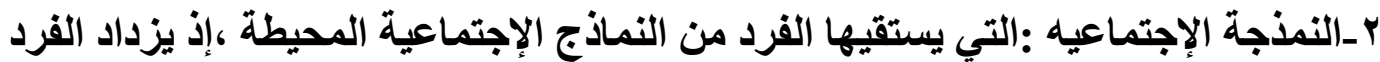

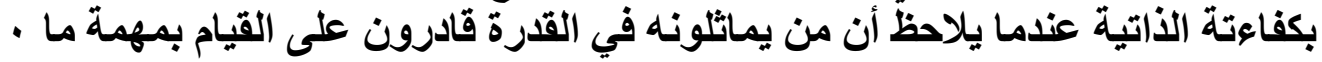
بـالإقتاع الاجتماعي : فمعتقدات الكفاءة الذاتية تتأثر بالإقتاع الأي يتلقاه الفرد من بعض

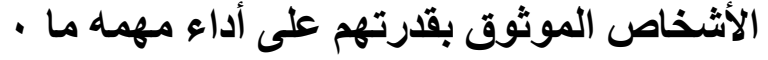

ع -الإستجابات النفسية :فالكفاعة الأتية تتأثر بمستوى الإستثارة الإنفعالية ، فالإثارة الإنفعالية

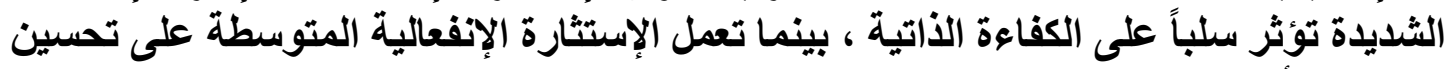

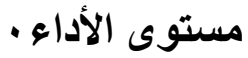

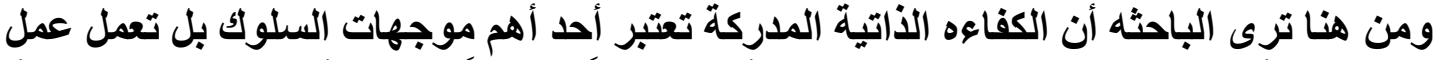

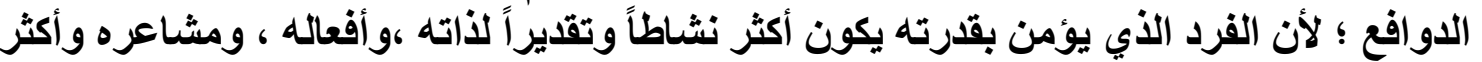
ثقة بالنفس في مواجهة الضنوط النفسية ، و والحياتيه .

ويؤكد ( Bandura , 2007 ) أن هناك ثلاثه أبعاد تتغير الكفاعة الذاتية تبعا لها وهذه الابعاد هی :

اـقار الكفاعة الذاتية :وهو يختلف تبعا لطبيعة وصعوبة الموقف ويتضح عندما تكون المهام

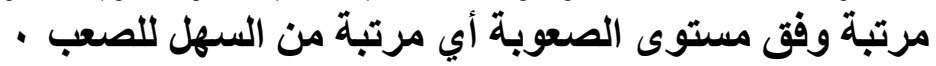

بـا_العمومية :هى إنتقال فاعلية الذات من موقف إلى مواقف مشابهاه ، فالفرد يمكنه النجاح في

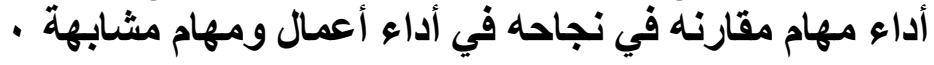

بـالقوة والثدة : يؤكد باتدورا على أن قوة الثعور بالفاعلية الثخصية تعبر عن المثابرة العالية

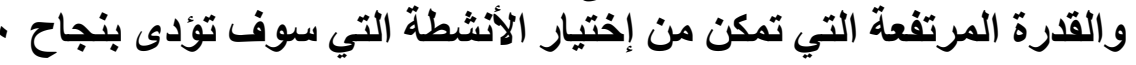

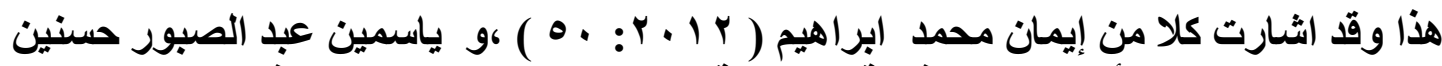

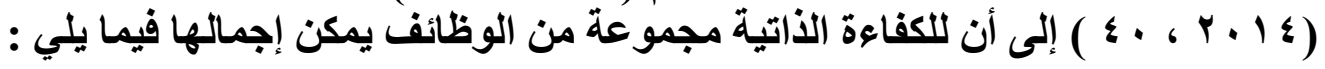

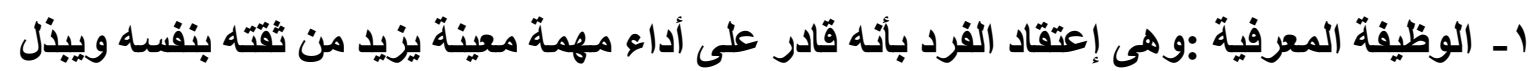

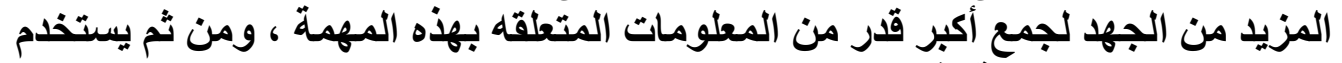

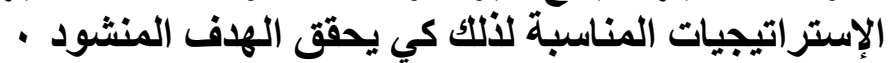

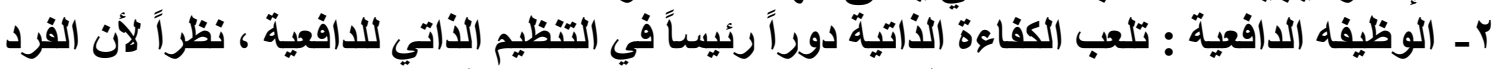

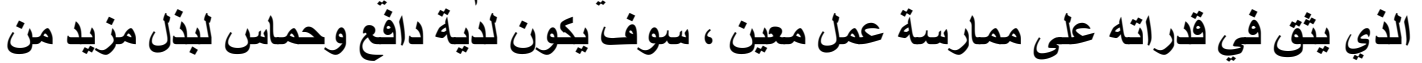

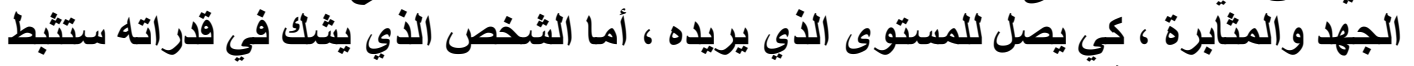

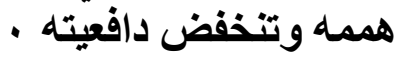
rــ الوظيفة الإففعالية : للكفاعة الذاتية دوراً مهماً في التظلب على الكثير من المشكلات الإنفعالية التي

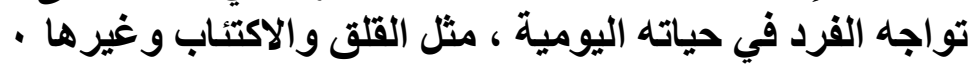

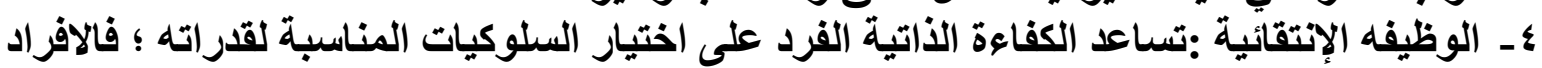

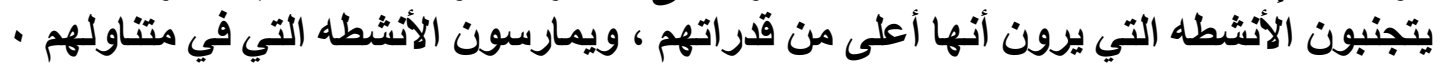




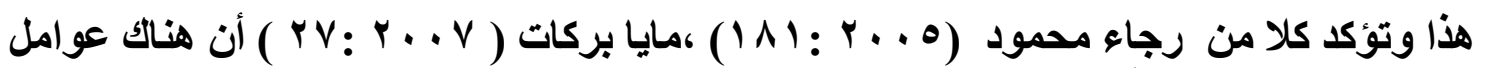
تؤثر في الكفاءة الذاتية وهى :-

ا-خبرات النجاح والفشل : فخبرات النجاح تلدم الكفاعة الذاتية لاى الفرد في حين أن تكرار

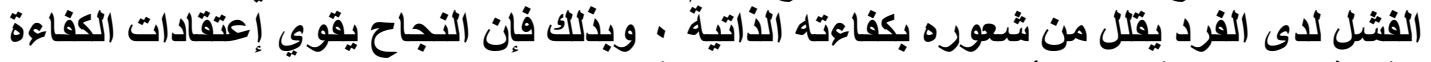

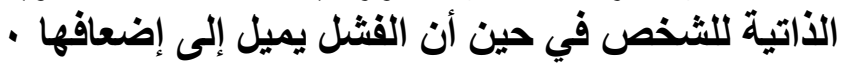

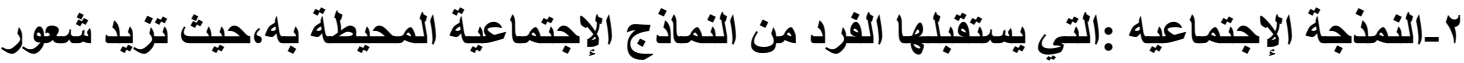

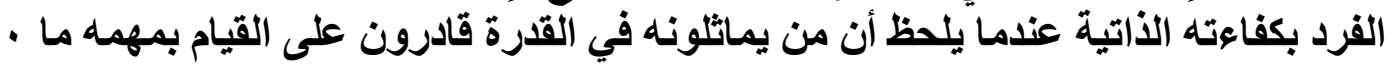

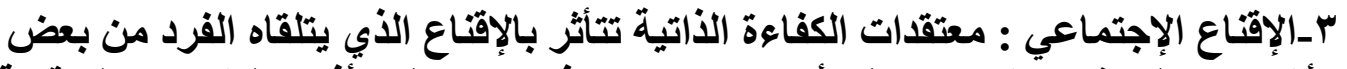

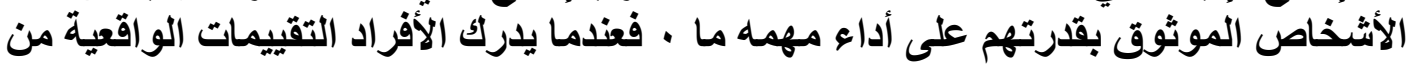

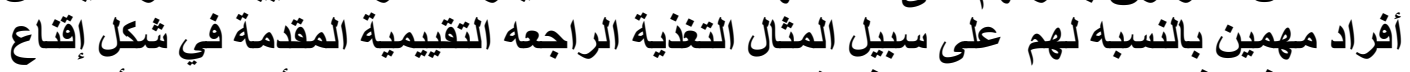

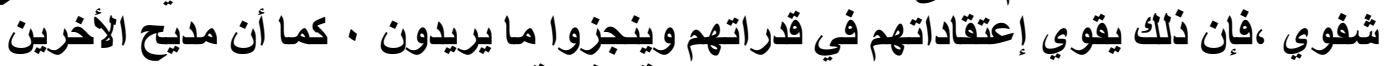

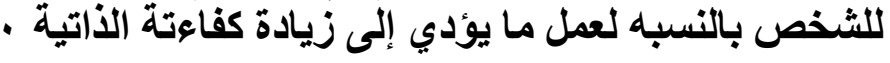

ع -الإستثارة الإنفعالية :أن الحالات العاطفية تؤُثر على إعتقادات الكفاءة الذاتية لاى الأفراد

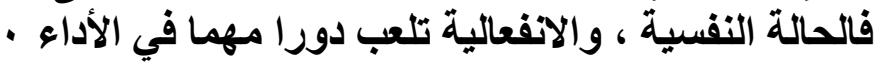

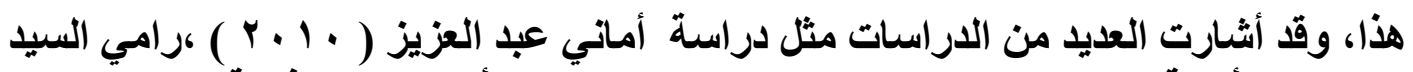

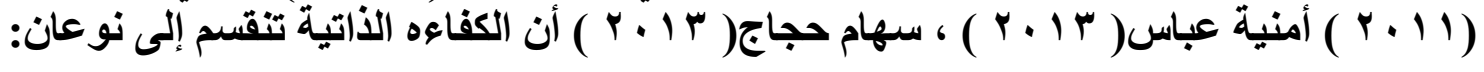

ا ـالكفاءة الأكاديمية : مجموعة من المهارات والسلوكيات الضرورية لتحقيق النجاح الأكاديمي

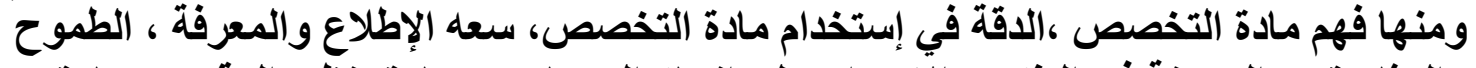

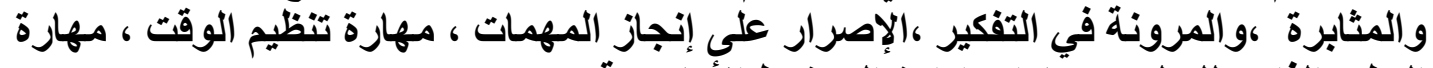

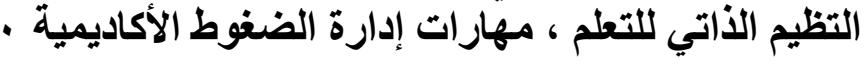

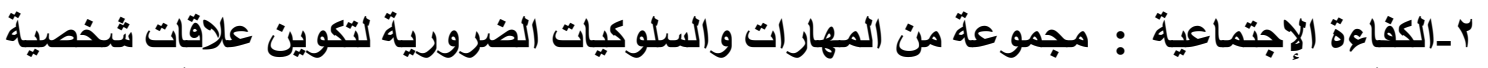

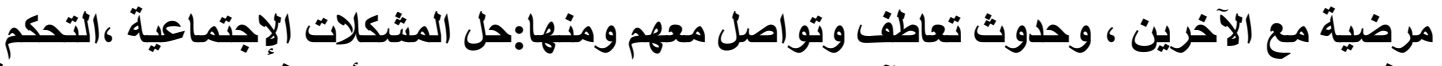

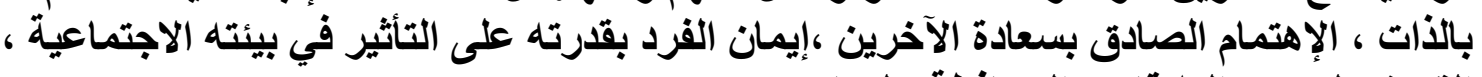

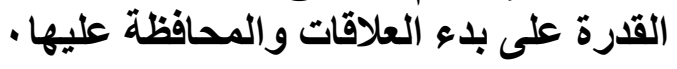

لذلك يرى جمال عبدالله زيتون (9 . . Y : Y م) أن هناك متطلبات للكفاعة الذاتية تتمثل في : متطلبات عقليه خاصه بالتفكير : مثل مهارات التفكير الاستقصائي ، المرونة في المواقف

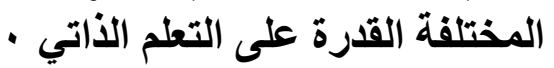

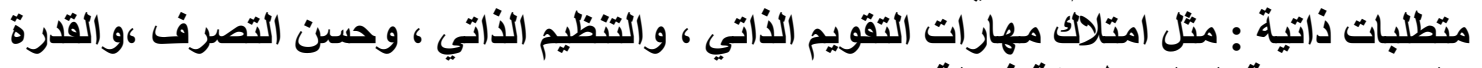

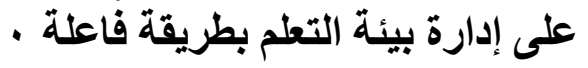

وترى الباحثة أنه إذا كان تعلم المفاهيم يساعد المتعلم على الارتقاء بقدراته العقلية ، كما تعتبر

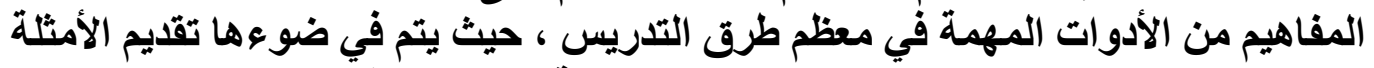

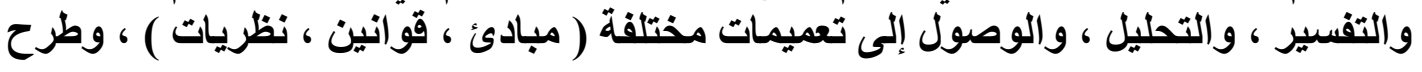


الأسئلة وتصنيف وتنظيم المعلومات وإلمام الطالبة المعلمة بها قد يؤدي إلي ارتفاع الكفاءة الكاءة الذاتية لايها ، وزيادة قوة ثقتها بقدرتها على تنفيذ الأنشطة المطلوبة في ظل متطلبات المات الموقف .

\section{إجراءات البحث:}

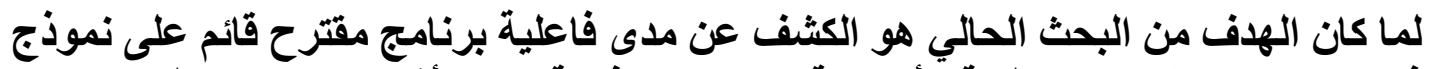

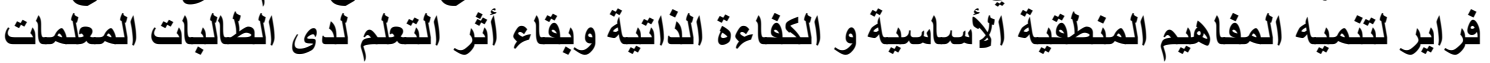
شعبة فلسفة وإجتماع ولتحقيق ذللك قامت الباحثة بالخطوات التئة التالية : اولا: إعداد البرنامج المقترح في المفاهيم المنطقية** : قامت الباحثة بإعداد المخطط العام للبرنامج بإتباع الخطوات التالية : ا-تحديد الأهداف العامة للبرنامج المقترح · r-تحديد محتوى البرنامج المقترح · r-تنظيم محتوى البرنامج المقترح · ع ـتحديد الوسائل والأنشطة التعليمية. هـتحديد طرق واستراتيجيات التدريس .

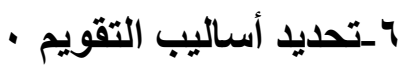

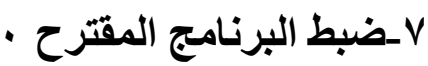
وفيما يلي عرض لهذا الخطوات: ا -تحديد الأهداف العامة للبرنامج المقترح : يهدف البحث الحالي إلي إعداد برنامج مقترح قائم على نموذج فراير لتنميه المفاهيم

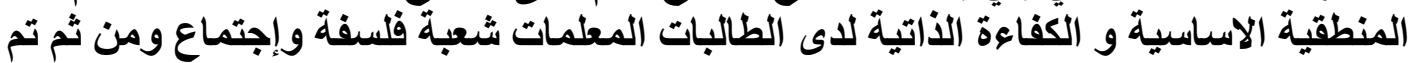

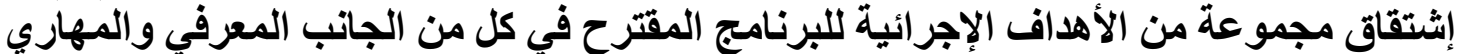

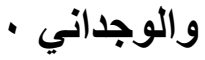

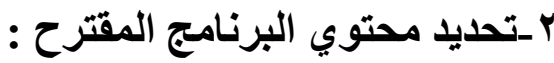

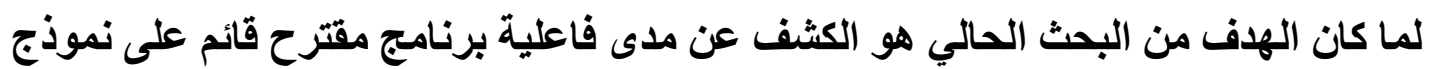
فراير لتنميه المفاهيم المنطقية الأساسية لذلكان تكون البرنامج من مجموعة من المفاهيم المنطقية الأساسية التي يجب على الطالبة المعلمة أن تكون ملمة بها وهذا أستلزم عده خطوات وهى : 
أولاً: إعداد قائمة المفاهيم الأساسية لمادة المنطق للمرحله الثانوية العامة *

أ- الهدف من القائمة : تحديد المفاهيم المنطقية الاساسية لماده المنطق المقررة على طلاب الصف (

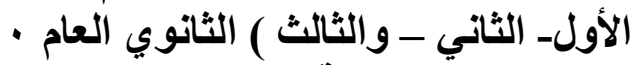

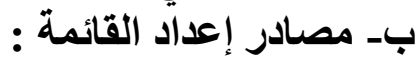
أعلت قائمة المفاهيم المنطقية من خلال الرجوع إلى عده مصادر وهى :

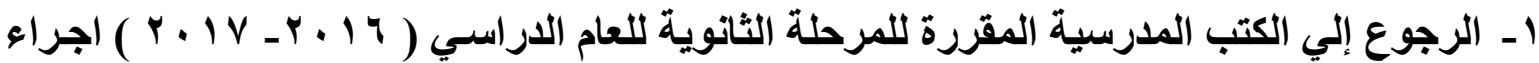

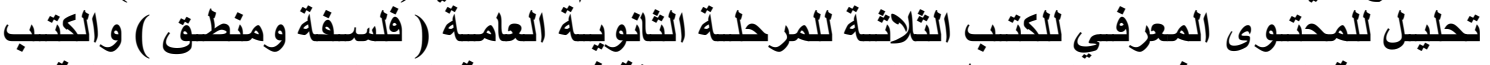

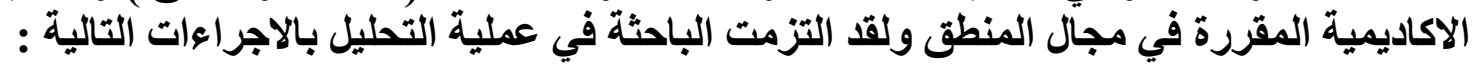

ا ـتحديد فئة التحليل : ويقصد بها في هذا البحث المفاهيم المنطقية الواردة في الكتب الثلاثة والكتب الاكاديمية المقررة في مجال المنطق كفئات يتم في ضونئه الئها عملية التحليل .

r-تحديد وحدة التحليل : حيث اتخذت الباحثة الفقرة وحدة التحليل لانها تتناسب مع طبيعية البحث

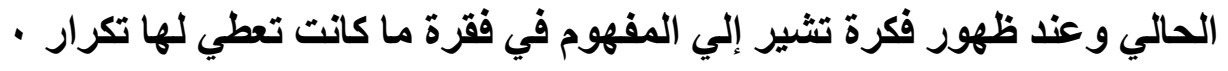
r-راعت الباحثة أثناء قيامها بعملية التحليل اتباع ما يلي : ل قراءة كل موضوع أكثر من مرة قراعة متأنية .

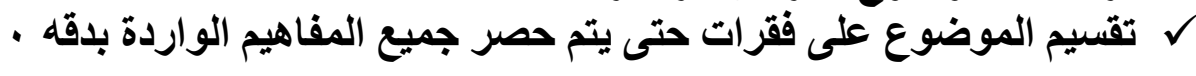
ولكي تتأكد الباحثة من ثبات التحليل قامت بالاتي :-

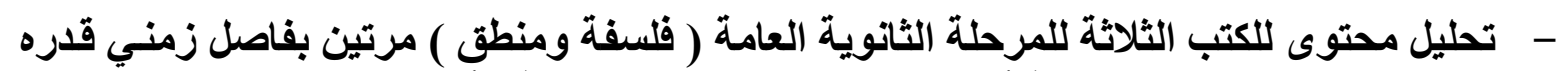

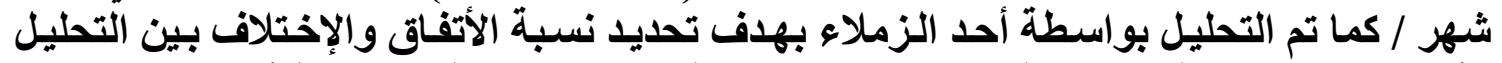

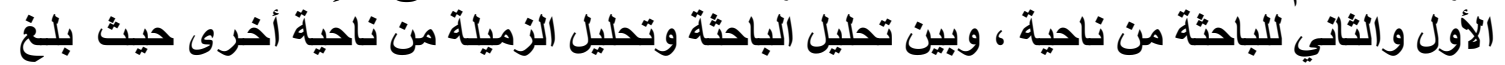

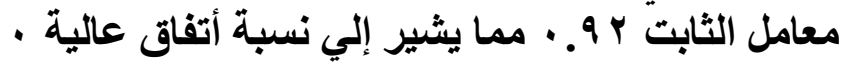

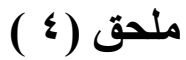

ـالرجوع إلـي بعض الكتب والمراجع الأكاديمية والبحوث التربويـة في مجال المنطق لفحصهـا

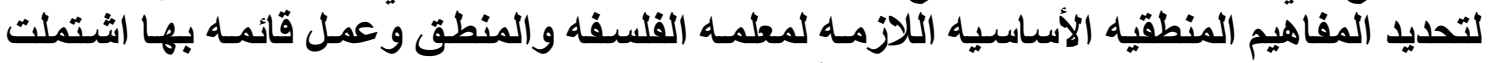

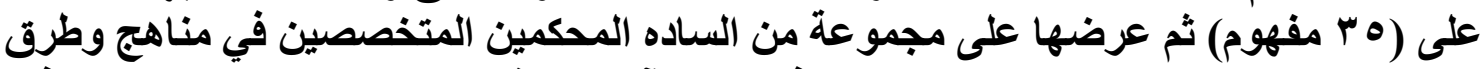

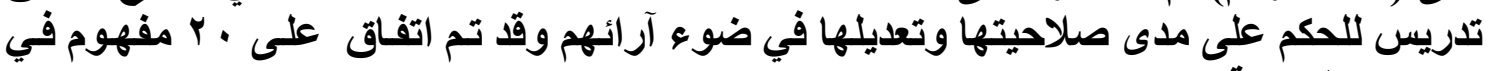
صورتها النهائية . 
تنظيم محتوى البرنامج المقترح :

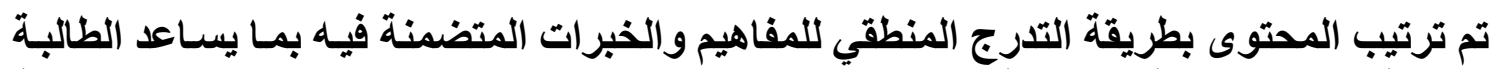

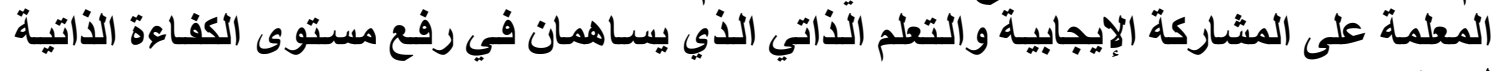

تحديد الوسائل والأنثطة التعليمية:

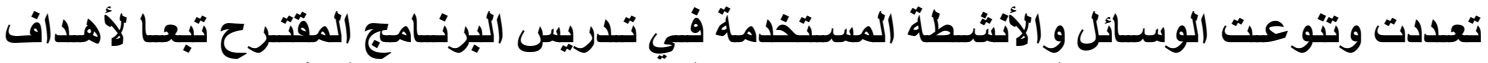

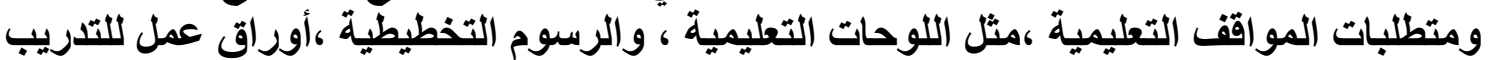

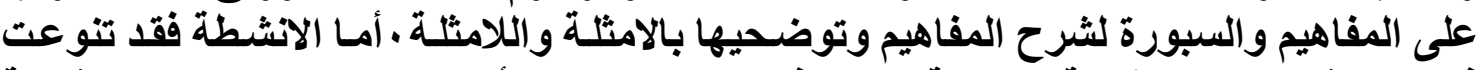

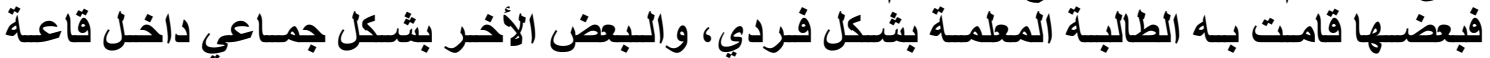

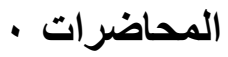

\section{تحديد طرق واستراتيجيات التدريس:}

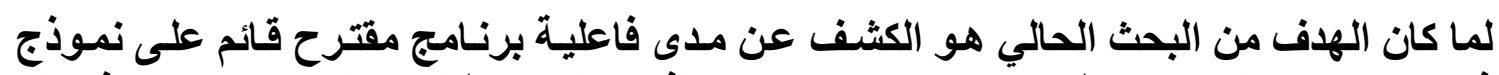

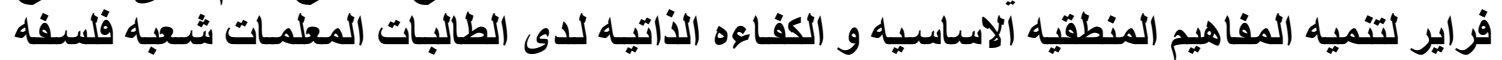

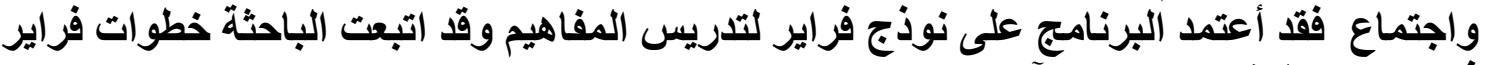
في تلريس المفهوم وهى كالآتي :

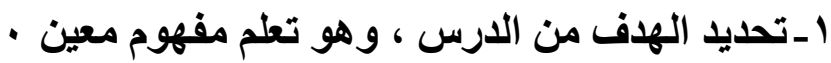

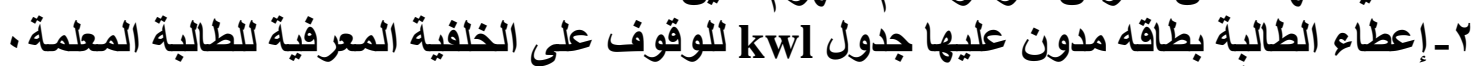

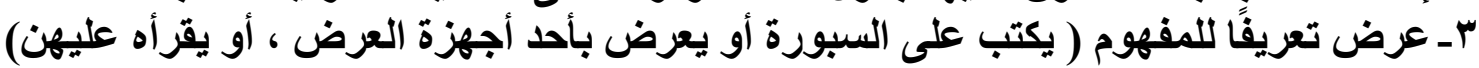

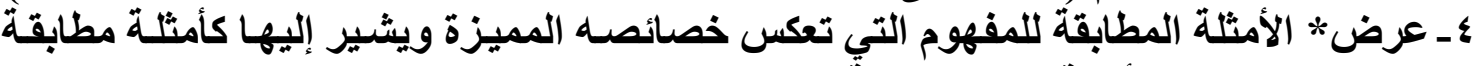

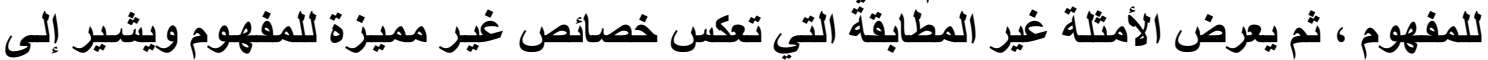

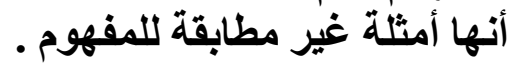
هـ اختبار قدرة الطالبـات المعلمـات على تصنيف أمثلـة جليدة إلى فئـات منتميـة وغير منتميـة

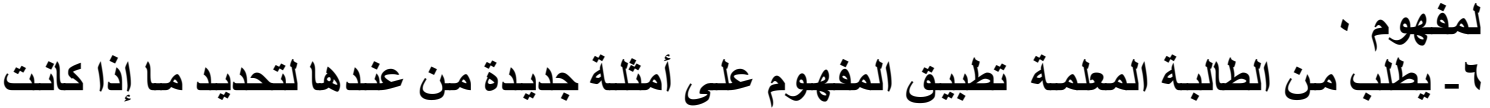

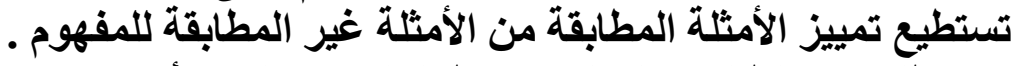

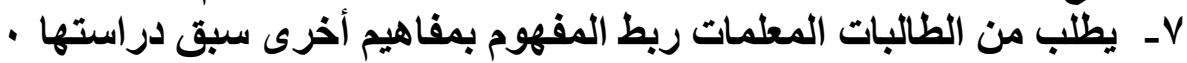

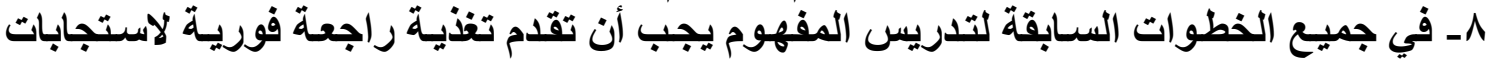
الطالبًات المعلمات ، حتى نتمكن من تعزيز الإجابات الصحيحة وتصويب الخئ الخاطئة .

$$
\text { تحديد أساليب التقويم: }
$$

أستخدمت الباحثة عدة أساليب للتقويم :

1- تقويم قبلي :لتحديد المعارف السابقة في بنية الطالبة المعلمة المعرفية وذلك باستخدام بطاقة $\cdot \mathbf{k w l}$ r- تقويم بنائي يمارس أثناء العرض ، ويشمل أسئلة شفهية ، وتلدريبات تطبيقية على كل مهمة من مهام تلريس المفاهيم المنطقيه . باءل 
r- تقويم نهائي ، ويشمل إختبار لقياس مدى استيعاب الطالبات المعلمات للمفاهيم بعد دراستها

$$
\text { ضبط البرنامج المقترح }
$$

بعد الإتتهاء من إعداد البرنامج المقترح تم عرضه على مجموعة من المحكمين من المتخصصين

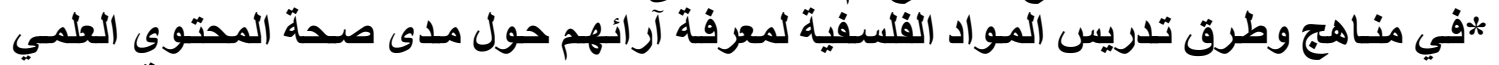

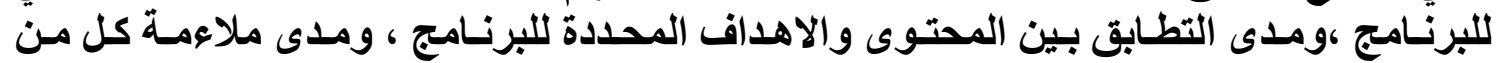

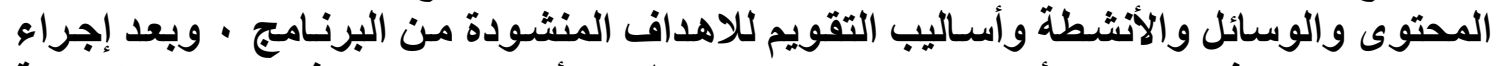

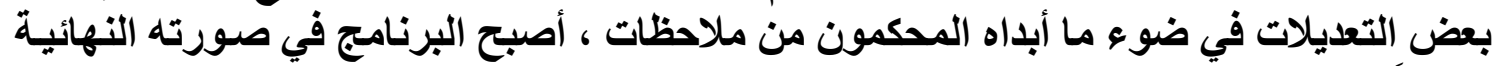

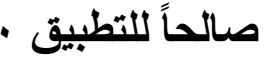

ثانياً: : بناء أدوات البحث

إعداد اختبار المفاهيم المنطقيه:*

أصبح من المتطلبات التي تقتضيها طبيعة الدراسة الحالية قياس تحصيل الطالبات للمفاهيم

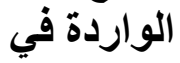

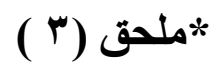

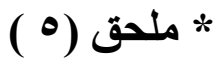

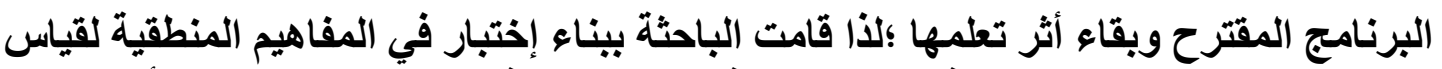

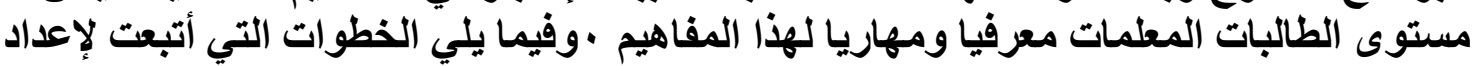

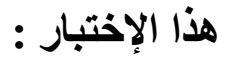

ا -تحديد الهوف من الإختبار :صمم هذا الإختبار بهدف قياس مستوى الطالبه المعلمه ، في

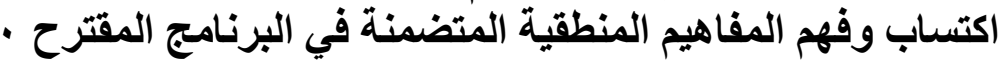

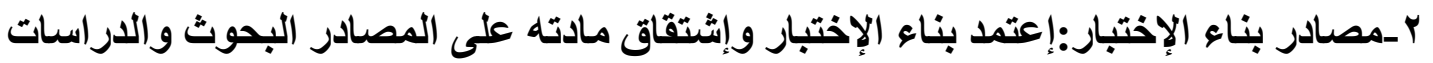

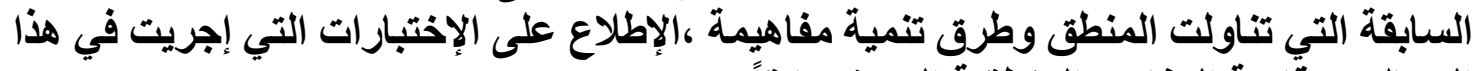

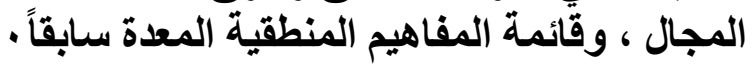

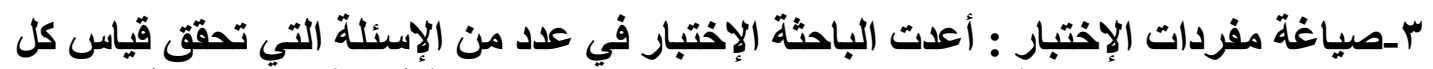

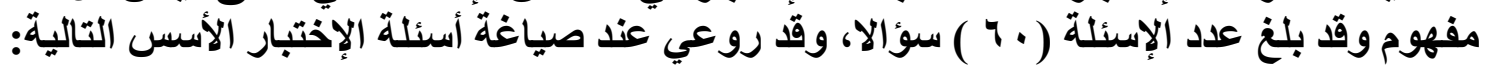

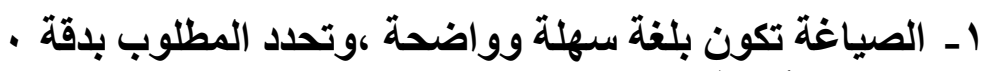

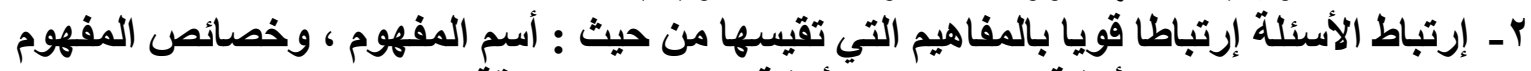

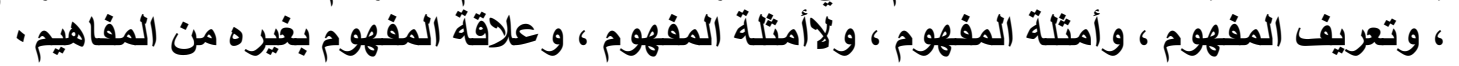
r-حرصت الباحثة على أن تكون أسئلة الاختبار موضوعية وذلك للاعتبارات التالية : 
تمتع هذه الإختبارات بلرجة ثبات عالية ، موضوعية التصحيح ،إمتياز ها بالدقة في تقدير

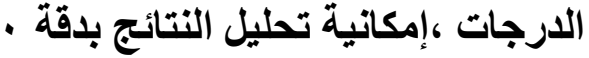

حساب صدق الإختبار :وقد تم عرض الإختبار على مجموعه من السادة المحكمين لإبداء الرأي ألمائ

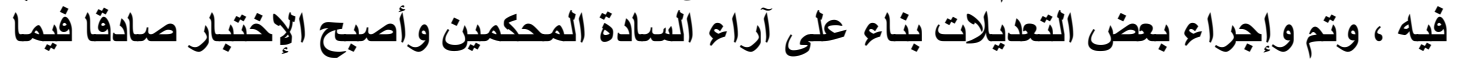
وضع لقياسه

حساب ثبات الاختبار: استخدمت الباحثة طريقة إعادة تطبيق الإختبار ، وبلغ معامل ثبات الاختبار

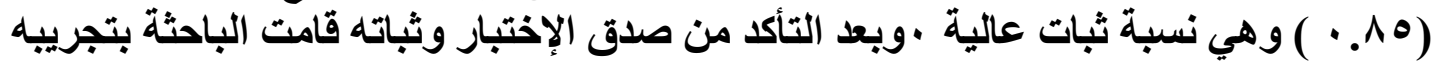

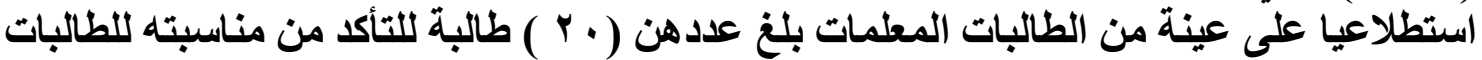

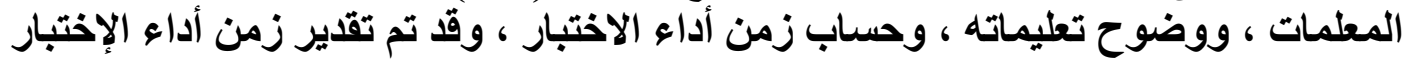

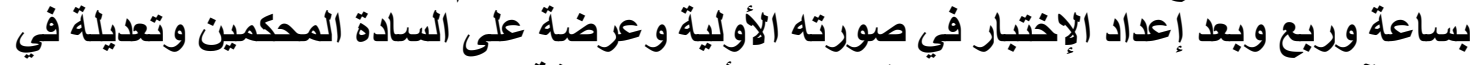

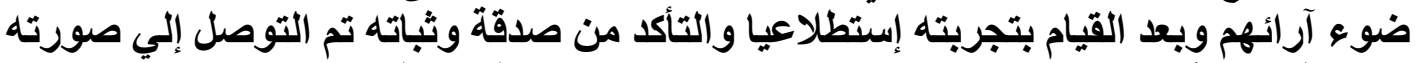

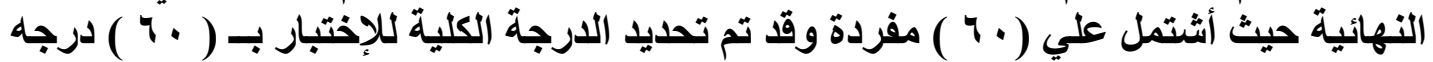

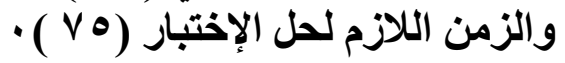

\section{إعداد مقياس الكفاءة الذاتية *}

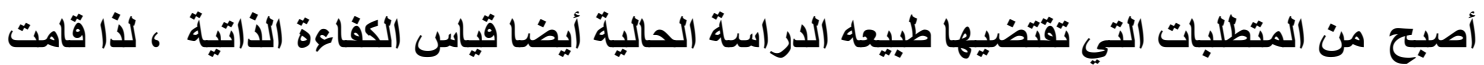

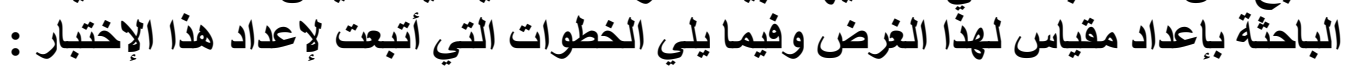
ا ا-تحديد الهذف من المقياس :صمم هذا المقياس بهذف قياس مستوى الطالبه المعلمه ، في

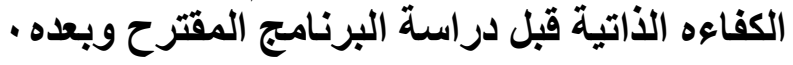

r إمصادر بناء المقياس:أعتمد بناء المقياس وإثتثقاق مادتة على مصادر البحوث والداراسات

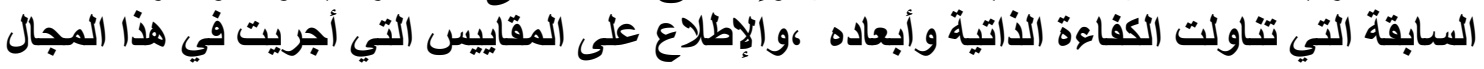

بـاغياغة عبارات المقياس : من خلال الإستفادة من البحوث و الدراسات السابقة في مجال الكفاءة الذاتية صاغت الباحثة عددا من العبارات تتمثل في :-

البعد الأكاديمي: ويقصد به قدرة الطالبة المعلمة على إتمام المهام الاراسية الخاصة بمادة

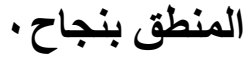
• • بعد الإصرار والمثابره :ويقصد به قدرة الطالبة المطلمة على تنفيذ ما تم تخطيطه مسبقا

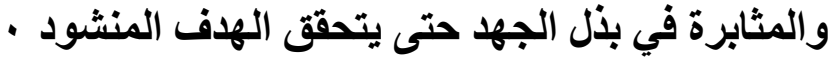

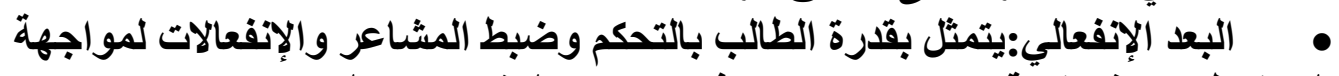
الضغوطات بكفاءة وقد روعي عند صياغه عبارات المقياس ما يلي : r-أن تكون العبارات صالحة لقياس الأبعاد موضع القياس •

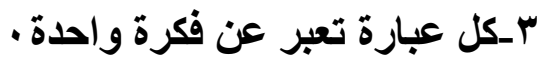




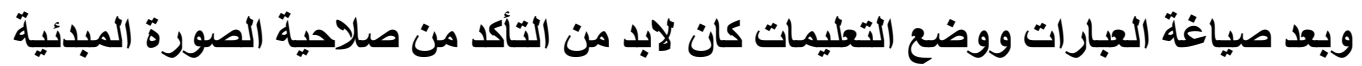

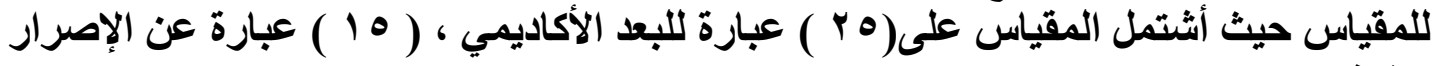
و والمثنابرة

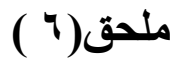

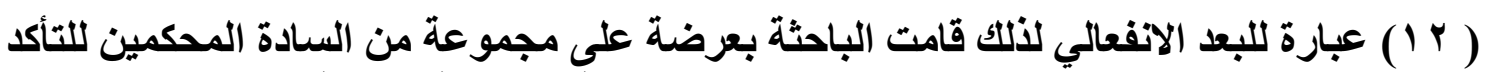

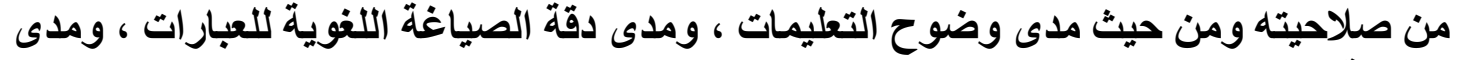

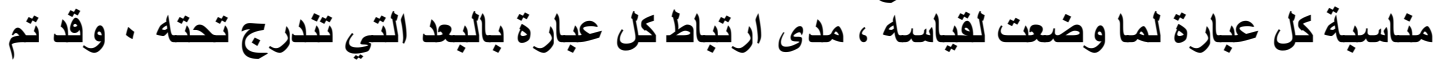

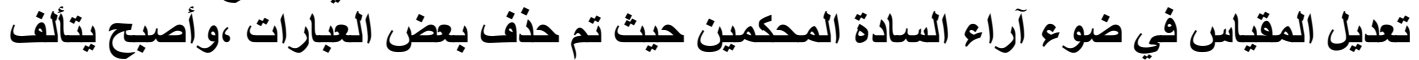

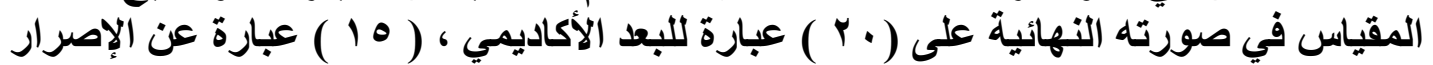

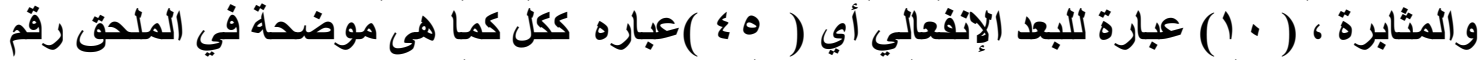

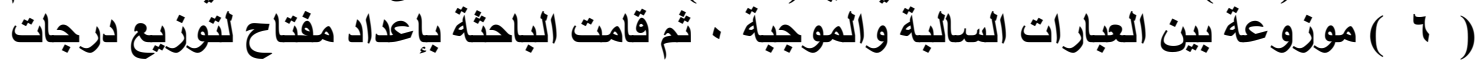
المقياس كما يوضح الجدول التالي ذلك :

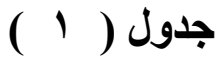

توزيع درجات مقياس الكفاءة الأتية

\begin{tabular}{|c|c|c|c|c|c|}
\hline أبدا & نادرا & أحيانا & غالبا & دائما & العبارة \\
\hline 1 & $r$ & $r$ & $\varepsilon$ & 0 & الموجبة \\
\hline 0 & $\varepsilon$ & $r$ & $Y$ & 1 & السالبة \\
\hline
\end{tabular}

وبذلك تكون أعلي درجة (ه ) درجات في حالة دائما مع العبارة الموجبة وأبدا مع العبارة السالبة

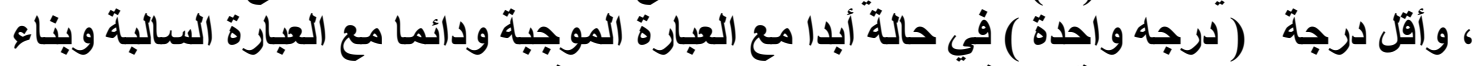

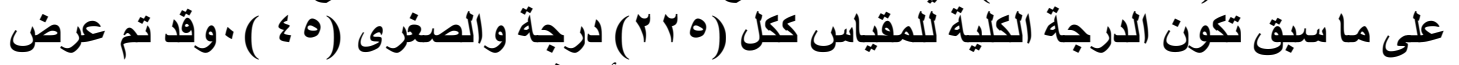

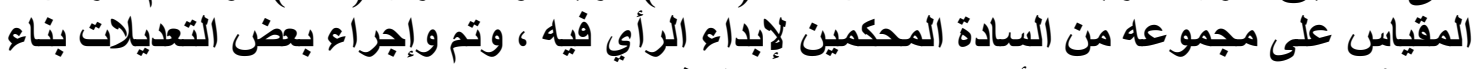

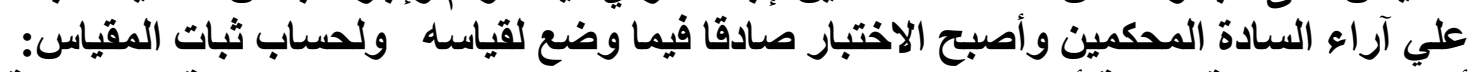

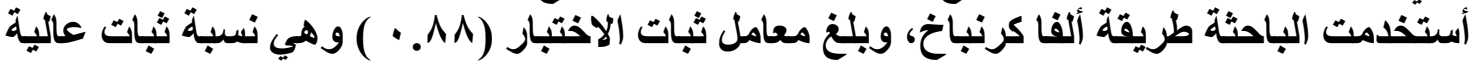

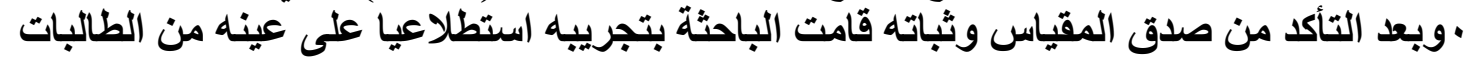

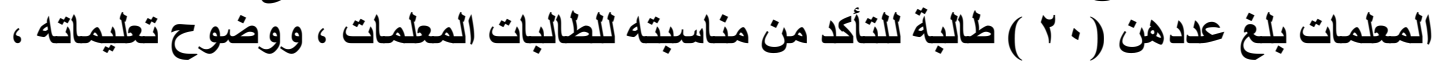

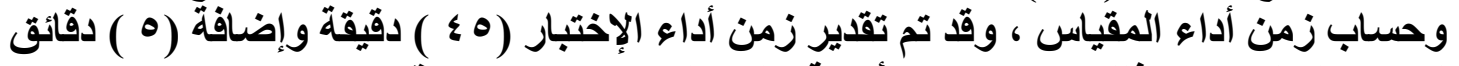

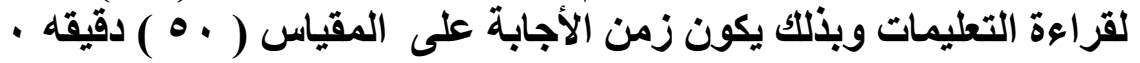

الاجراءات الميدانية

لتطبيق تجربة البحث تم اتباع الخطوات التالية : 


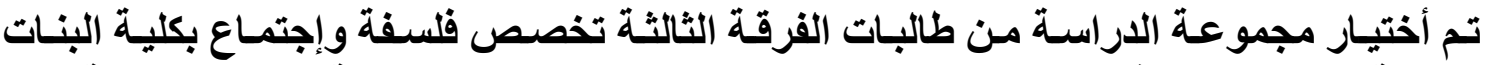

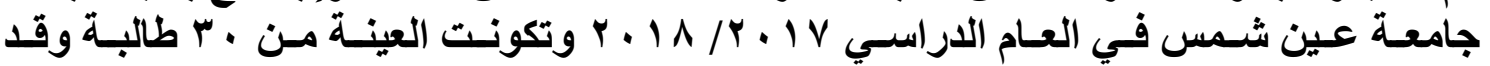

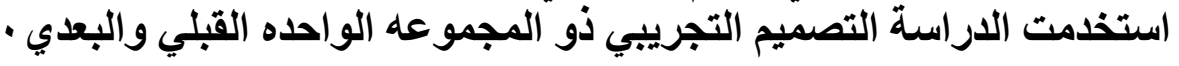

ثانيا- التطبيق القبلي لأدوات القياس : تمثم تطبيق أدوات الدراسة قبل تلدريس البرنامج المقترح

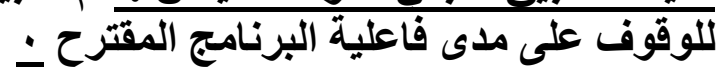

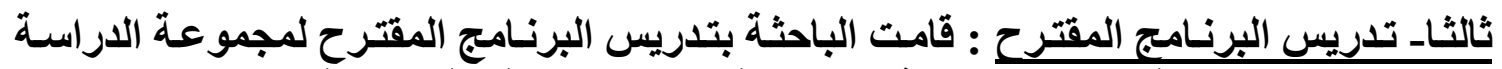

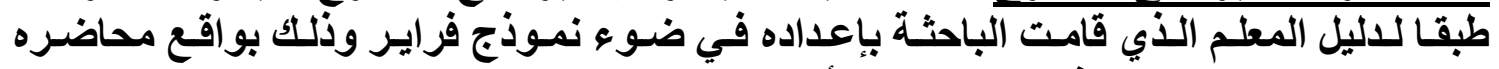

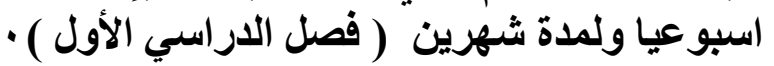

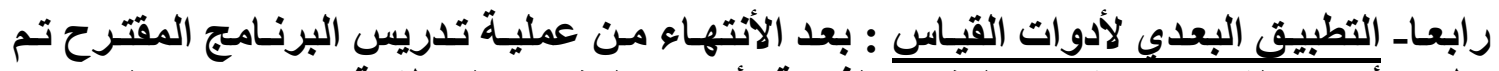

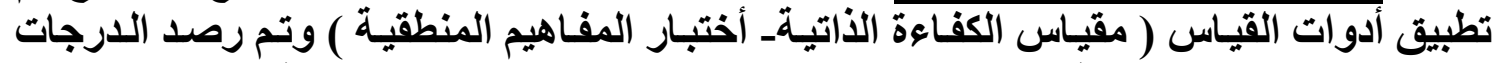

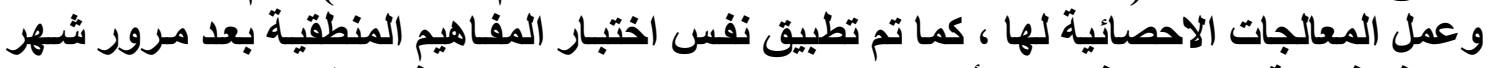

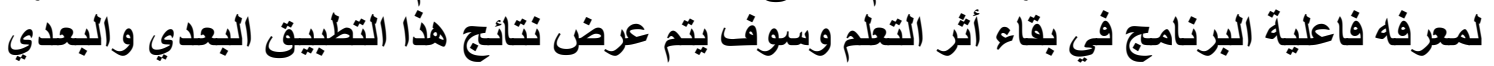

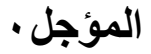

نتائج البحث وتفسيرها

للتحقق من صحة الفروض تم تحليل بعض الجداول الاحصائية للتوصل إلي النتائج التاليه: ل الفرض الاول : يوجد فرق دال إحصائياً بين متوسطى درجات الطالبات المعلمات في الاختبار

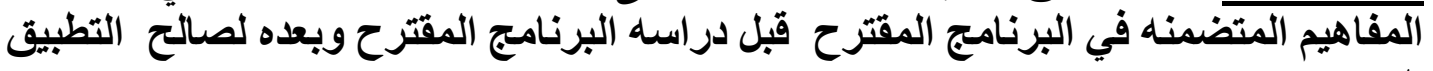
البعدي - (البفاهن

$$
\text { جدول ( r ) }
$$

دلاله الفرق بين متوسطى درجات الطالبات المعلمات في التطبيق القبلي والبعدي لاختبار المفاهيم المنطقيه في في

\begin{tabular}{|c|c|c|c|c|c|c|}
\hline الالالة & قيمة ت & $\varepsilon$ & r & ن & التطبيق & \\
\hline \multirow{2}{*}{ 1الة عند } & & $r, 1$ & $1 \wedge, q Y$ & \multirow[b]{2}{*}{ r. } & قبلي & $\overline{7}=1$ \\
\hline & 11,8 & $1 \%, r$ & $\varepsilon q, r v$ & & بعدي & 星: \\
\hline
\end{tabular}

يتضح من خلال الجدول السابق أرتفاع متوسط درجات الطالبات المعلومـات في التطبيق البعدي

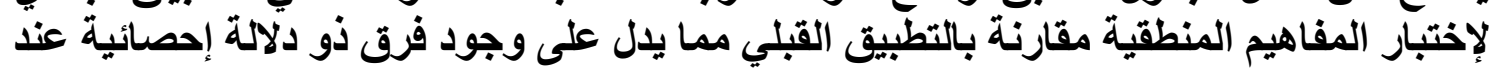




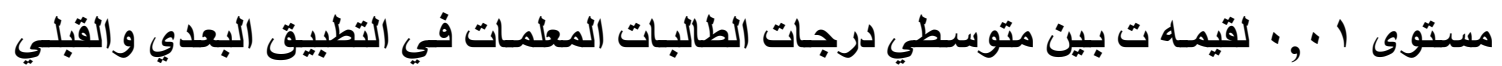
لصالح التطبيق البعدي وهذا يرجع إلي فئلية دالية البرنامج المقترح في تنمية المفاهيم المنطقية .

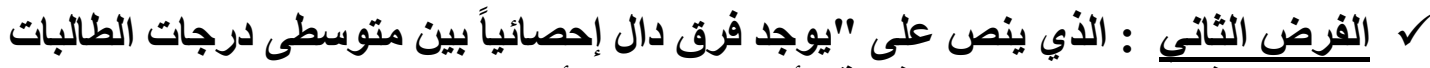

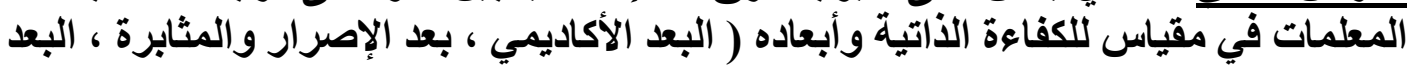

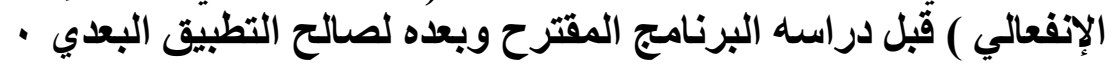

$$
\text { جدول ( r ) }
$$

دلاله الفرق بين متوسطى درجات الطالبات المعلمات في التطبيق القبلي والبعدي في البعد الاكاديمي لوات

\begin{tabular}{|c|c|c|c|c|c|c|}
\hline الدلالة & قيمة ت & $\varepsilon$ & م & $\dot{~}$ & التطبيق & 亏. \\
\hline \multirow{2}{*}{ دالة عند } & \multirow[b]{2}{*}{$M r, \varepsilon$} & $r, 0$ & $1 \leqslant, \varepsilon$ & \multirow[b]{2}{*}{. } & قبلى & \multirow{2}{*}{$\bar{x}$} \\
\hline & & $1 \%$ & $r \checkmark, V V$ & & بعدي & \\
\hline
\end{tabular}

يتضح من خلال الجدول السابق أرتفاع متوسط درجات الطالبات المعلومـات في التطبيق البعدي

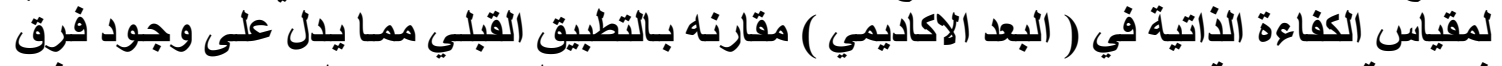

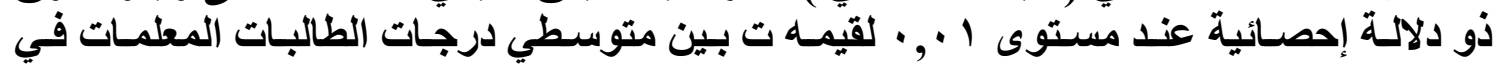

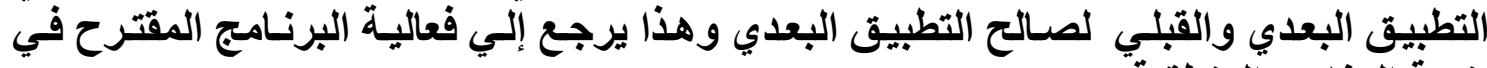
تنمية المفاهيم ألمنطقية.

$$
\text { جدول ( ؛ ؛ ) }
$$

دلاله الفرق بين متوسطى درجات الطالبات المعلمات في التطبيق القبلي والبعدي في بعد الاصرار

\begin{tabular}{|c|c|c|c|c|c|c|}
\hline الدلالة & قيمة ت & $\varepsilon$ & م & ن & التطبيق & \multirow{3}{*}{$\begin{array}{l}\frac{7}{7} \\
\frac{3}{3} \\
\frac{3}{3}\end{array}$} \\
\hline \multirow{2}{*}{ 1الة عند } & & $1, \vee \wedge$ & $\Lambda, \xi$ & \multirow[b]{2}{*}{$r}$. & قبلي & \\
\hline & $r v, q$ & 1,0 & $1 \wedge, r$ & & بعدي & \\
\hline
\end{tabular}
والمثابرة

يتضح من خلال الجدول السابق أرتفاع متوسط درجات الطالبات المعلومـات في التطبيق البعدي

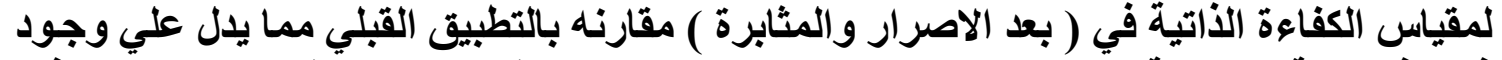

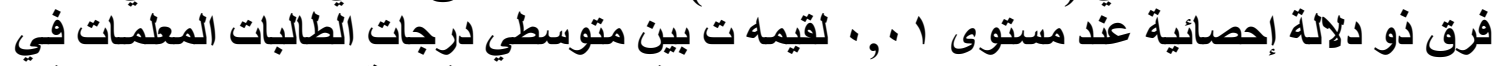

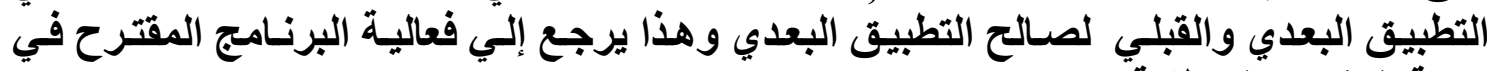
تنمية المفاهيم المنطقية. 
دلاله الفرق بين متوسطى درجات الطالبات المعلمات في التطبيق القبلي والبعدي في البعد الانفعالي

\begin{tabular}{|c|c|c|c|c|c|c|}
\hline الالالة & قيمة ت & $\varepsilon$ & p & ن & التطبيق & $\bar{y}$. \\
\hline \multirow{2}{*}{ 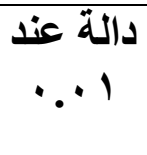 } & & $\cdot, \wedge$. & $r, 0$ & \multirow[b]{2}{*}{ r. } & قبلي & $\overline{7}$ \\
\hline & YYY & $\cdot 90$ & $v, v \cdot$ & & بعدي & 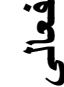 \\
\hline
\end{tabular}

يتضح من خلال الجدول السابق أرتفاع متوسط درجات الطالبات المعلومـات في التطبيق البعدي

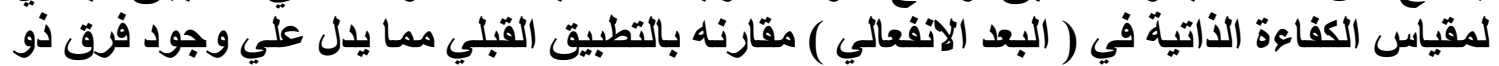

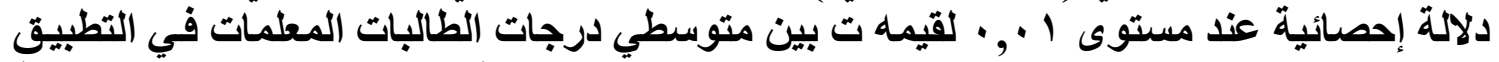

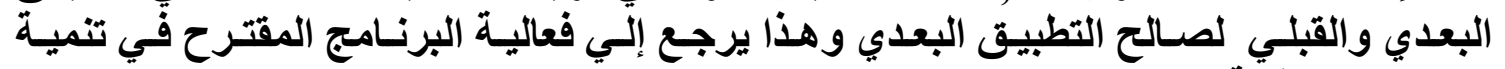

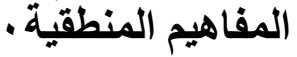

$$
\text { جدول (1 ) }
$$

دلاله الفرق بين متوسطى درجات الطالبات المعلمات في التطبيق القبلي والبعدي في مقياس

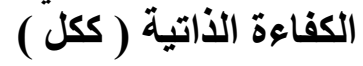

\begin{tabular}{|c|c|c|c|c|c|c|}
\hline الدلاكة & قيمة ت & $\varepsilon$ & r & ن & التطبيق & 象 \\
\hline \multirow{2}{*}{ ا دالة عند } & \multirow[b]{2}{*}{$\leqslant \wedge, 7$} & $r . \leqslant 0$ & ro, 1 & \multirow[b]{2}{*}{$r}$. & قبلي & \multirow{2}{*}{$\bar{y}$} \\
\hline & & $r, V_{1}$ & $01, \mu$. & & بعدي & \\
\hline
\end{tabular}

يتضح من خلال الجدول السابق ارتفاع متوسط درجات الطالبات المعلومسات في التطبيق البعدي

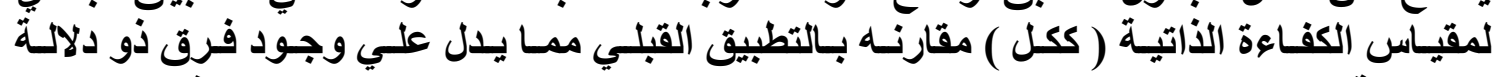

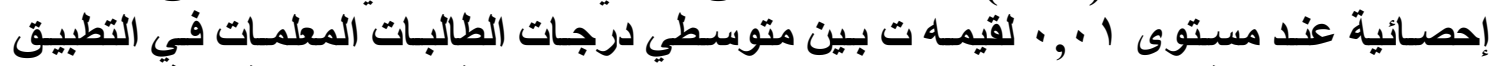

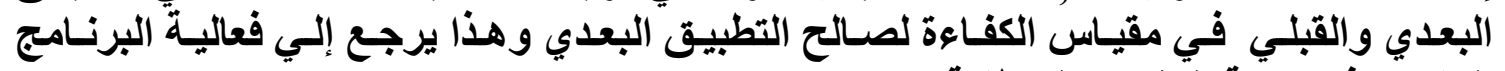
المقترح في تنمية المفاهيم المنطقية.

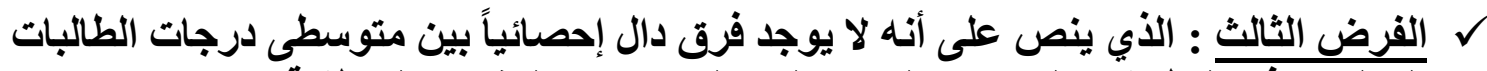

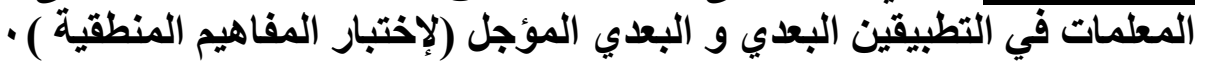




$$
\text { (V ) جدول (v) }
$$

دلاله الفرق بين متوسطى درجات الطالبات المعلمات في التطبيق ( البعدي- والبعدي المؤجل ) لإختبار المفاهيم المنطقيه

\begin{tabular}{|c|c|c|c|c|c|c|}
\hline الدلالة & قيمة ت & $\varepsilon$ & ? & $\dot{0}$ & التطبيق & \\
\hline & & ${ }^{\prime r}, r$ & $\varepsilon 7, r v$ & & البعدي & $\overline{7}$ \\
\hline غير دالة & $\cdot 0$ & 11,7 & \& \&, & $r$. & المؤجلي & 最 \\
\hline
\end{tabular}

يتضح من خلال الجدول السابق عدم وجود فرق ذو دلالة إحصائية عند مستوى 1 •, , لقيمـه

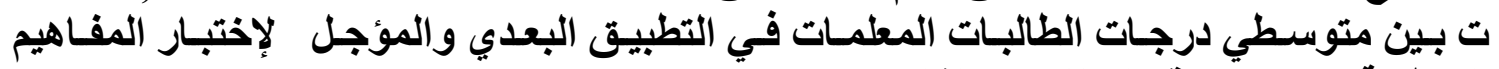
المنطقية ، مما يعني قبول الفرض الثالث

مناقشثة النتائج وتفسير ها

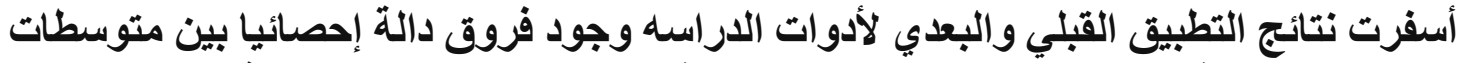

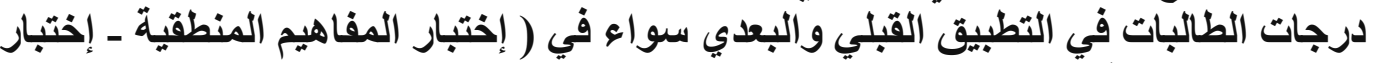

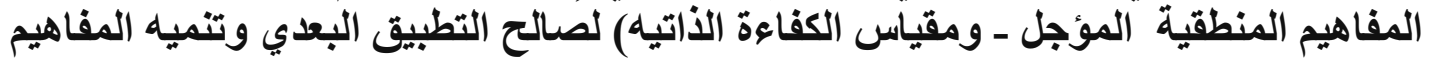

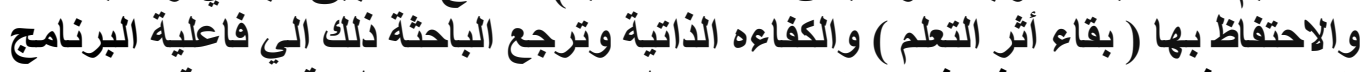

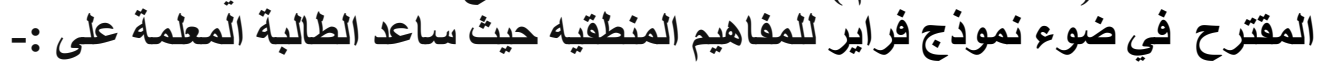

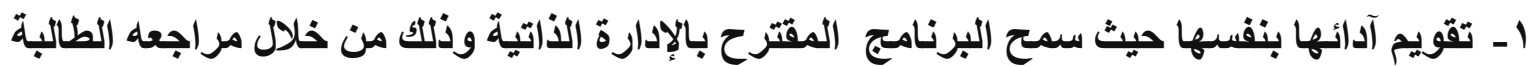

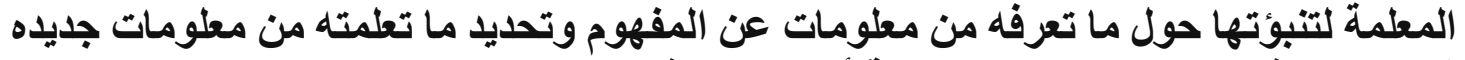

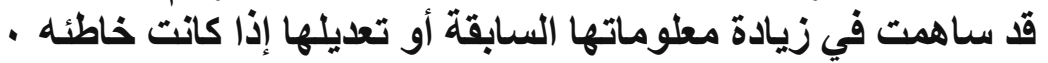

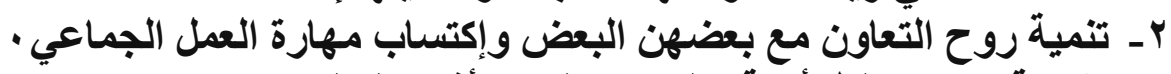

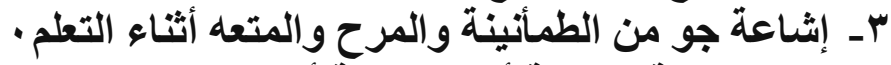

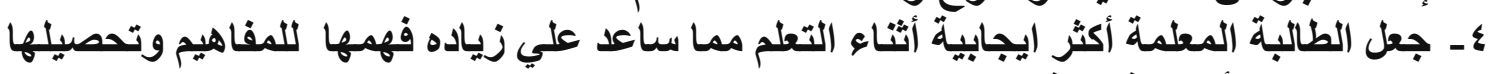

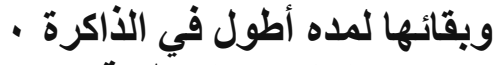

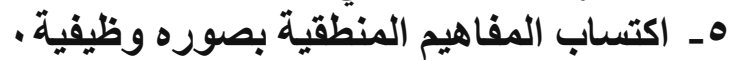

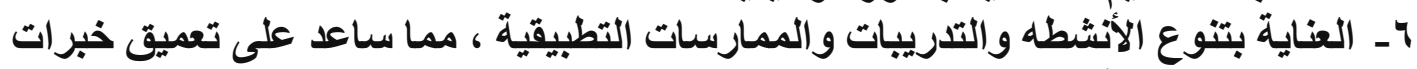

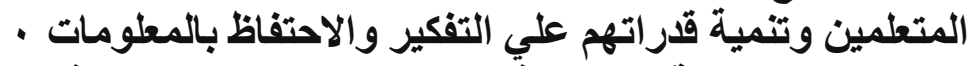

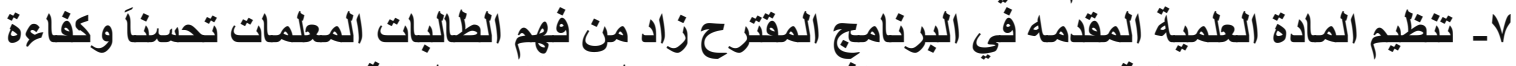

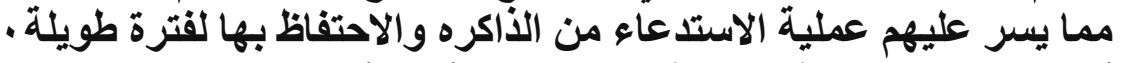

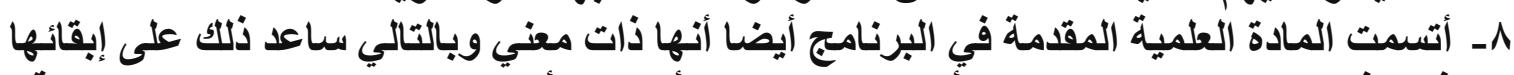

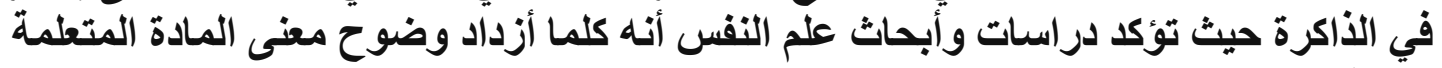

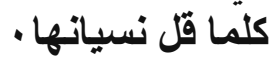
و هكذا تتثق نتائج هذه الدراسة مع نتائج بعض الدراسات العربية والاجنبية مثل:

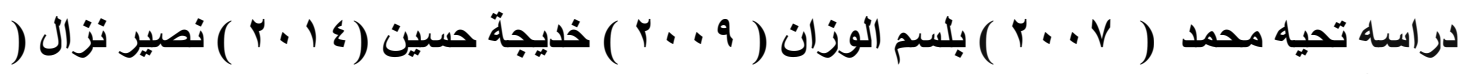


Nahampun, E.E., \& Sibarani, B. ((2014) والتي أكدوا جميعا علي أن استخدام

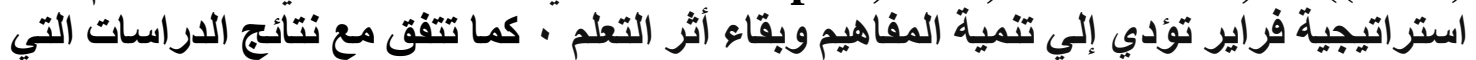

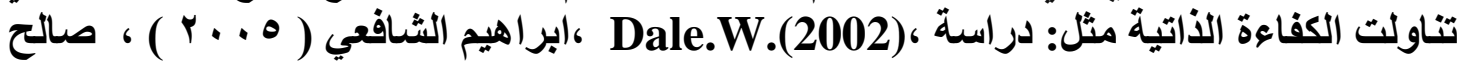

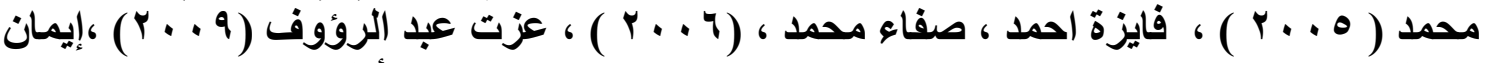

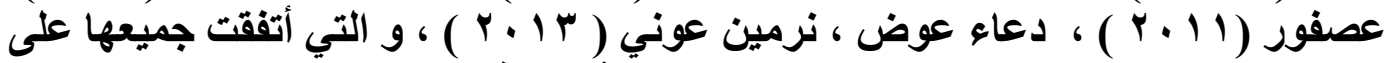

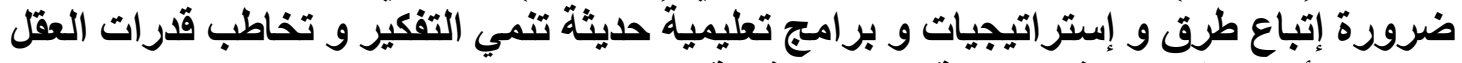
و تهتم بتأثير الاقران و ذلتك التنمية الكفاءة الذاتية.

\section{توصيات البحث}

في ضوء نتائج البحث يمكن تقايم مجموعة من التوصيات كما يلي :

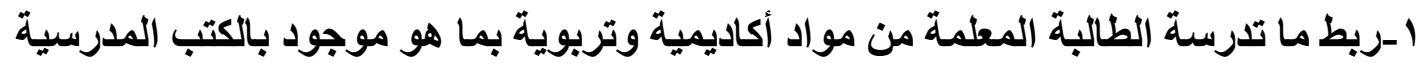

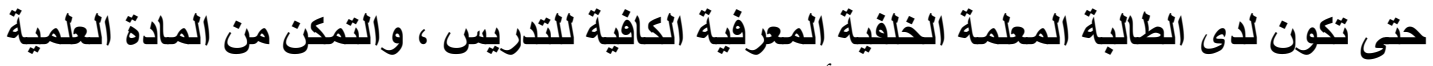

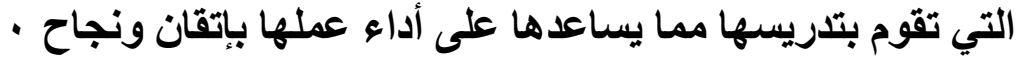

r ب-تدريب الطالبة المعلمة للمواد الفلسفية على النماذج التدريسية التي أثبتت الابحاث و الاراسات

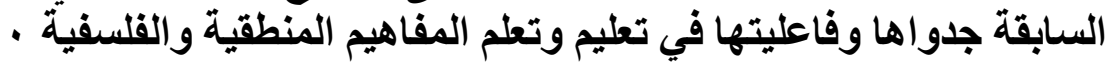

بـتـتمين برامج ودورات إعداد معلمي القلسفة والمنطق بتعليم المفاهيم الاساسيه واستراتيجيات وأساليب تدريسها وأسس تقويمها

مقترحات البحث

في ضوء نتائج البحث الحالي يمكن اقتراح اجراء البحوث الآتية: ا-برنامج مقترح لمعلمى الفلسفة والمنطق لتنمية الوعي بالمفاهيم المنطقية واثره على الاداء

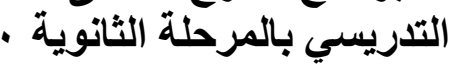

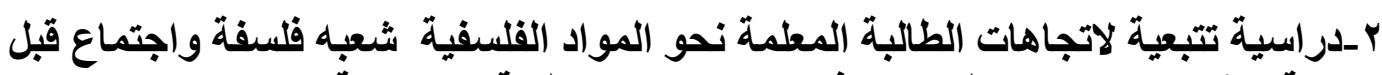

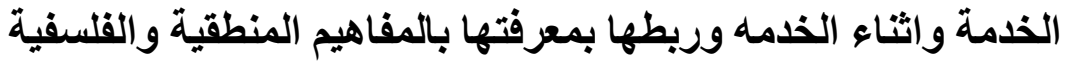

بـدراسة العلاقة بين مستوى تمكن معلم الفلسفة والمنطق والمعلمات من المفاهيم المنطقية

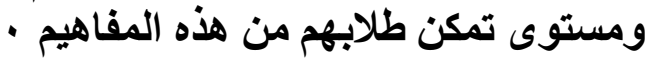




\section{مراجع البحث}

اولا- المراجع العربية :

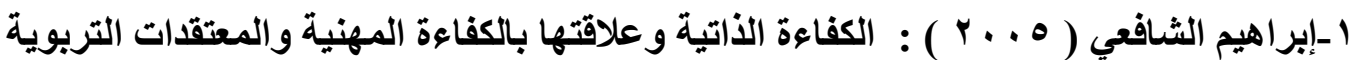
والضفوط النفسية لاى المعلمين وطلاب كلية المعلمين ، بالمملكة العربية السعودية ، المجلة التربوية ،

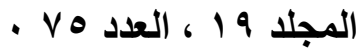

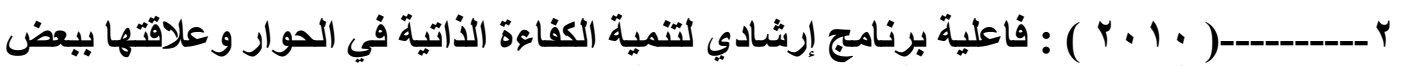

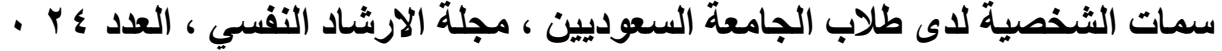

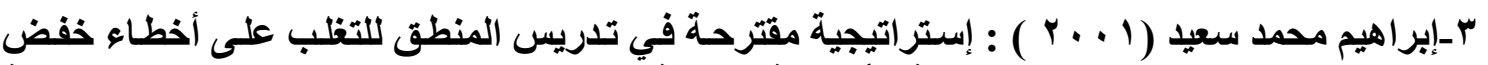

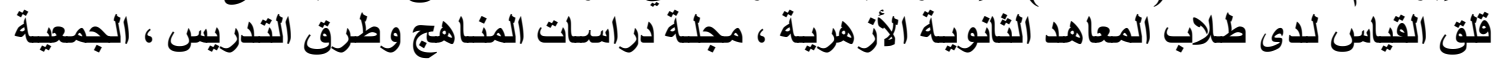

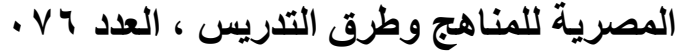

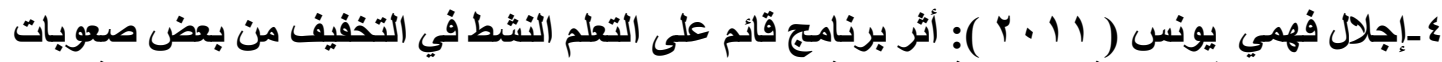

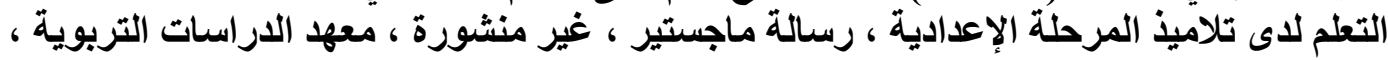

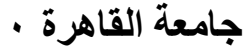

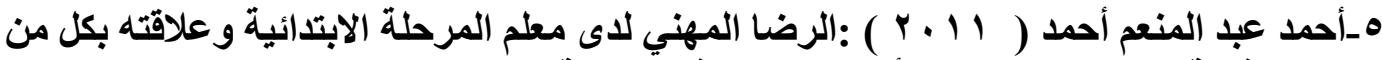

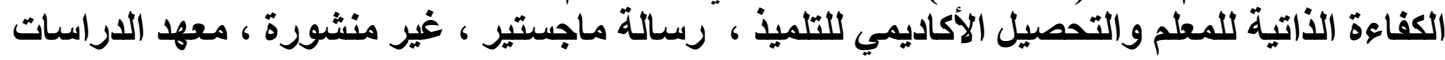

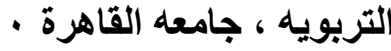

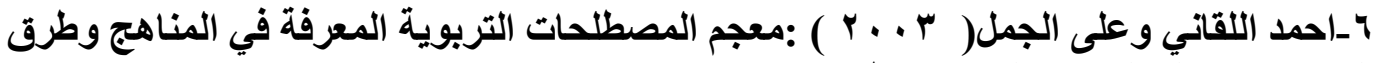

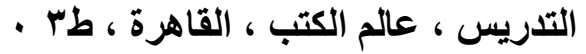

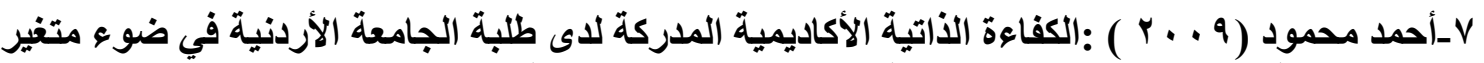

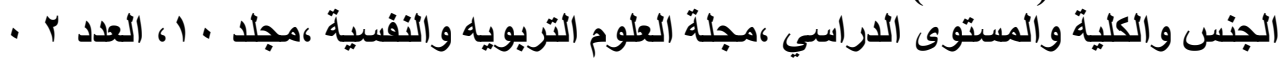

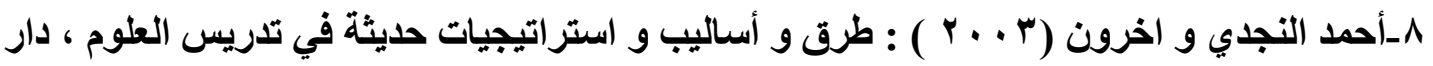

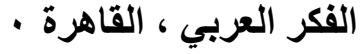

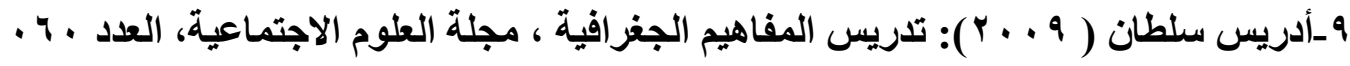

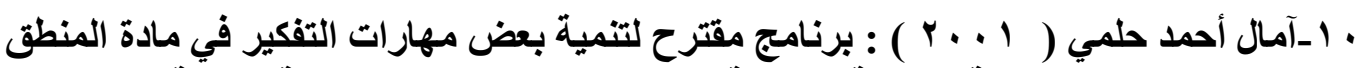
باستخدام الكمبيوتر للمرحلة الثانوية ، رسالة ماجستير ، غير منشورة ، كلية التربية بينها ، جامعه مئه · الزقازيق

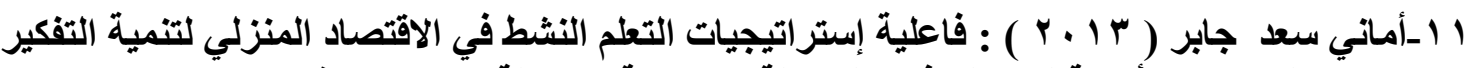

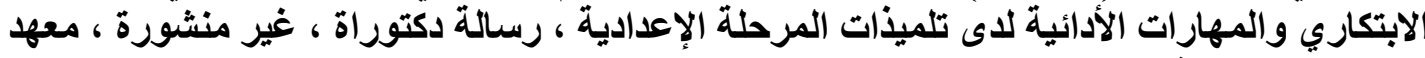

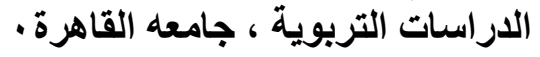

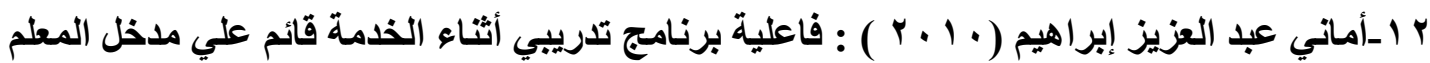

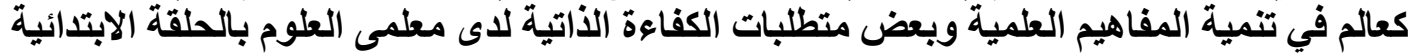

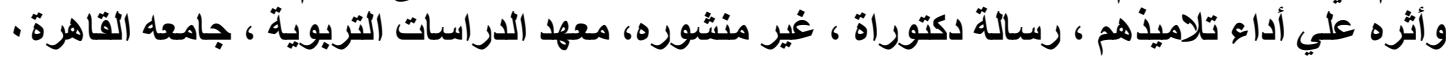




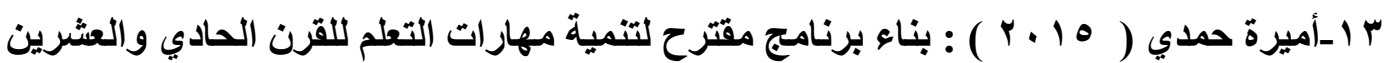

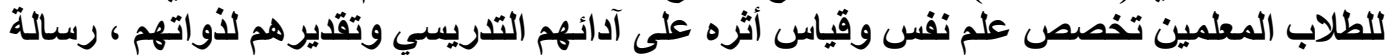

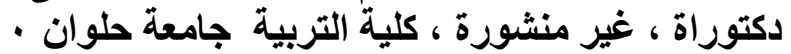

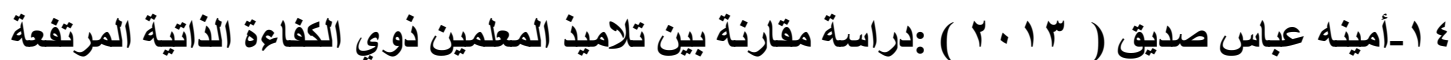

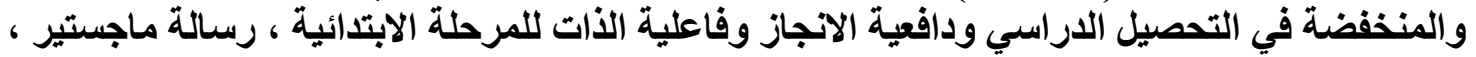
غير منشورة ، معهد الدراسات التربوية ، جامعة القاهرة .

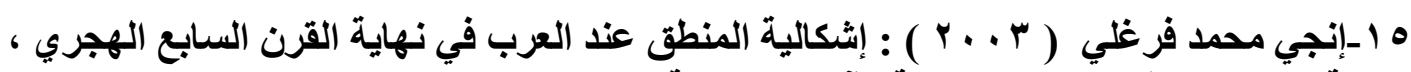

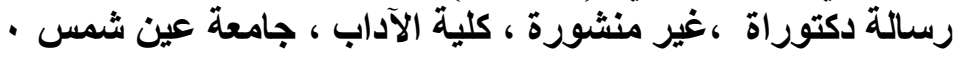

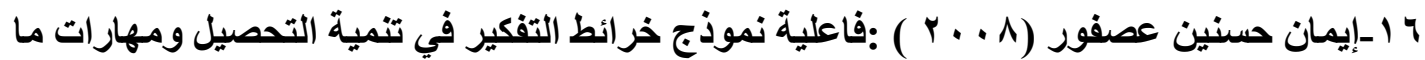

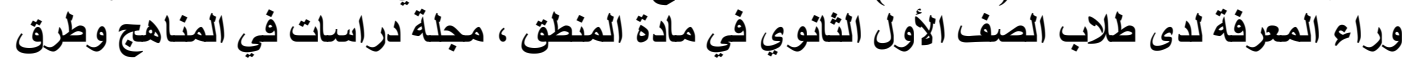

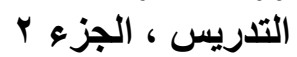

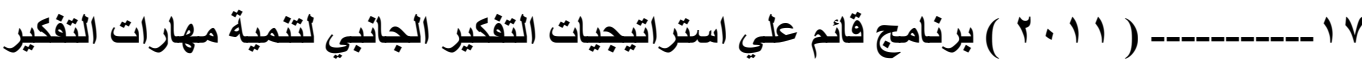

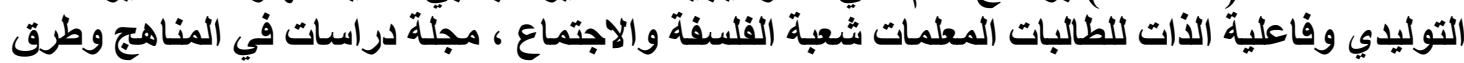

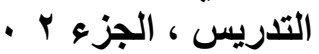

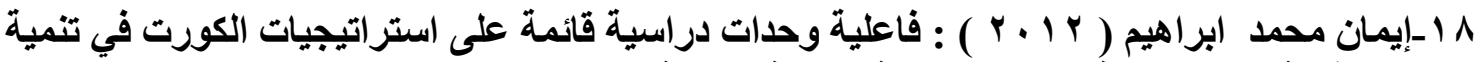

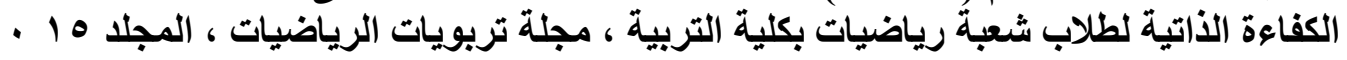

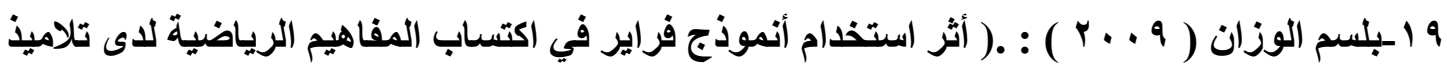

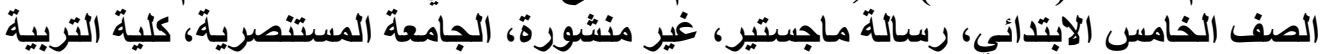

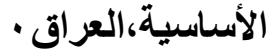

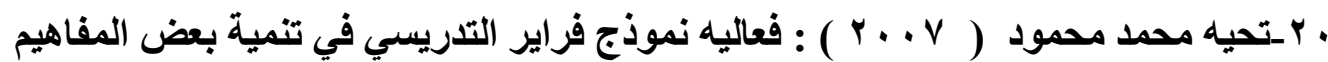

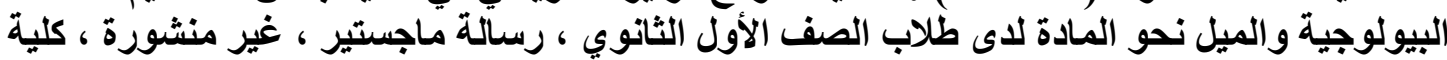
التربية ، جامعه حلوان

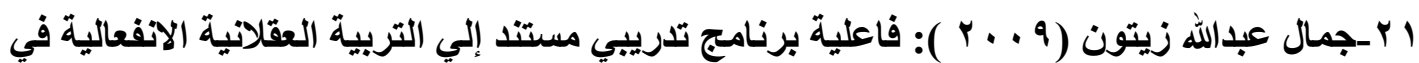

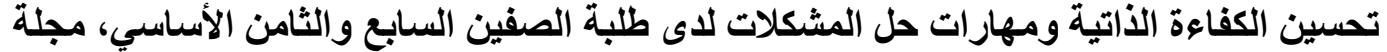

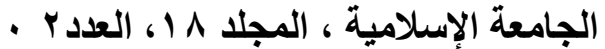

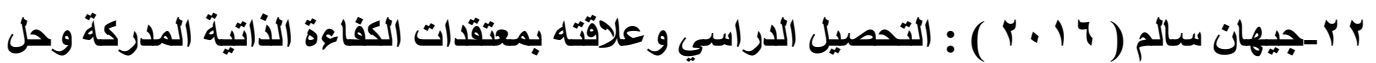

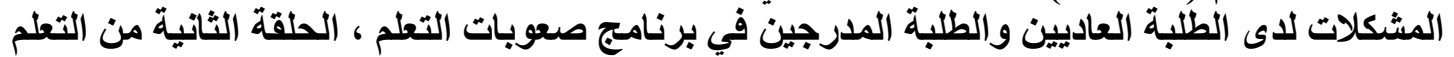

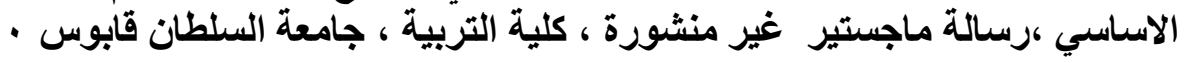

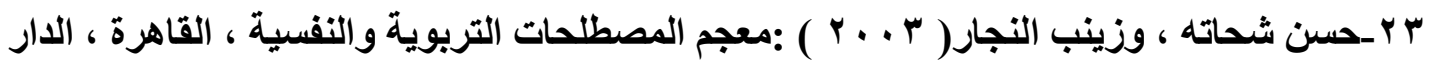

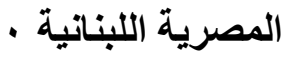

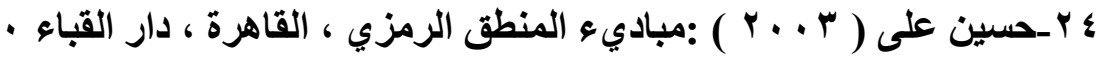

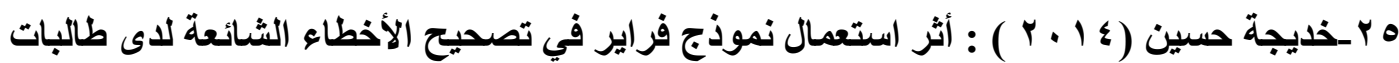

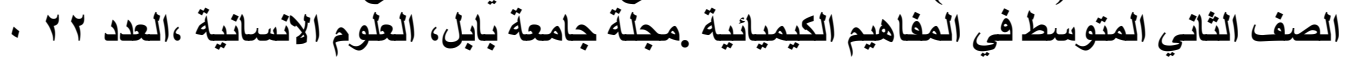




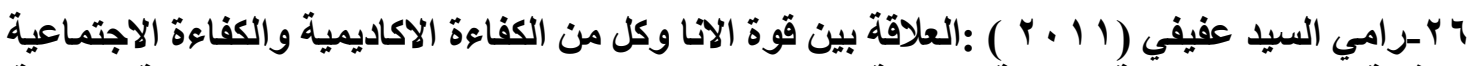

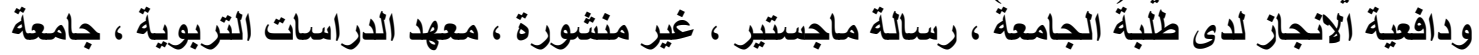

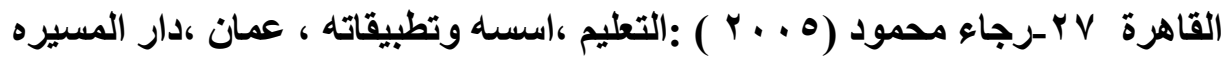

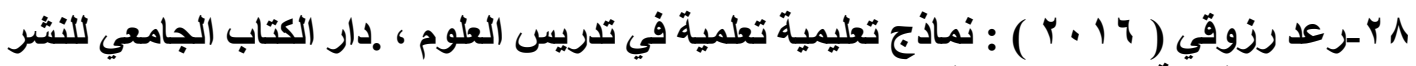

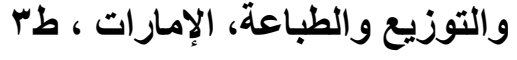

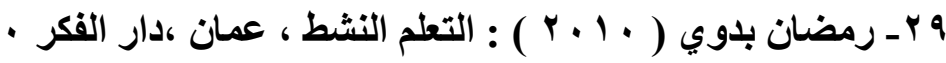

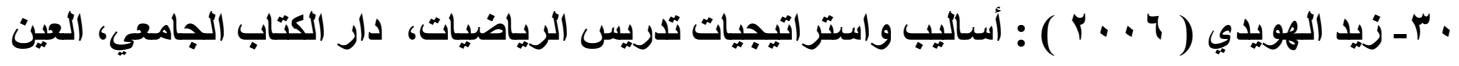

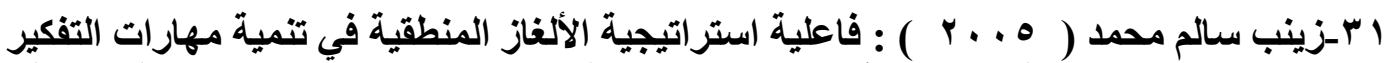

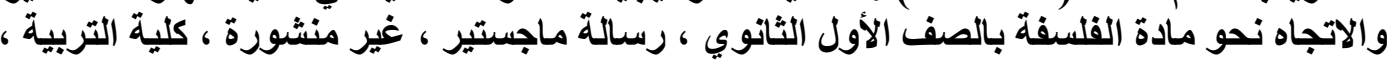
جامعة حلوان

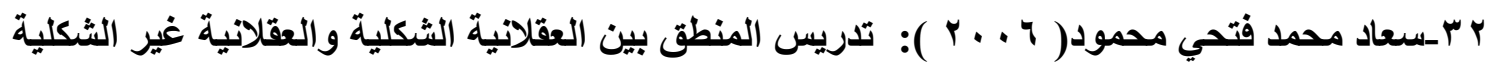

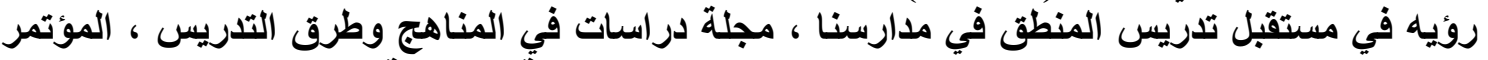

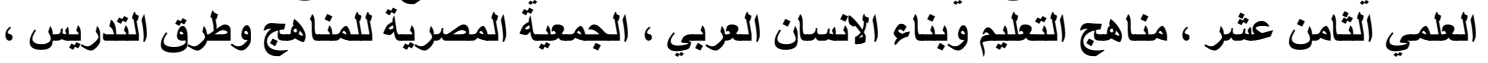

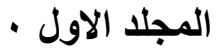

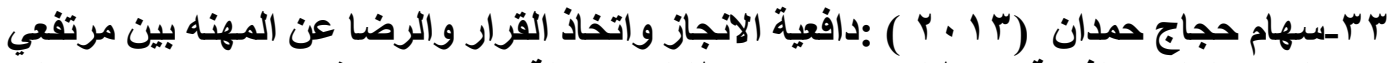

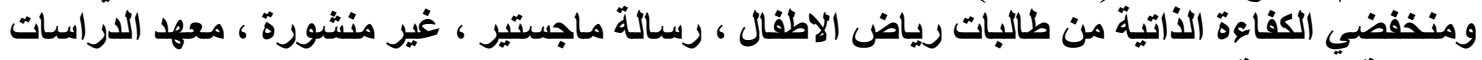

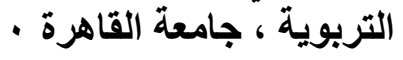

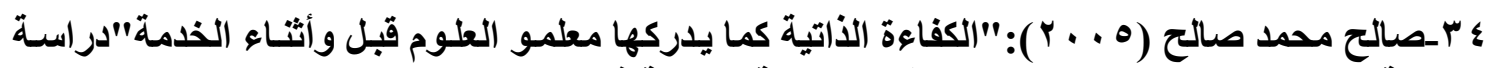

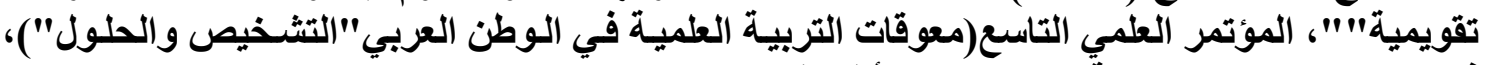

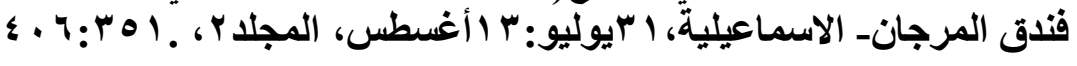

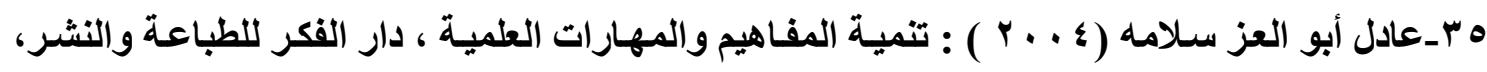
عمان

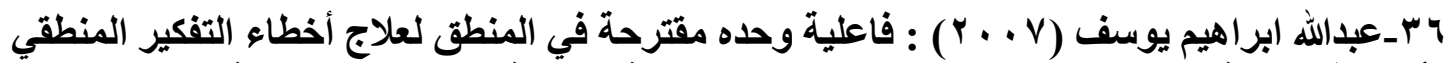

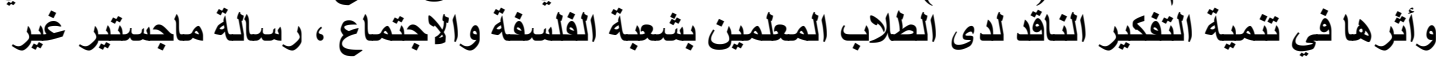

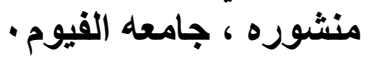

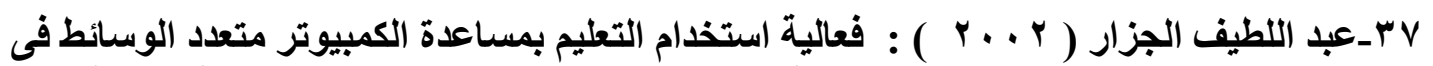

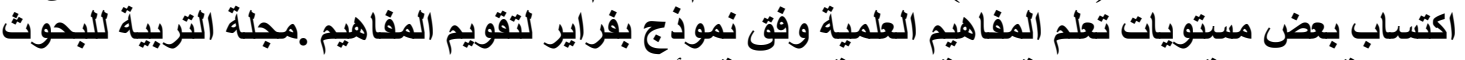

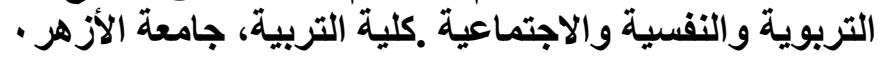

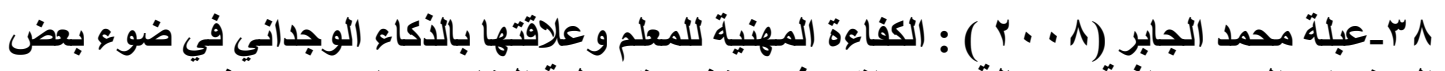

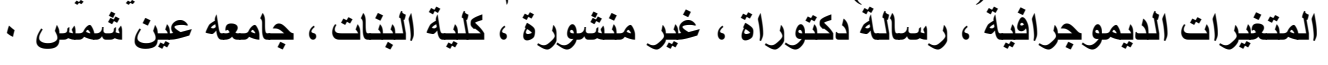

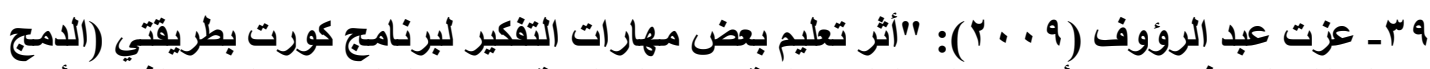

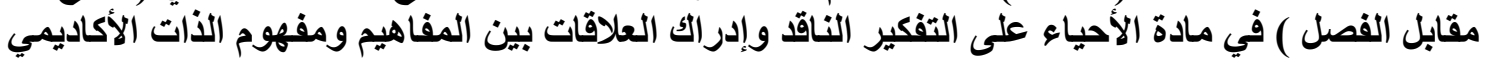


لاى طلاب الصف الأول الثانوي"، المؤتمر العلمي الحادي والعثرون(تطوير المناهج الدراسية بين

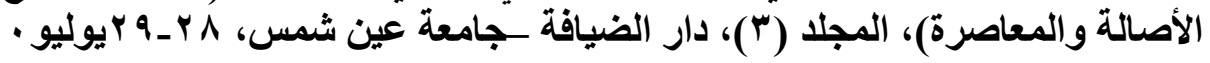

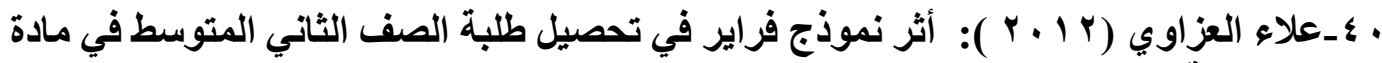

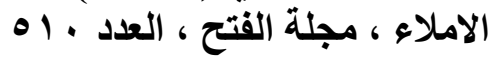

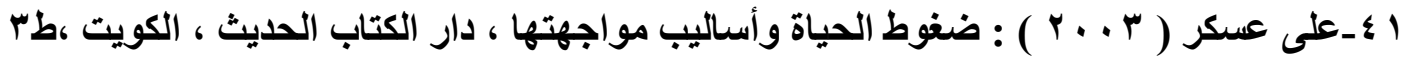

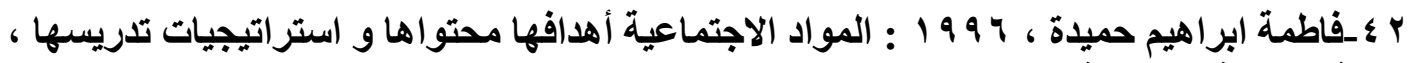

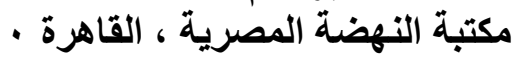

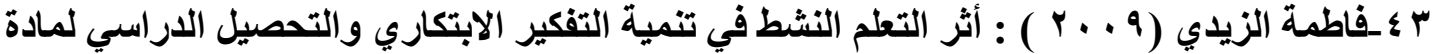

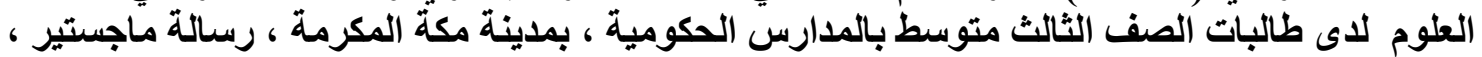

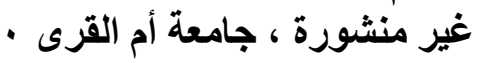

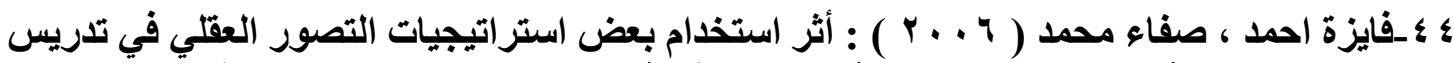

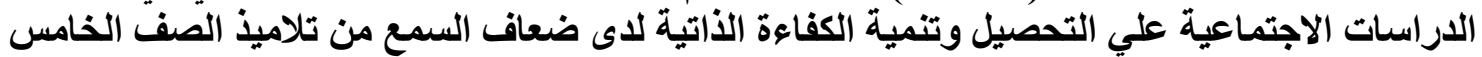

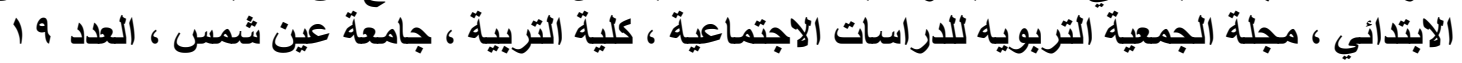

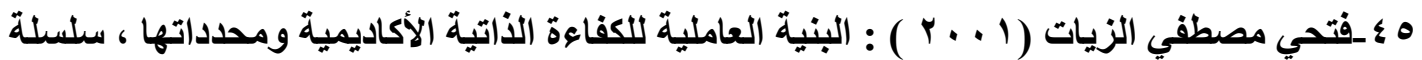

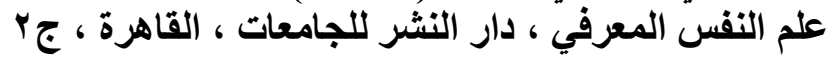

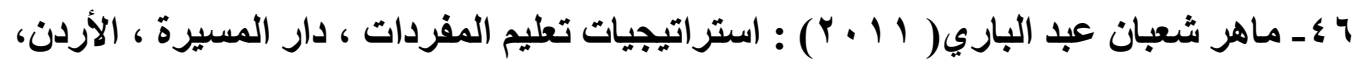
عمان، مان

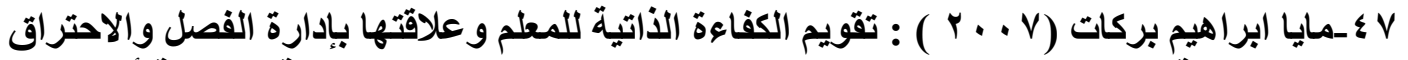

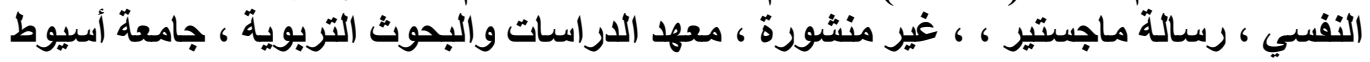

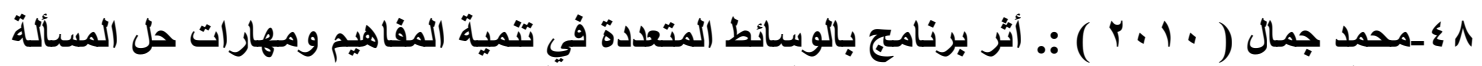

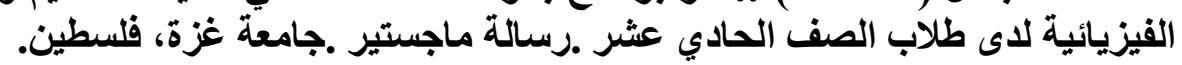

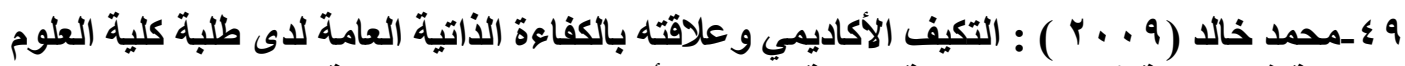

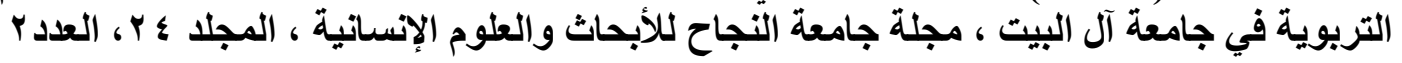

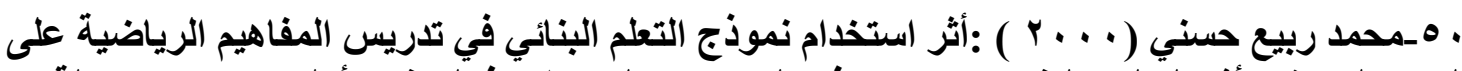

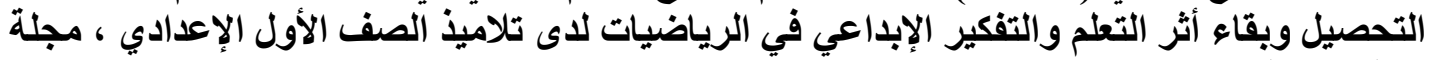

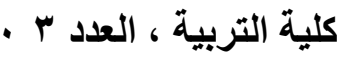

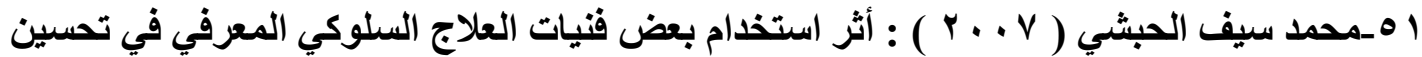

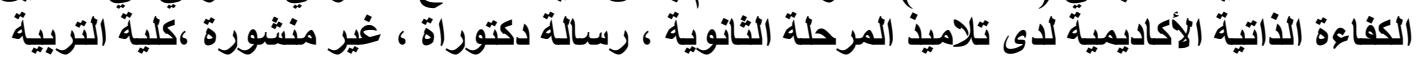
جامعة المنصورة

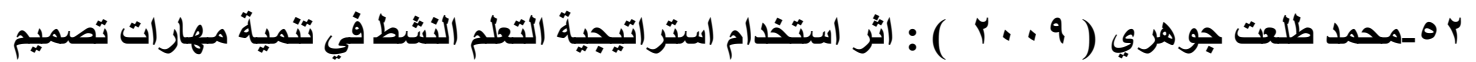

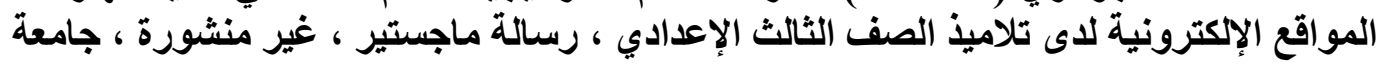




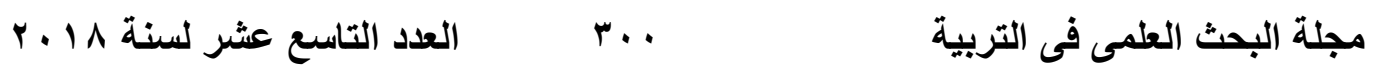

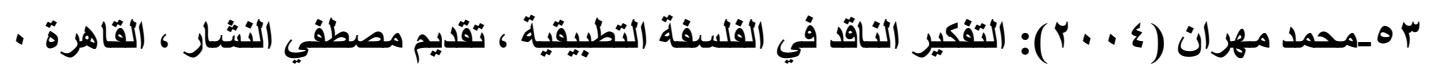

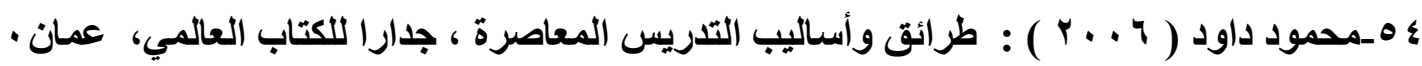

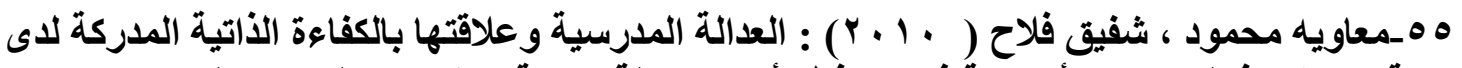

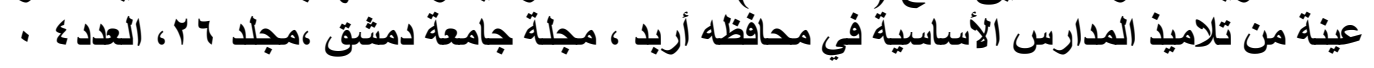

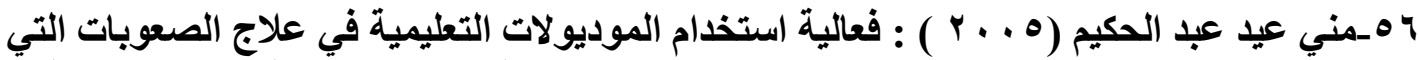

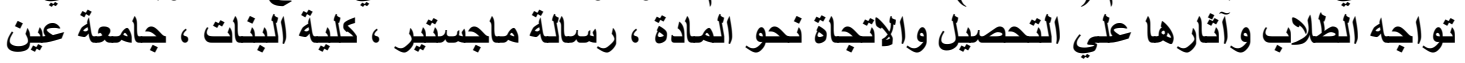
شمس

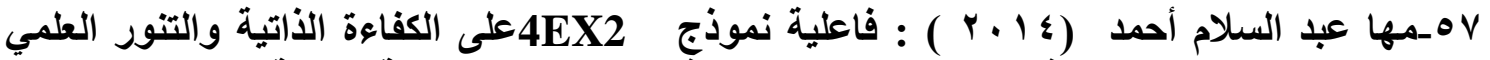

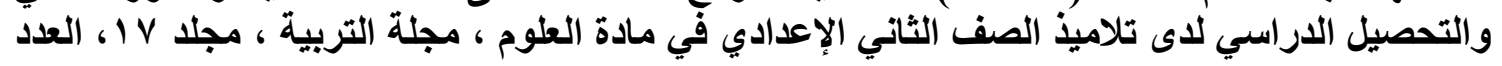

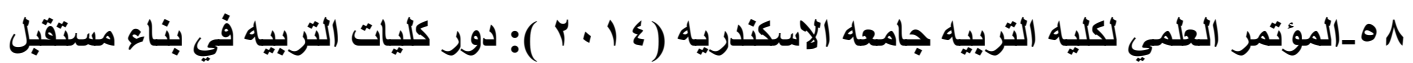

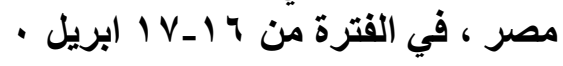

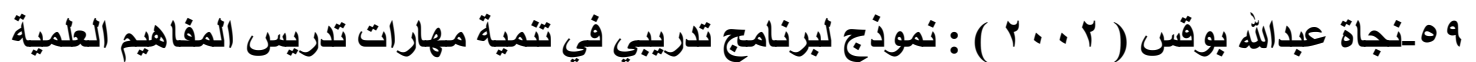

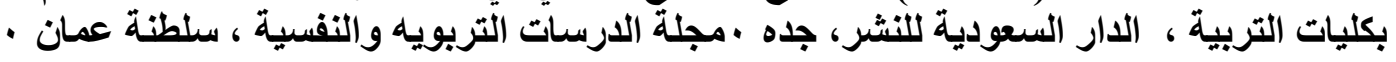

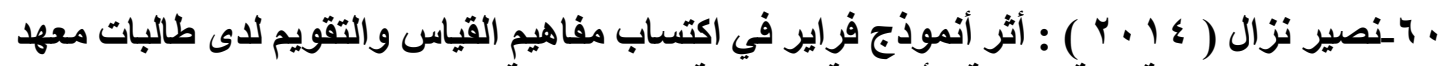

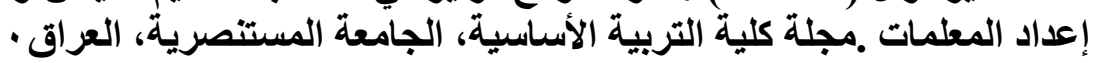

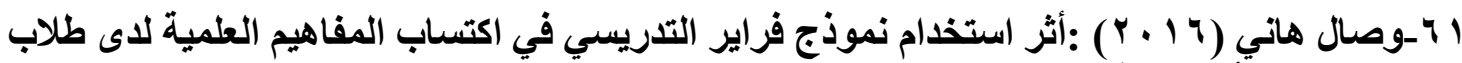

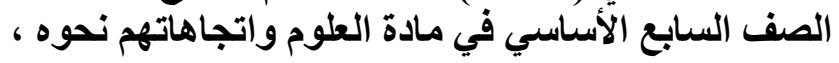

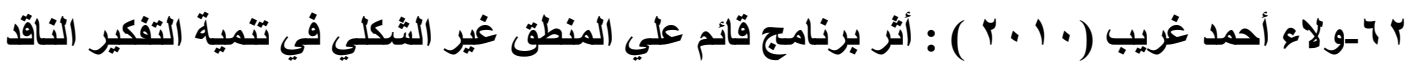

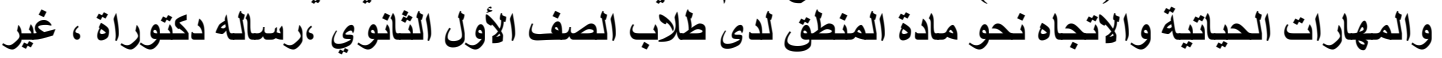

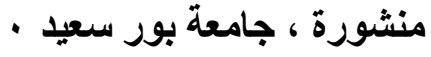

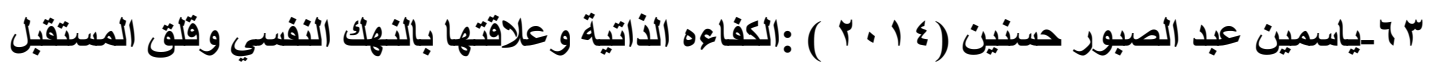

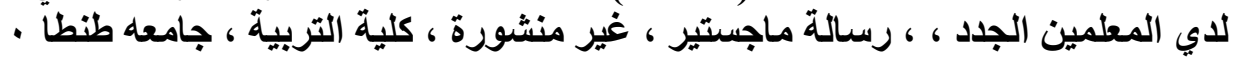

المراجع الاجنبيه

59-Bandura, A. (1997): Self - efficacy. The exercise of control .Stand ford university New York: W. H. Freeman and company

60-Bandura, A (2007): Much ado over Afaulty conception of perceive4 dselfEfficacy Grounded in Faculty Experimentation. Journal of social and clinical psychology

61-Brassell, D. (2011): Dare to Differentiate Vocabulary Strategies. New York, the Guilford press 


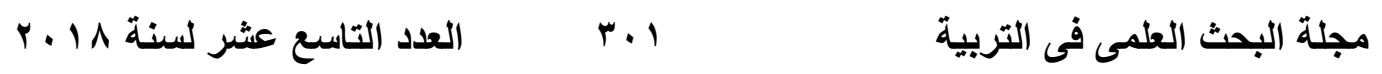

62- Dale.W.(2002): Self - efficacy.Stand ford university New York :W. H. Freeman and company

63-ILTer,(2015):The investigation of The effects of Frayer model on vocabulary knowledge in social studies.Elementary Educationa,online

64-Kimberly,S.C(2004) :Replication results for rural middle school, students ,Paper presented at the April Annual meeting of the American Educational Research Association,San Diego,CA,AEL.

65-Nahampun, E.E., \& Sibarani, B. (2014): The effect of using Frayer model on students' vocabulary mastery. General Journal of Applied Linguistics of FBS Unimed,.

66-Novak, J. and Canas, A. (2007): Theoretical origins of concept maps, how to construct them, and uses in Education. Reflecting Education. V. 3 (1): pp. 29- 42

67-Pajores,F.(2000) : Against the odds:Self-efficacy beliefs of women in mathematical ,scientific and technological careers . American Education Research Journal, vol.37,

68-Palmer,D. (2006): Durability of changes in Self Efficacy of preservice primary teachers. International Journal of Science Education, 28,

Reiss, J. (2012): 120th Content Strategies for English Language Learners.

Boston, Pearson Education, Inc

69-Zimmerman, B. (2000): Self-efficacy: An essential motive to learn Contemporary Educational Psychology, 25(1), 82-91.. 
العدد التاسع عشر لسنة 1 1 ـ r

$r \cdot r$

مجلة البحث العلمى فى التربية 